\title{
Urban productivity and affordable rental housing supply in Australian cities and regions
}

Authored by

Nicole Gurran, The University of Sydney

Kath Hulse, Swinburne University

Jago Dodson, RMIT

Madeleine Pill, The University of Sydney

Robyn Dowling, The University of Sydney

Margaret Reynolds, Swinburne University

Sophia Maalsen, The University of Sydney

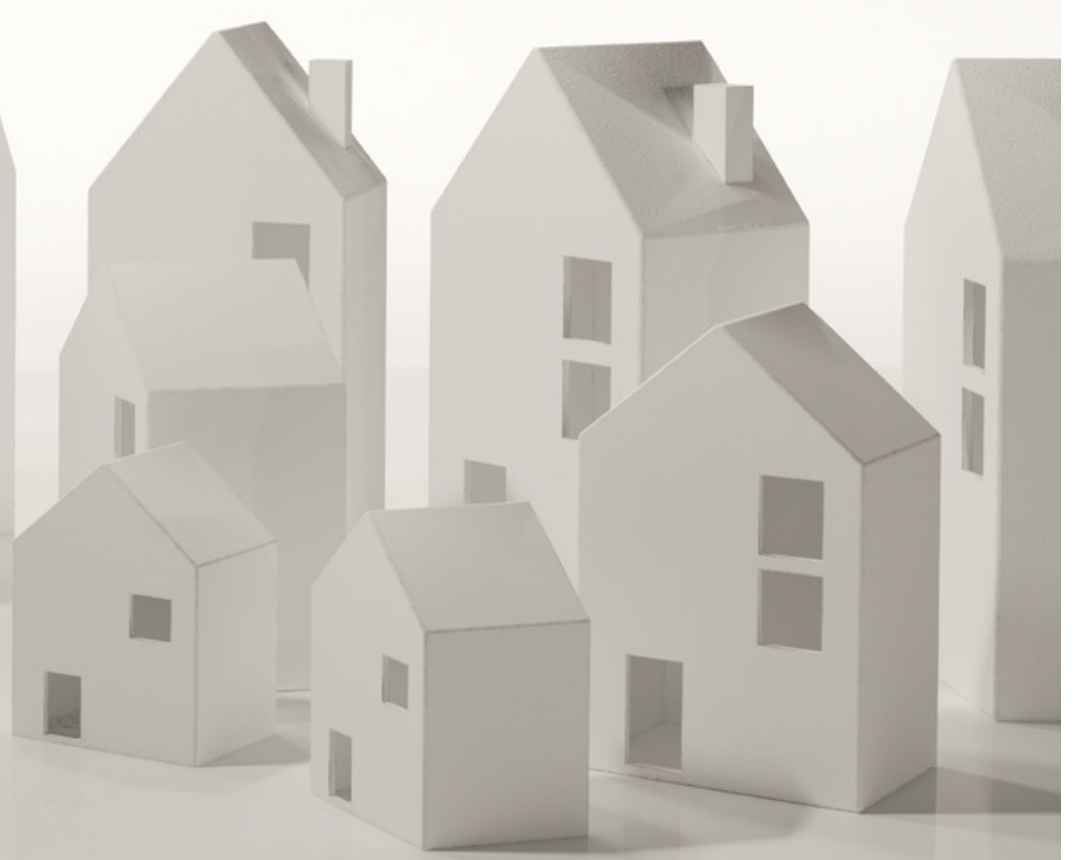

Publication Date March 2020

DOI 10.18408/ahuri7320001 


\section{Title}

Urban productivity and affordable rental housing supply in Australian cities and regions

\section{Authors}

Nicole Gurran, The University of Sydney

Kath Hulse, Swinburne University

Jago Dodson, RMIT

Madeleine Pill, The University of Sydney

Robyn Dowling, The University of Sydney

Margaret Reynolds, Swinburne University

Sophia Maalsen, The University of Sydney

\section{ISBN}

978-1-922498-20-5

\section{Key words}

Affordable rental housing, productivity, cities, employment participation, low-income renters, commuting, digital innovation and cities, regional development, city deals.

\section{Series}

AHURI Final Report

\section{Number}

353

\section{ISSN}

1834-7223

\section{Publisher}

Australian Housing and Urban Research Institute Limited Melbourne, Australia

DOI

10.18408/ahuri7320001

\section{Format}

PDF, online only

URL

https://www.ahuri.edu.au/research/final-reports/353

\section{Recommended citation}

Gurran, N., Hulse, K., Dodson, J., Pill, M., Dowling, R., Reynolds, M. and Maalsen, S. (2021) Urban productivity and affordable rental housing supply in Australian cities and regions, AHURI Final Report No. 353, Australian Housing and Urban Research Institute Limited, Melbourne, https://www.ahuri.edu.au/ research/final-reports/353, doi: 10.18408/ahuri7320001.

\section{Related reports and documents}

Hulse, K., Reynolds, M., Nygaard, C., Parkinson, S. and Yates, J. (2019) The supply of affordable private rental housing in Australian cities: short-term and longer-term changes, AHURI Final Report No. 323, Australian Housing and Urban Research Institute Limited, Melbourne, https://www.ahuri.edu.au/ research/final-reports/323, doi:10.18408/ahuri-5120101.

Pill, M., Gurran, N., Gilbert, C., Phibbs, P. (2020) Strategic planning, 'city deals' and affordable housing, AHURI Final Report No. 331, Australian Housing and Urban Research Institute Limited, Melbourne, https://www.ahuri.edu.au/research/finalreports/331, doi:10.18408/ahuri-7320301.

Dowling, R., Maalsen, S., Emmanuel, L., Wolifson, P. (2020) Affordable housing in innovation-led employment strategies, AHURI Final Report No. 333, Australian Housing and Urban Research Institute Limited, Melbourne, https://www. ahuri.edu.au/research/final-reports/333, doi:10.18408/ ahuri-7320401.

Dodson, J., Li, T. Taylor, E. and Goldie, X. (2020) Commuting burden and housing affordability for low-income renters, AHURI Final Report No. 335, Australian Housing and Urban Research Institute Limited, Melbourne, https://www. ahuri.edu.au/research/final-reports/335, doi:10.18408/ ahuri5320201.

\section{AHURI}

AHURI is a national independent research network with an expert not-for-profit research management company, AHURI Limited, at its centre.

AHURI's mission is to deliver high quality research that influences policy development and practice change to improve the housing and urban environments of all Australians.

Using high quality, independent evidence and through active, managed engagement, AHURI works to inform the policies and practices of governments and the housing and urban development industries, and stimulate debate in the broader Australian community.

AHURI undertakes evidence-based policy development on range of priority policy topics that are of interest to our audience groups, including housing and labour markets, urban growth and renewal, planning and infrastructure development, housing supply and affordability, homelessness, economic productivity, and social cohesion and wellbeing.

\section{Acknowledgements}

This material was produced with funding from the Australian Government and state and territory governments. AHURI Limited gratefully acknowledges the financial and other support it has received from these governments, without which this work would not have been possible.

We acknowledge the collaboration and input of wider Inquiry Project team members including Christian Nygaard, Sharon Parkinson, Judith Yates, Catherine Gilbert, Yuting Zhang, and Caitlin Buckle.

AHURI Limited also gratefully acknowledges the contributions, both financial and

in-kind, of its university research partners who have helped make the completion of this material possible.

\section{Disclaimer}

The opinions in this report reflect the views of the authors and do not necessarily reflect those of AHURI Limited, its Board, its funding organisations or Inquiry panel members. No responsibility is accepted by AHURI Limited, its Board or funders for the accuracy or omission of any statement, opinion, advice or information in this publication.

\section{AHURI journal}

AHURI Final Report journal series is a refereed series presenting the results of original research to a diverse readership of policy makers, researchers and practitioners.

\section{Peer review statement}

An objective assessment of reports published in the AHURI journal series by carefully selected experts in the field ensures that material published is of the highest quality. The AHURI journa series employs a double-blind peer review of the full report, where anonymity is strictly observed between authors and referees.

\section{Copyright}

(C) Australian Housing and Urban Research Institute Limited 2021

This work is licensed under a Creative Commons Attribution-NonCommercial 4.0 International License, see http://creativecommons.org/licenses/by-nc/4.0/. 


\section{Inquiry panel members}

Each AHURI Inquiry is supported by a panel of experts drawn from the research, policy and practice communities.

The Inquiry Panel are to provide guidance on ways to maximize the policy relevance of the research and draw together the research findings to address the key policy implications of the research. Panel members for this Inquiry:

- Carla Adami, Commonwealth Treasury

- Troy Daly, Greater Sydney Commission

- Bronwen Clark, National Growth Areas Alliance

- Richard Wood, Department of Infrastructure, Cities Division

- Llewellyn Reynders, Infrastructure Victoria

- Sidesh Naikar, Department of Social Services, Australian Government

- Craig Downsbourough, Department of Infrastructure, Transport, Cities and Regional Development, Cities Policy, Coordination \& International, Australian Government

- Margorie Ferguson, MF Plan Plus

- Bronwen Clark, National Growth Areas Alliance

- Mark Wall, Queensland Housing and Public Works 


\section{Contents}

List of tables $\quad v$

List of figures $\quad v$

Acronyms and abbreviations used in this report vi

Executive summary 1

1. Introduction

1.1 Inquiry framework: Urban productivity and housing

1.2 Inquiry questions

1.3 Policy context and existing evidence

1.3.1 Urban productivity and housing in Australia

10

1.3.2 The changing supply of affordable and available private rental housing

1.3.3 Job accessibility, commuting costs, and urban productivity

1.3.4 Strategic spatial planning and funding interventions

1.3.5 Smart city and innovation-led employment strategies

1.3.6 Summary and preliminary implications for policy development

1.4 Research methods

1.4.1 Case study selection

1.4.2 Examining changes in the supply of

affordable rental housing in Australian cities, 2011-1616

1.4.3 Examining affordable rental housing, spatial employment structures, commuting cost burdens and urban productivity

1.4.4 Investigating existing and potential strategic planning and funding interventions for making affordable rental housing more accessible to employment opportunities

1.4.5 Examining smart cities, innovation economies, and affordable rental housing

1.5 Summary of Inquiry research approach, data sources, and the structure of this report

2. The changing supply of affordable and available private rental housing

2.1 Existing research on affordable private rental supply

2.2 Structural changes in the Australian private rental sector

2.2.1 National level changes in the Australian PRS

2.2.2 Increasing shortages of affordable and available private rental housing for low-income (Q2) households in urban Australia
2.3 Affordable and available private rental supply for Q2 households in capital and satellite cities

2.3.1 Capital cities 23

2.3.2 Regions within capital cities 24

2.4 Summary and implications for policy development

3. Housing stress, commute burdens, and employment access

3.1 Urban productivity, labour markets, and affordable rental housing

3.2 The location of employment

opportunities relative to affordable rental housing in Sydney and Melbourne

3.3 Do Q2 workers have longer commutes to work than other groups?

3.4 Q2 workers in satellite cities

3.5 Patterns of job concentration and dispersion 33

3.6 How does access to affordable rental housing intersect with the employment status of Q2 households?

3.6.1 Employment status of private renter households by quintile

3.6.2 Employment status and rental

affordability status

3.6.3 Q2 private renter households by employment status and rental affordability outcomes: Sydney, Melbourne and satellite cities, 2016

3.7 Summary and policy implications

4. Strategic planning, place-based funding, and digital innovation

4.1 Australian strategic planning frameworks

4.1.1 Planning frameworks and affordable rental supply

4.1.2 Improving connectivity to employment opportunities, and stimulating growth near areas of existing affordable housing supply

4.2 Strategic place-based funding interventions 48

4.2.1 Understanding strategic 'place-based' funding interventions

4.2.2 Place-based deals in the UK

4.3 Strategic funding interventions in Australia: City Deals in Western Sydney and Geelong

4.3.1 Supporting firms to invest in priority locations or in satellite cities 
4.4.2 Innovation economies and affordable rental housing: the perspectives of firms

4.5 Summary and implications for policy development

5. Policy development options 55

5.1 Summary of key findings

5.2.1 Increasing affordable rental housing near key employment areas

5.2.2 Targeting locations for new affordable rental housing supply

5.2.3 'Concentrated' decentralised

employment opportunities, by leveraging strategic place-based funding interventions and digital innovation

5.2.4 Improving the accessibility of outer suburban and satellite city housing markets 60

5.3 Limitations of the Inquiry and priorities for further research 


\section{List of tables}

Table 1: Summary of Inquiry research project questions, methods, and data sources

Table 2: Spatial concentration of jobs by industry (dissimilarity index), Sydney, Melbourne and satellite cities, 2016

Table 3: Employment and socio-demographic status for Q1, Q2 and Q3 households, 2016,

Australia 38

Table 4: Review of capital city strategic planning frameworks

Table 5: Strategic place-based funding interventions, international models 48

Table 6: Place-based deals and strategic funding mechanisms in the UK

Table 7: Selected international and Australian models of innovation districts

Table 8: Summary of potential policy options and interventions

\section{List of figures}

Figure 1: Conceptualising relationships between affordable rental housing, employment, connectivity, and urban productivity

Figure 2: Per cent change in the number of households by housing tenure, 2011-16 and 2006-16, Australia

Figure 3: Shortage of affordable and available rentals for Q2 PRS households in metropolitan regions, 2006, 2011, 2016

Figure 4: Changes in the supply of housing affordable to Q2 PRS households in inner, middle and outer regions of Melbourne and Sydney, 2006, 2016

Figure 5: Shortage of affordable and available dwellings for Q2 private renter households, Sydney and Melbourne (inner, middle, outer) and selected satellite cities, 2006, 2011, 2016

Figure 6: Employment density and private rental housing affordable to Q2 households 2016, Greater Sydney

Figure 7: Employment density and private rental housing affordable to Q2 households 2016, Greater Melbourne

Figure 8: Journey to work trips for Q2 renters in Sydney with high commuting burdens

Figure 9: Journey to work trips for Q2 renter workers in Melbourne with high commuting burdens32

Figure 10: Geography of occupations and affordable rental housing supply, Greater Sydney

Figure 11: Geography of occupations and affordable rental housing supply, Greater Melbourne

Figure 12: Geography of occupations and affordable rental housing supply, Wollongong 36

Figure 13: Geography of occupations and affordable rental housing supply, Geelong

Figure 14: Employment status of 'all' renter households and Q2 renter households living in affordable/unaffordable rental housing, Australia, 2016

Figure 15: Q2 PRS household employment status in affordable and unaffordable rental, Sydney and satellite cities

Figure 16: Q2 PRS household employment status Melbourne and satellite city

Figure 17: Employment density and potential affordable rental housing supply, Sydney

Figure 18: Employment density and potential affordable rental supply, Melbourne 


\section{Acronyms and abbreviations used in this report}

\begin{tabular}{|c|c|}
\hline ABS & Australian Bureau of Statistics \\
\hline ACT & Australian Capital Territory \\
\hline AUS & Australia \\
\hline AHURI & Australian Housing and Urban Research Institute Limited \\
\hline CBD & central business district \\
\hline DIRD & Department of Infrastructure and Regional Development (Australia) \\
\hline GFC & Global Financial Crisis \\
\hline GDP & gross domestic product \\
\hline ICT & Information and Communication Technology \\
\hline MCU & Major Cities Unit \\
\hline NSW & New South Wales \\
\hline NT & Northern Territory \\
\hline OECD & Organisation for Economic Cooperation and Development \\
\hline PRS & private rental sector \\
\hline Q1, Q2, Q3 & Quintile 1, 2 and 3 of national gross household income distribution \\
\hline QLD & Queensland \\
\hline SA & South Australia \\
\hline TAS & Tasmania \\
\hline UNSW & University of New South Wales \\
\hline UK & United Kingdom \\
\hline US & United States \\
\hline VIC & Victoria \\
\hline WA & Western Australia \\
\hline
\end{tabular}




\section{Executive summary}

\section{Key points}

This Inquiry examined changes in the supply of private rental housing and the implications for strategic policy interventions geared towards improving urban productivity.

- Low-income (Q2') households are a critical sector of the workforce, but increasingly struggle to find affordable rental housing near employment centres of Australia's major urban areas.

- Over two decades, the nation's shortage of affordable dwellings available for Q2 households in the private rental sector has grown to 173,000, with the most extreme shortage in Sydney (60,000 dwellings), where 71 per cent of all Q2 private rental households pay unaffordable rent.

- The shortage is most acute in inner and middle ring areas which offer higher accessibility to greater concentrations of employment opportunities. Consequently, Q2 renters are either enduring affordability stress, commuting burdens, or both in order to access employment opportunities. There is lower employment participation by Q2 households who live in outer suburban locations of both Sydney and Melbourne, although the extent to which this reflects household trade-offs is unclear.

- To address this, the Inquiry identified three primary policy development options: increasing affordable rental housing near key employment areas; improving accessibility and connectivity to outer suburban and satellite city housing markets via strategic investment in transport and communications infrastructure; and 'concentrated decentralisation' -fostering new employment clusters through strategic place-based funding interventions and digital innovation.

1 This report uses quintiles which split the national gross household income distribution into five equal parts. Quintile 1 refers to household incomes in the bottom 20 per cent of that distribution (described as Q1 or very low-income); Quintile 2 refers to household incomes between 21 and 40 per cent of that distribution (Q2 or low-income) and Quintile 3 refers to household incomes between 41 and 60 per cent of that distribution (Q3 or moderate income). 
- Providing more affordable rental opportunities in locations offering high access to employment would benefit Q2 households currently living in housing stress and support long term labour market sustainability. In particular, policies to increase affordable supply in middle suburbs through new development incorporating lower cost rental housing would assist employment participation and reduce housing stress of Q2 households.

- Place-based funding interventions such as 'City Deals' have emerged as important models for catalysing new development, including housing, through strategic investment. Growing use of these models in Australian cities represents an opportunity to link transport and infrastructure investment to affordable housing in accessible locations.

- Digital and innovation sectors can play an important role in urban productivity by supporting new work practices such as telecommuting, and potentially by creating economic opportunities in locations with lower cost housing, such as the outer suburbs of major cities and in satellite or regional cities. Planned innovation precincts which cluster around 'anchor institutions' like universities can achieve agglomeration benefits, particularly if supported by high quality transport and communications infrastructure. However, mechanisms to preserve affordability and ensure that new affordable rental housing is created as part of new development, are critical.

\section{Key findings}

This Inquiry examined relationships between urban productivity and affordable rental housing, focusing particularly on the location and availability (shortage/surplus) of affordable rental housing relative to employment and labour market indicators, in capital cities and satellite cities.

\footnotetext{
There has been extensive economic research on factors thought to drive urban productivity, with spatial agglomeration of firms and services known to enhance productivity through positive knowledge 'spillovers' (Glaeser and Gottlieb 2009; Puga 2010). This can be seen in Australia where economic activity and gross domestic product (GDP) concentrates in the major cities and particularly Sydney and Melbourne. However, urban agglomeration is also associated with disadvantages - such as traffic congestion or higher housing costs (Zheng 2001; Glaeser and Gyourko 2018), requiring spatial policy to balance economic productivity goals with wider social and environmenta considerations. Further, high housing costs and traffic congestion can themselves become a drain on urban productivity, as investigated in this Inquiry.
}

To examine potential policy development options to balance these key tensions, the Inquiry investigated strategic place-based funding interventions such as 'City Deals', which have become an increasingly important model in Australia and internationally. The Inquiry also examined the potential role of digital innovation to support new economic opportunities and geographies of employment. 


\section{The supply of affordable rental housing}

The empirical research collected to inform the Inquiry provides strong evidence of what appears to be structural rather than cyclical change in the Australian housing system (Hulse, Reynolds et al. 2019). In particular, the private rental sector (PRS) has been growing since 2001 at twice the rate of all households and at an accelerating rate in the 10 years from 2006 to 2016.

Current policy settings - including capital city planning frameworks with ambitious new housing targets - have facilitated this increase in aggregate housing supply. However, barriers to first home ownership, particularly in the capital cities, have contributed to important structural changes in the private rental sector, namely:

1. an increase in dwellings with mid-market rents, and

2. an increase in PRS households at mid-higher income levels (Hulse, Reynolds et al. 2019).

At the same time, reduced availability of social housing for low-income (Q2) earners, and increased demand for rental housing by Q3 (moderate income) households in major cities, means that Q2 income households are facing increasing affordability burdens in seeking accommodation accessible to the majority of employment opportunities.

These findings have serious implications for urban productivity. Low-income (Q2) rental households who are strongly engaged in the labour market are sacrificing housing affordability for access to employment opportunities. Q2 workers who do not live in inner areas of large cities tend to be at the lower end of the Q2 income scale, with some enduring high commuting burdens to access central business district (CBD) employment. There is lower overall employment participation by Q2 households living in outer suburban locations of Sydney and Melbourne.

\section{Increasing the supply of rental housing affordable and available to lower income households}

There is ongoing opportunity to increase affordable housing within inner and middle ring areas. As outlined, both Melbourne and Sydney offer significant capacity for increased housing supply even under current planning rules. The findings of this Inquiry suggest, however, that complex market barriers (e.g. underlying land values and the complexities of site acquisition, amalgamation, and remediation) rather than zoning or development controls are preventing take up of these opportunities. Given that the market is not currently making full use of available planning capacity, planning system interventions that seek to stimulate new supply by further 'upzoning' residential areas will have limited success. Additional interventions are likely needed to catalyse new and affordable housing growth in these locations.

\section{Catalysing new economic opportunities, while preserving affordability}

Our review of strategic policy interventions and funding 'deals' used internationally and increasingly in Australia suggests that collaborative, place-based interventions offer opportunities to catalyse new growth through transformative infrastructure or other investment. These represent opportunities for outer suburban regions of metropolitan centres, as well as satellite and regional cities, but specific strategies are needed to ensure that affordable housing is created and/or preserved.

Finally, this Inquiry has provided 'first cut' evidence on the role of affordable rental housing in the context of smart cities, with the potential for digital innovation and technology industries to support economic growth in suburban and regional areas increasingly recognised in Australia. The findings suggest firstly, that access to secure and affordable housing is an important precondition for digital startups; and secondly, that strategies to foster innovation firms may be effective in high amenity satellite cities ${ }^{2}$ where existing skilled workers already reside and others may be attracted to relocate. However, strategies for fostering digital innovation industry precincts accessible to existing and future affordable rental housing supply remain unexplored.

2 Satellite cities refer to major regional cities which have their own infrastructure and employment base but which also offer commuting options, such as Wollongong (NSW) and Geelong (Victoria). 


\section{Managing the contradictions of urban agglomeration}

The findings of this Inquiry raise policy tensions in economic and spatial planning. As noted, urban agglomeration is widely understood to generate productivity gains from shared infrastructure, deep labour pools and knowledge spillovers. There is evidence from the research undertaken in this Inquiry that in some locations the intense concentration of employment in city centres is enabling productivity, yet also spurring house price inflation by increasing demand and land values in proximate locations with high accessibility to employment centres.

This process has implications for lower income households such as Q2s who are pushed out by rising rents to less job-accessible locations, or remain and experience housing stress. There is not yet clear evidence in Australia of the relative productivity benefits and costs of intense urban economic agglomeration. Thus, a clear policy tension arises-addressing housing affordability through supply of stock in less accessible locations, and risking productivity losses from reduced agglomeration, or increasing affordable housing supply in employment concentrated areas, with associated costs.

This policy tension can also be viewed from the perspective of dispersed suburban areas with relatively few high-value jobs, but which offer housing that is affordable to Q2 renters. Policy is questioning the advantages of increasing employment in such zones, recognising longstanding debates in regional economics about the merits of place-based intervention to address spatial disadvantage (Neumark and Simpson 2015).

Despite these economic debates, recent metropolitan planning in Australia has embraced the notion of smaller, connected urban agglomerations, each with their own internal labour market and housing market dynamics, albeit with differing compositions. This is demonstrated by the 20-minute or 30-minute neighbourhood concepts being developed in Melbourne and Sydney, and in Australia's Smart Cities Plan (Department of the Prime Minister and Cabinet 2016). These policies seek to mix employment and housing with infrastructure in key suburban nodes, in part to avoid long-distance travel to remote worksites. Similarly, place-based funding interventions have emerged internationally and in Australia as important policy tools to stimulate economic growth in new locations, as examined in this Inquiry.

Thus, in investigating the relationships between urban productivity and affordable rental housing in this Inquiry, we recognise the need for further and ongoing research to quantify potential economic benefits or trade-offs associated with spatial, housing, or employment strategies.

\section{Policy development options}

The following policy development options were identified through this Inquiry.

\section{Increasing affordable rental housing near key employment areas}

This strategy recognises that central city areas will continue to attract and absorb higher value, productive sectors of employment and wider jobs growth, although the extent to which this will continue in the post COVID-19 era remains unclear. It is essential to mobilise more policy levers and resources towards new affordable rental supply in these central areas, with access and eligibility restrictions to ensure that Q2 households are able to access this housing. The analysis of land availability and current rental prices suggests that market-based housing delivery is unlikely to attain affordability objectives at a scale that would have substantial impact on the Q2 cohort.

Further strategies include using well located public land for affordable rental housing development; and requiring affordable homes to be included as part of all residential projects. Reviewed in this Inquiry, the City Deal framework provides a model for investing in catalytic infrastructure, which may include a direct investment in affordable housing, while leveraging local responses. These local responses might also include land dedication by councils as well as planning requirements for affordable rental housing in major new developments (now possible in NSW and SA under state planning legislation). These requirements should be 'matched to market' so could include mechanisms to maintain affordable home ownership for lower and moderate income earners (as operating in South Australia); or to ensure that a proportion of new dwellings is available to lower income households at an affordable rent. 
Density bonuses are an opportunity for encouraging projects in well located areas to include affordable rental housing in exchange for increased development potential, as occurs in Sydney, where developers can achieve additional floorspace in return for ensuring that a proportion of dwelling units are rented to eligible households at a 20 per cent market discount for at least 10 years.

\section{Concentrated decentralisation-fostering new employment clusters through strategic place-based funding interventions and digital innovation}

The objective of this approach is to increase employment opportunities, including skilled employment, in selected locations that are undersupplied with jobs. In these areas, housing markets are typically more affordable, but poor job accessibility means that low-income workers usually have a long commute to work or accept lower wage rates and/or workforce participation.

Given broad scholarly agreement that concentrated employment clusters enhance productivity through agglomeration effects, any decentralisation of employment should be concentrated into nodes rather than dispersed. Such nodes should also be linked by high quality transport networks.

Demonstrated internationally and used increasingly in Australia, strategic policy interventions and place-based funding 'deals' can catalyse new economic opportunities in targeted locations, often through infrastructure and transport upgrading in areas such as Western Sydney, which are currently undersupplied with jobs. However, explicit levers to preserve and create rental housing affordable to Q2 rental households are needed in these higher value capital city markets.

Land use planning frameworks may support the development of innovation precincts, through models such as 'live/work' zones; while strategic place-based funding interventions could prioritise connectivity (physical and digital) to enable new firms to operate outside established central city areas and improve working from home options. Also, amenity qualities - local cycle/pedestrian networks, distinctive and sustainable urban design - are known to attract digital entrepreneurs and their staff. Policy initiatives linking housing and smart city initiatives are not yet embedded in Australian metropolitan planning, however models emerging in Newcastle, Adelaide, and Northern NSW provide a starting point to emulate. It is likely that experiences of working from home during the COVID-19 pandemic will fast forward some of these changes.

\section{Improving the accessibility of outer suburban and satellite city housing markets}

This approach aims to better connect locations of existing jobs and housing, through strategic investment in transport infrastructure.

Again, place-based funding interventions are an ideal vehicle for delivering transformative infrastructure investments such as (light) rail and bus networks or transit corridors, and for leveraging commensurate commitments from recipient state or local jurisdictions. Core requirements include the need for state and local governments to enact affordable housing provisions in areas targeted by the infrastructure investment. Affordable housing provisions are necessary to preserve affordability and ensure that new development catalysed by improved transport accessibility contributes to affordable rental supply, targeted to lower income earners.

Value capture-a levy on development or property which directly benefits from the investment through increased land values or business revenues - provides one model for governments to recoup some of the costs of providing infrastructure. The value capture revenue stream can help finance the project and/or support additional affordable housing provision.

This Inquiry finds some evidence of housing market driven decentralisation, particularly from Sydney to satellite areas such as Wollongong and the NSW Central Coast. Strategies to support this process include investment to deliver better transport and digital connectivity, enabling firms to establish in these locations, which already accommodate skilled workers and may attract more workers by high amenity and lower housing costs. Digital connectivity would also enhance opportunities for working from home, heightened by the COVID-19 pandemic. 
However, it is unlikely that growth in satellite cities will substantively impact on Sydney and Melbourne's housing markets, at least in the short to medium term, given the disparities of scale between the major and satellite cities. Thus, developing new strategies to increase the supply of affordable rental housing for Q2 households in accessible locations is critical.

\section{The study}

This report brings together key findings from the AHURI Inquiry into urban productivity and affordable rental housing supply in Australian cities and regions. The Inquiry was conducted through four discrete but intersecting research projects, extending previous AHURI work (e.g. Gurran, Phibbs et al. 2015; Ong, Wood et al. 2017) to focus on the role of affordable private rental housing in Australian urban and regional economies. To this end, it brings together analysis of repeated, cross sectional data on the private rental housing supply affordable to lower income households, relative to the geography of employment opportunities, labour market participation, and commuting patterns. The Inquiry also examined existing and potential strategic planning frameworks and funding interventions which support urban and regional economies by improving accessibility to affordable homes and employment opportunities, including new opportunities in digital and innovation-led firms.

This Final Report explains the conceptual framework for the Inquiry, outlines the range of methodologies and data sources applied, and presents key findings, highlighting policy implications. Readers seeking more detail on the underlying studies which inform this Inquiry can access individual project reports at https://www.ahuri.edu.au/ research/research-in-progress/ahuri-inquiries/urban-productivity-and-affordable-rental-housing-supply. 


\section{Introduction}

- High housing costs are thought to undermine the economic productivity of Australian cities, but empirical evidence explaining relationships between housing affordability and urban economies is limited.

- This Inquiry extends previous AHURI research to focus on the role of affordable private rental housing in relation to employment opportunities, labour market participation and commuting; as well as existing and potential strategic interventions.

- Four interlinked projects address discrete empirical and policy relevant questions to build the evidence base for this Inquiry.

- This Final Report sets out the Inquiry framework, research methods, key findings, and implications for policy development. 
There has been widespread concern about high housing costs in Australia's major cities, and wider implications for economic productivity and social inclusion. This Inquiry addresses these themes. Building on previous AHURI work, the Inquiry focused specifically on the role of the private rental sector in relation to the geography of employment opportunities, labour market participation, and commuting patterns of lower income earners. The Inquiry also examined existing and potential strategic planning frameworks and funding interventions which support urban and regional economies by improving accessibility to affordable homes and employment opportunities, including new opportunities in digital and innovation-led firms.

This Final Report explains the conceptual framework for the Inquiry, outlines the range of methodologies and data sources applied, and presents key findings, highlighting implications for policy. Readers seeking more detail on the underlying studies which inform this Inquiry can access individual project reports at https://www.ahuri.edu. au/research/research-in-progress/ahuri-inquiries/urban-productivity-and-affordable-rental-housing-supply.

\subsection{Inquiry framework: Urban productivity and housing}

The relationships between productivity and housing are complex. Productivity - the ratio of economic outputs relative to labour or capital inputs - is known to improve in cities through agglomeration-the clustering of activities, skilled labour, and the resulting knowledge 'spillovers' which tend to occur in cities and particular locations within them (Ciccone and Hall 1993; Rosenthal and Strange 2004; Puga 2010). However, this process of agglomeration is associated with increased housing demand, as workers relocate to be close to employment opportunities (Glaeser and Gottlieb 2009).

Rental housing can support this agglomeration process by enabling workers to move to job rich regions (OECD 2011). In particular, it is the private rental sector which provides greatest flexibility in enabling a match between housing and jobs, due to ease of mobility and lower transaction costs relative to other types of housing tenure (home ownership and social rental) (Whelan and Parkinson 2017). Expensive housing markets are thought to constrain this process, by reducing the potential for workers to relocate. This is a particular problem when cities encounter housing supply constraints-which typically occurs when larger conurbations reach growth thresholds and are constrained by natural amenities (Saiz 2010).

Higher income earners in skilled occupations will attract a sufficient wage premium to compensate for higher housing costs (and in turn contribute to housing demand). However, lower and moderate income workers who also play critical roles in urban economies are more likely to experience housing stress (exceeding $30 \%$ of their income on housing costs) in these markets. Thus, increasing the supply of affordable housing, and particularly rental housing that is affordable to low and moderate income earners, is an important strategy to support economic growth in areas of high employment opportunity.

Further, while acknowledging the important economic benefits of urban agglomeration, diseconomies associated with congestion and spatial inequality also arise. Strategic investment in transport infrastructure to improve connections between employment and lower cost housing opportunities may support urban productivity. Similarly, strategies to support new economic development in areas where housing costs are lower may offer regional productivity gains if this can be achieved without losing the benefits of agglomeration.

Therefore, in this Inquiry we consider opportunities to improve urban productivity in relation to:

1. the location and availability of rental housing, affordable to low-income households relative to the location of employment centres;

2. the time and costs associated with work commutes for lower income renters;

3. potential implications for employment opportunities and workforce participation by low-income renters; and,

4. potential strategies to improve the supply of affordable rental housing accessible to existing and new employment opportunities, including through strategic funding interventions and digital innovation. 
This conceptual framework (summarised in Figure 1) provided a basis for examining evidence about the location of private rental supply affordable and available for lower income earners; the geography of employment opportunities and labour market participation; and the journey to work. We recognise that this is a necessary simplification of complex urban and economic processes with multiple and intricate feedback loops. Often these are self-reinforcing - such as increased earnings and jobs growth from productivity gains — which in turn may impact on housing demand and increase land prices but also improve affordability for workers whose incomes rise. Further, the range of external factors which influence demand and supply of housing (such as the cost of finance) are not shown here.

Without dismissing these complexities, our focus in this Inquiry Final Report is on potential strategic policy interventions to increase affordable housing in locations near major employment centres; improve accessibility between existing affordable rental supply and these employment centres; and/or support new job creation near areas offering more affordable rental housing supply, such as outer suburban areas and satellite cities located close to metropolitan regions.

Rental housing for Q2 income households is a particular focus for this Inquiry, because these households are most likely to be in lower paid or lower skilled jobs, and most likely to have restricted options for locations to rent or buy. The 2017-18 Australian Bureau of Statistics (ABS) Survey of Income and Housing (latest available) calculates Q2 households as earning between $\$ 749-\$ 1,337$ gross per week (from $\$ 38,897$ to $\$ 69,524$ per annum) (ABS 2019). This is gross income from all sources summed for all household members. A feature of Q2 households is that most have one full-time or part-time income earner (see Section 3.6.1). There is potential in those Q2 households with two or more adults for additional members to earn income from paid work, increasing the supply of labour. While in theory private renting provides the greatest flexibility in matching people and jobs, the location of affordable rental housing may present barriers to further economic participation. By contrast, Q1 households are less likely to be in the workforce at all, although some have the potential to re-enter the workforce.

Figure 1: Conceptualising relationships between affordable rental housing, employment, connectivity, and urban productivity

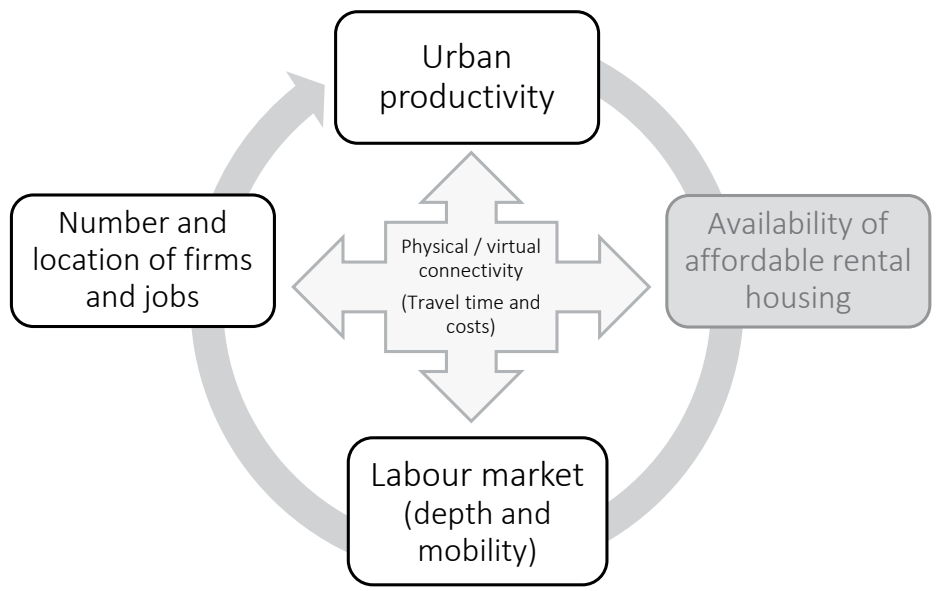

Source: Authors.

In examining the relationships between affordable rental housing, employment connectivity, and urban productivity, the Inquiry particularly focused on the location and availability (shortage/surplus) of affordable rental housing relative to employment and labour market indicators, in capital cities and satellite cities. Capital cities continue to absorb the majority of Australia's employment and population growth, with flow-on implications for housing affordability. Satellite cities are defined in this Inquiry as cities/towns located in proximity to major metropolitan centres. With their own governance arrangements, economic base and labour supply, satellite cities are usually connected by public transport and offer commuting options for residents who want to work in the major metropolitan centre and for firms seeking accessible but lower cost locations. For these reasons satellite cities may offer opportunities for new employment and/or housing growth. 


\subsection{Inquiry questions}

The overarching question for this Inquiry Program was:

How does affordable rental housing supply support labour markets and urban productivity, and what are the implications for strategic funding and planning interventions in metropolitan and non-metropolitan Australia?

Four more detailed questions framed the Inquiry research:

1. How has the supply of affordable and available private rental housing changed in 2011-16 nationally and at a variety of spatial scales and what is the performance of capital cities and satellite cities in providing affordable and available supply for Q2 households in ways that could enhance productivity?

2. How does the changing supply of affordable rental housing for the second lowest income quintile households in Australian cities affect labour force participation including job accessibility and commuting cost burden?

3. How can strategic spatial planning and funding interventions leverage affordable rental housing choices near employment, enhancing urban productivity?

4. What possibilities for affordable housing supply are provided by smart city and innovation-led employment strategies, especially for regional and outer metropolitan areas?

This Final Report draws together and synthesises the key findings from these projects in relation to the overarching Inquiry question.

\subsection{Policy context and existing evidence}

This Inquiry was conducted during a period of national debate about the distribution of population growth, infrastructure deficiencies and capacity in Australia's cities and regions, and the potential to foster new economic opportunities and growth beyond existing employment centres (Infrastructure Australia 2018). Declining housing affordability - and particularly access to affordable private rental housing for lower income workers unable to access home ownership in the major cities-has been an underlying theme in this debate. In the following sections, we outline the research literature relevant to investigating intersections between housing and urban productivity, with specific attention to the private rental market, jobs accessibility, and commuting costs. We include in this review the range of strategic funding interventions emerging internationally to support economic revitalisation and affordable housing supply and the potential for digital innovation firms to foster new opportunities outside existing central city areas.

\subsubsection{Urban productivity and housing in Australia}

As noted, productivity in urban areas is thought to increase due to the concentration of jobs in central locations and the positive flow-on knowledge and labour market 'spillovers' which arise. Australia's economic geography is highly concentrated, with Sydney and Melbourne accounting for around 40 per cent of the population and 43 per cent of national GDP (MCU 2010). Within these cities, the distribution of highly skilled employment sectors (associated with higher labour productivity measures) is traditionally concentrated too, clustered within central business areas. Housing in proximity to these locations is in high demand, and prices and rents are unaffordable to lower income workers.

A number of Australian studies have examined aspects of the relationship between housing and economic productivity (Gurran, Phibbs et al. 2015; van den Nouwelant, Crommelin et al. 2016; Dodson, de Silva et al. 2017). These studies highlighted the need to consider housing more centrally in urban and regional policy (Maclennan, Ong et al. 2015). They draw attention to a growing mismatch between the location of employment opportunities and housing affordable to lower and, increasingly, middle income households, which can contribute to urban congestion (Li, Dodson et al. 2017), and may exert barriers to workforce participation (Gurran, Phibbs et al. 2015). 
Internationally, research on urban productivity has considered housing supply in aggregate-whereby economic and population growth triggers higher house prices (Glaeser, Gyourko et al. 2005; Glaeser, Ponzetto et al. 2014), particularly when new supply is constrained. This (primarily US based) work suggests that higher wages are subsumed in high housing costs rather than supporting wider consumption or investment, and often prescribes urban planning reform and deregulation as a strategy to enable new housing supply to respond to population and wage growth. However, in recent years the housing supply response has been relatively strong in Australian capital cities, possibly enabled by planning reform efforts to enable higher density housing near transport and employment centres, but this has not resolved affordability pressures for lower income households (Ong, Wood et al. 2017). More specific questions around urban productivity and the supply and availability of rental housing for lower income households are largely unexplored in the international literature.

In this Inquiry Final Report we assemble evidence on the relationship between urban productivity and declining affordable rental supply and rental affordability in terms of (a) labour markets (labour market depth, cost of labour); (b) employment participation; and (c) commuting time (as a cost and a productivity drain). Further, we consider existing and potential strategic planning and funding interventions to enhance urban productivity in regions where housing costs are lower, and to increase the supply of affordable rental housing in areas of high job opportunity.

\subsubsection{The changing supply of affordable and available private rental housing}

The supply and location of affordable private rental housing is of critical importance in understanding labour market mobility and employment opportunities in Australia, particularly because the proportion of Australian households occupying private rental housing is growing. The 2017-18 ABS Survey of Income and Housing estimates that 27 per cent of Australian households live in private rental housing, up from 20 per cent in 1997-98). However, there are increasing shortages of dwellings at the lower-rent end of the sector, with the quantum of dwellings affordable to lower income households declining over the last twenty years. These supply shortages are further exacerbated when moderate to higher income households occupy lower rent dwellings, competing with lower income households in the market (Hulse, Reynolds et al. 2014; Hulse, Reynolds et al. 2015; Hulse and Yates 2017).

These trends in Australia are consistent with international research, particularly in the years following the 2007-09 Global Financial Crisis (GFC). In the UK for instance, dependence on the private rental sector has grown as younger generations fail to achieve home ownership, while austerity measures have reduced new social housing supply (Kemp 2015; Byrne 2020). Similarly, in the US, falling rates of home ownership have been accompanied by an expanding private rental market; but this expansion has been primarily in the form of units targeting middle and higher income earners (Newman 2019). Despite a policy emphasis on increasing overall housing supply, these market solutions are not sufficient to alleviate housing stress for lower income earners (Been, Ellen et al. 2019).

The recent AHURI Inquiry on the future of the PRS (Hulse, Parkinson et al. 2018) reveals how the sector is changing in ways that will continue to place pressure at the low end, particularly among those with incomes in the bottom 20 per cent of income distribution, including the growing importance of intermediaries and digital technology in the sector.

Previous research has documented a growing shortage of private rental housing affordable and available for very low-income earners (Q1 households) nationally since 1996 (Hulse, Reynolds et al. 2014; Hulse, Reynolds et al. 2015). The situation is different when it comes to supply for low-income (Q2) households. Up until 2011, the total (aggregate) stock of PRS housing affordable to this group was in surplus ${ }^{3}$ although this disappeared when occupation by moderate to higher income households (and some very low-income households) was taken into account (Hulse, Reynolds et al. 2014; Hulse, Reynolds et al. 2015). In other words, moderate income earners who are shut out of home ownership then occupy lower rent housing, while very low-income earners unable to access an affordable unit are also competing for the same limited rental stock, generating supply shortages. The extent to which this process has continued was a key focus for this Inquiry.

3 That is, at a national level, there are more PRS dwellings affordable to Q2 households (supply) than there are Q2 households (demand). 
Changes to the nature of work and the increasing precarity of lower paid employment is also a recognised barrier to entering home ownership and/or accessing appropriate and affordable accommodation in the private rental market (Mullen, Marsden et al. 2020).

In response to these and wider concerns about housing affordability and supply, state governments have sought to reform perceived planning system barriers to medium and high density housing, particularly in areas well served by public transport. As noted, overall such reforms have enabled a supply response to high housing demand, but in general this new supply has not been affordable or available to lower income groups (Ong, Dalton et al. 2017). In some states, regulations on smaller scale rental accommodation (such as 'boarding' or 'rooming' houses) and accessory dwellings or 'granny flats' have also been relaxed (Gurran, Gilbert et al. 2018). The extent to which such initiatives have increased the supply of private rental housing affordable and available to lower income earners has not been the subject of specific research or evaluation to date.

\subsubsection{Job accessibility, commuting costs, and urban productivity}

The relationship between the location of housing and work is a key concept in understanding urban productivity. In theory, the housing market prices amenity and accessibility, with more accessible locations valued more highly by the market thus commanding a higher price or rent. Commuters may be in a position to 'trade off' accessibility to jobs for higher house prices and vice versa, but in practice Q2 households on low wages have limited options in the market and may need to move further from CBDs to obtain affordable housing. Some may move as far as satellite cities, seeking more affordable or better quality housing, or the opportunity to own, although the factors involved in moving to own and to rent may differ. As noted, satellite cities (such as Geelong in Victoria or Wollongong in NSW) have their own economic base/labour supply but they also provide commuting options for residents to work in the capital city (Melbourne and Sydney respectively).

However, long commuting distances may constitute a barrier to employment and cause wider economic stress (Mattioli, Lucas et al. 2016). This 'spatial mismatch' between the location of home and work (Kain 1968; Ihlanfeldt and Sjoquist 1998; Dodson 2005) may lead to some workers being excluded from participation in labour markets matched to their skills. Likewise, although it is sometimes assumed that long commutes are compensated by higher wages this may also generate high levels of commuter stress and reduced employment participation (Stutzer and Frey 2008; van Ommeren and Gutiérrez-i-Puigarnau 2011). This problem is likely to be most pronounced in residentially highly dispersed cities that exhibit a high degree of employment centralisation (van den Nouwelant, Crommelin et al. 2016; Li, Burke et al. 2017).

Households in more affordable fringe locations may consequently suffer from high commuting cost burdens (Dodson and Sipe 2008) or poor transit access (Welch 2013) unless they are able to find employment locally. Li, Dodson et al. (2017) showed that households with high commuting costs face strong inward relocation pressures to reduce travel burdens yet face converse housing affordability pressures. Recent studies show wider impacts of commuting on productivity, demonstrating links between distance to work and rates of absenteeism as well as employee performance (Ma and Ye 2019).

There is a distinct gender dimension to employment participation. Rates of underemployment (wanting to work more hours) are higher among women of all ages than for men ${ }^{4}$; and strategies to remain in the workplace despite long distances between home and work, are not equally available to women on whom the burden of caring responsibilities (e.g. school and childcare dropoffs/pickups and looking after elderly parents) tend to fall. However, the productivity impacts of lower levels of employment participation, or taking on lower skill work or part-time work to fit in with caring responsibilities (underutilised human capital), are difficult to measure.

4 The ABS measures rates of underemployment for men and women referring to those who are currently in the labour force but who want to work more hours (ABS Labour Force Australia, January 2020, cat no. 6202.0, Table 22). This series consistently shows higher rates of underemployment for women than men across all working age cohorts over 25 years. 
From a transport perspective, a city that experiences high commuting costs for a given level of economic output (or wages) is less productive than a city that has relatively low commuting costs (Weisbrod, Vary et al. 2003; Graham 2007; Lyons and Chatterjee 2008). The productivity of urban transport can thus be measured in terms of the costs of commuting relative to the value of economic activity that is generated via that travel, measured via wages. Similar travel time measures are typically used to measure the economic value of major transport infrastructure, for example Metz 2008.

The Australian Government, NSW Government and Victorian Government have recognised spatial job access problems via the ' 30 minute city' commuting performance indicators for major cities (Department of the Prime Minister and Cabinet 2017); however, improving performance against these indicators implies structural change in the spatial configuration of the urban system to increase lower cost homes near jobs, increase jobs near lower cost homes, and improve physical and digital connectivity between homes and jobs.

When designing these policy interventions, it is important to recognise the potential for perverse outcomes arising from the porosity of urban housing and employment markets. For instance, an increased supply of housing near central city jobs will not necessarily support lower income earners; similarly, jobs near locations of lower cost housing will not necessarily serve the residents of these areas. Further efforts are needed therefore to ensure that housing designed to meet the needs of lower income earners is allocated to priority groups; and to ensure that the benefits arising from new employment and economic opportunities are able to be shared with recipient communities.

Cities with relatively affordable housing close to their key employment nodes may have latent capacity to improve their urban productivity (Cervero 1989; Peng 1997). This effect could enable satellite cities to obtain a productivity advantage through affordable housing closer to their central employment sites, depending on the scale and composition of the employment offered and on transport links to the primate city. Of course, economic growth in these areas will also stimulate house prices and rents, however, Australia's satellite cities and regional localities tend to have fewer supply constraints than those in the major population and employment centres.

\subsubsection{Strategic spatial planning and funding interventions}

Internationally, metropolitan economic strategies or funding 'deals' between central and local governments around infrastructure investment, urban planning, or housing, have sought to address problems of spatially uneven housing and employment growth. Examples include the UK's City Deals (O'Brien and Pike 2015; Martin, Pike et al. 2016) which seek to deliver strategically integrated infrastructure (including housing) and economic development; France's Territorial Development Contracts (Gallez 2014) which set targets for housing construction and economic development proximate to new public transit; and Canada's Urban Development Agreements (Doberstein 2011) made across three levels of government to address issues including affordable housing and economic development. In a broader sense the US federal Community Development Block Grants (Rohe and Galster 2014; Galster 2017), which have sought to address housing and place-based disadvantage through local economic development since 1974, and Sustainable Communities Regional Planning Grants (Zapata and Bates 2017), which supported collaborative housing, economic and workforce development initiatives, provide examples of these strategic planning and funding interventions.

At the national level in Australia, the Smart Cities Plan (Department of the Prime Minister and Cabinet 2016) sets a policy framework for urban accessibility and innovation, while City Deals are developing a place-based funding, policy, and planning model across three levels of government. Earlier, the Building Better Cities program (1991-96) (Neilson 2008) supported a series of important demonstration projects which were instrumental in revitalising parts of inner Sydney and Perth in the 1990s. Critically, when urban investments catalyse new demand for housing because of increased accessibility to jobs, affordability will decline. Therefore, as recognised by the Building Better Cities program, investment in transport for urban infrastructure needs to be supported by strategies to produce and sustain affordable housing. 
This is an important consideration too in areas which will experience increased housing demand due to industry led developments, such as the emergence of technology and knowledge sector precincts-epitomised by Silicon Valley in California. Although Australia is yet to witness a tech hub of the likes of Silicon Valley, parallels can be draw in the high housing costs surrounding knowledge industry clusters of inner Sydney (e.g. surrounding Sydney, NSW, and Macquarie universities) and Melbourne (e.g. Monash, Melbourne universities).

\subsubsection{Smart city and innovation-led employment strategies}

Digital and innovation strategies are increasingly recognised for their potential to improve city productivity and provide new sources of employment growth (Katz and Wagner 2014). Further, international evidence suggests that localities offering relative housing affordability, particularly when connected to central markets by transport and Information and Communication Technology (ICT) infrastructure, are starting to perform well in attracting and fostering new economy jobs, for instance in health-tech, edu-tech, and auto-tech fields (Kurutz 2017; Moonen and Clark 2017). This suggests that the often under-utilised employment areas in Australia's de-industrialising middle and outer metropolitan and satellite cities might be productively reshaped to support new economy employment in creative, technical, and digital sectors.

Nevertheless, Australia's Smart Cities Plan anticipates the potential for smart technologies to better connect the location of homes and jobs, through the '30 minute city' (Department of the Prime Minister and Cabinet 2016). Significant investment in transport and infrastructure is needed to support this ambition. For regions such as Western Sydney in NSW, where there is an estimated deficit of around 200,000 jobs (Urbis 2013), more fundamental changes in the urban and housing system are necessary. Where lower paid Q2 workers (which may include early career innovation workers such as software developers and startup entrepreneurs) are unable to access affordable housing options near work, they and the firms that employ them may relocate to other labour markets or change their patterns of employment, reducing urban productivity.

A subset of studies have identified the inter-relationships between housing affordability and tech-led economic growth, primarily noting that affordability tends to decline when productivity increases, due to wage growth and associated gentrification policies (the 'Silicon Valley effect') (Glaeser, Ponzetto et al. 2014). However, recent work cataloguing the rise of startups across US metropolitan areas suggests that older industrial cities such as Cleveland may be harnessing the opportunities associated with lower land and housing values which enable knowledge entrepreneurs to incubate with lower upfront costs (Morelix, Fairlie et al. 2017). Others emphasise the importance of place-based policies which support clusters of local entrepreneurs within environments known to attract and sustain creative and knowledge workers, such as cultural amenities and social diversity (Florida 2002).

Overall, place-based interventions targeted at the needs of lower income employees and matched to particular market conditions are needed to manage the housing market impacts associated with a 'tech-boom' effect (Quercia, Stegman et al. 2002; Nelson 2002). These interventions include rental subsidies as well as requirements for new affordable housing in job rich locations (Palm and Niemeier 2017).

\subsubsection{Summary and preliminary implications for policy development}

There is growing concern about uneven economic growth in metropolitan and regional Australia, and relationships between housing, labour markets, and urban productivity (Department of Infrastructure and Regional Development (DIRD) 2015). However, strategies to address spatial mismatch between employment opportunities (clustering in central city locations) and affordable housing supply (gravitating to outer suburban and regional Australia) remain undeveloped. For example, a 2011 review of capital city planning frameworks found evidence of strategic policy support for new infrastructure, investment, and innovation, but poor integration across priorities and inadequate strategies for addressing housing affordability (COAG Reform Council 2011). This problem has been compounded by the loss of traditional sources of employment in middle and outer metropolitan suburbs and in regional or satellite cities such as Geelong and Wollongong, with the decline of manufacturing sectors including automotive and related industries (Department of Infrastructure and Regional Development (DIRD) 2015; Beer 2018). 
For workers in Q2 households in particular, and the firms that seek to employ them, it is critical that strategic planning frameworks and transport or infrastructure investment in metropolitan and regional cities combine to support and increase the supply of affordable rental homes, since this provides greatest flexibility in the housing system. However, evidence to date shows that existing strategies are not sufficient. Strategies have primarily sought to increase housing supply in accessible locations through higher density infill and renewal projects and road upgrades, with some public transport investment to reduce commuting times from middle and outer suburban locations.

Recent AHURI research demonstrated that these approaches seem to have influenced the quantum and location of new housing supply-new, particularly higher density, housing is gravitating towards job rich and accessible localities (Ong, Dalton et al. 2017). However, this new supply is not necessarily suitable for those experiencing work participation barriers associated with transport accessibility, such as women with caring responsibilities. Nor is it directly affordable to lower income workers, or 'freeing up' other lower priced homes through a 'filtering' process (ibid). Rather, because proximity to jobs and transport infrastructure remains uneven in metropolitan housing markets, new housing is failing to dampen housing prices or rents in accessible localities. This implies that, without policy intervention, affordable housing supply will continue to gravitate away from, rather than towards, employment opportunities.

Internationally, strategic policy interventions and funding deals have been used to address spatially uneven employment and housing growth. These approaches have in common the idea that 'bespoke', place-based interventions are needed to address and respond to complex contextual factors, meaning that a diversity of models have emerged internationally with different funding, governance, and implementation arrangements. There are potential lessons for Australia in this experience, as the City Deal model becomes an increasingly important lever for strategic place-based funding.

Further, despite the potential for digital innovation and technology industries to support economic growth in suburban and regional areas, intersections between smart city initiatives and affordable housing supply strategies remain undeveloped.

\subsection{Research methods}

The Inquiry Program sought to address these themes through four separate but intersecting projects, using both quantitative and qualitative research methods. A quantitative evidence base was developed to examine the changing location and availability of affordable private rental housing in metropolitan capital and satellite cities, alongside household employment characteristics, commuting costs and labour market participation. From this quantitative evidence base, qualitative research examined international and Australian strategic policy and funding interventions to unlock employment and housing opportunities and examined, in particular, issues and opportunities surrounding the digital and innovation sector.

\subsubsection{Case study selection}

Across the Inquiry, Sydney, Melbourne, Wollongong and Geelong were a particular focus for analysis. These metropolitan and satellite cities were selected because of the economic significance of Sydney and Melbourne and the ongoing barriers to affordable rental housing provision in accessible locations within these regions (National Housing Supply Council 2014, Department of Infrastructure and Regional Development (DIRD) 2015). The inclusion of the satellite cities of Wollongong and Geelong allowed us to investigate the potential role these cities can play in offering more affordable housing choices for Q2 workers and in diversifying local employment opportunities beyond the central city ring. 


\subsubsection{Examining changes in the supply of affordable rental housing in Australian cities, 2011-16}

The research method for examining changes in the supply of affordable rental housing (Inquiry Project A, Hulse, Reynolds et al. 2019 ) involved original empirical analysis using customised data from the most recent Census of Population and Housing conducted by the ABS in August 2016. The data were carefully specified by the research team and discussed in detail with ABS personnel. The methodology substantially replicates, and enhances the approach used in four prior AHURI projects (see Hulse, Reynolds et al. 2019 for a full description). It is based on an approach first employed in the 1990s by the US Department of Housing and Urban Development (Nelson 1994), further developed in the 2000s (Vandenbroucke 2007) and adapted for use in Australia by Wulff and Yates (2001).

As a key part of this project was to update analysis in the previous studies, great care was taken to ensure validity and reliability through consistent definitions, measures and spatial units. The methodology first assumes that housing can be assigned to households on the basis of affordability in order to identify the shortages or surpluses of rental units affordable to households with incomes in the first two quintiles of the national gross household income distribution. It then recognises that not all affordable units are available because of prior occupation by renters with higher incomes.

To analyse shortages/surpluses of affordable private rental dwellings in 2016 and over time, PRS households were grouped into gross household income quintiles (based on the national distribution). Since previous research (Wulff, Reynolds et al. 2011; Hulse, Reynolds et al. 2014) showed that households in the lowest quintile (Q1, bottom 20\%) face different PRS affordability problems than those in the second lowest quintile $\left(Q 2,21-40 \%{ }^{5}\right)$, the shortage analysis was again undertaken separately for each lower income group. To determine whether households in each quintile were paying affordable rent, private rent categories corresponding to 30 per cent of the upper value of the household income quintile were created. The affordable rental range for the key Q2 household group was rents up to \$355 per week (\$2016).

This approach provided the basis for the analyses of Census data 1996-2016 on affordable and available rental housing supply for Q1 and Q2 private renter households, across 88 spatial units (national, state, metropolitan, non-metropolitan; 55 labour market areas within major capital cities, and 22 regional towns with a sufficiently large private rental market).

\subsubsection{Examining affordable rental housing, spatial employment structures, commuting cost burdens and urban productivity}

Inquiry Project B examined how affordable housing, urban employment structures and commuting costs influence labour market participation, jobs-skill matching and urban productivity, focusing on two major cities, Sydney and Melbourne, and their satellites Wollongong and Geelong (Dodson, Li et al. 2020). Extending the household level analysis (Inquiry Project A) of spatial employment patterns, this included a commuting perspective in relation to the distribution of affordable housing supply, and focused on individual low-income workers rather than households, since individuals within low-income households are likely to have different commuting patterns.

The research involved advanced spatial modelling of housing and labour markets within these areas, drawing on specially prepared ABS Census datasets, and testing of alternative spatial affordable housing and employment scenarios to assess optimal distributions of housing and employment for urban productivity.

Modelling of commuting costs was informed by previous research on housing and transport spatial cost structures (Dodson 2004; Dodson and Sipe 2007; Dodson and Sipe 2008; Li, Dodson et al. 2015; Li, Burke et al. 2017). A comprehensive spatial model was developed to appraise commuting patterns, transport costs, and productivity of workers for a range of industries and occupations in Melbourne, Sydney, Wollongong and Geelong. This model provided the basis for investigating the effect of affordable housing supply and spatial labour market dynamics on household commuting costs and, by extension, urban productivity in these cities.

5 In this Census-based study, the annual income of Q1 households was up to approximately $\$ 35,000$ (\$2016) and for Q2 households, it was between $\$ 35,000$ and $\$ 61,500$ per annum. 


\subsubsection{Investigating existing and potential strategic planning and funding interventions for making affordable rental housing more accessible to employment opportunities}

The third Inquiry Project (C) examined Australian and international evidence on the range of strategic planning and funding interventions for lifting economic growth and urban productivity, focusing on access to affordable rental housing (Pill, Gurran et al. 2020). The qualitative study involved:

- An international evidence review of strategic place-based funding approaches or deals and practice in the UK, Europe and North America. The review was supplemented by interviews with five UK academic and practitioner experts given the Australian policy focus on the UK City Deals approach.

- Second, using the overarching national policy umbrella of the Smart Cities Plan (Department of the Prime Minister and Cabinet 2016) and '30 minute city' as a frame, a review was conducted of Australian capital city strategic planning frameworks focusing on spatial relationships between employment/jobs growth and housing supply strategies.

- The above review informed the more detailed review of strategic planning and funding interventions in the four case study areas: Sydney (with a focus on Western Sydney City Deal) and the satellite city of Wollongong; and Melbourne, and the satellite city of Geelong (now subject to the Geelong City Deal). This entailed an analysis of existing and potential strategic planning and funding interventions relevant to balanced housing and employment growth, informed by interviews.

Semi-structured interviews (face-to-face and by telephone) were conducted with 20 key city planning, infrastructure, and economic development informants with state and/or specific capital and regional city planning experience and expertise. These included interviews with officers in four of the eight constituent local government areas of the Western Sydney City Deal; and three officers of the City of Greater Geelong (Geelong City Deal) conducted between December 2018 and April 2019. A further five semi-structured interviews with key UK academic and practitioner experts informed the development of shared themes and critiques, while identifying scope for improvement and lessons for Australia.

\subsubsection{Examining smart cities, innovation economies, and affordable rental housing}

Inquiry project $\mathrm{D}$ investigated the relationships between affordable rental housing in supporting digital innovation and employment growth in metropolitan and satellite cities (Dowling, Maalsen et al. 2020). Through an international evidence review, case studies, and interviews with urban planners and representatives from knowledge industry firms, it identified 'smart city' exemplars - models for leveraging information and communications technology and infrastructure to support new economy jobs near affordable rental supply. Specifically, the project:

- Reviewed the international evidence on the role of affordable rental housing in supporting digital innovation and employment growth in metropolitan, suburban, and satellite city areas;

- Examined the labour market constraints and location decisions of digital and startup firms and the role of affordable rental housing options in supporting access to a deep labour pool, in selected Australian metropolitan and satellite cities; and

- Developed potential models of digital and innovation-led employment drawing on cases and emerging examples within new urban and residential development projects as well as within renewing suburban and regional settings.

In particular, the project examined the barriers and opportunities around particular locations for knowledge economy firms, including the relative trade-offs made between the benefits of clustering and agglomeration in strategic central city locations, versus labour market access, transport costs, and housing choice. A specific focus for the interviews was whether knowledge economy firms perceived locational advantages or disadvantages in areas where affordable rental housing is more available, such as parts of outer Melbourne and Western Sydney and in the satellite cities of Wollongong and Geelong. 
A total of 29 semi-structured interviews were held with local and state government strategic planners, local economic development officers, senior state government bureaucrats, and a variety of small businesses and umbrella organisations from across the four case study areas: Sydney and Wollongong (NSW), Melbourne and Geelong, Victoria.

\subsection{Summary of Inquiry research approach, data sources, and the structure of this report}

The specific research questions, methods, and data sources for each of the supporting research projects are summarised in Table 1.

Table 1: Summary of Inquiry research project questions, methods, and data sources

\begin{tabular}{|c|c|}
\hline Research questions & Methods and data sources \\
\hline $\begin{array}{l}\text { How has the supply of affordable and available private rental } \\
\text { housing changed from } 2011-2016 \text { nationally and at a variety } \\
\text { of spatial scales, and what is the performance of capital cities } \\
\text { and satellite cities in providing affordable and available supply } \\
\text { for Q2 households in ways that could enhance productivity? }\end{array}$ & $\begin{array}{l}\text { Quantitative research on the private rental market to extend } \\
\text { analysis of affordable private rental housing supply across } \\
\text { Australian metropolitan and non-metropolitan regions from } \\
\text { 1996-2011 to incorporate } 2016 \text { Census data (Project A). }\end{array}$ \\
\hline $\begin{array}{l}\text { How can strategic spatial planning and funding interventions } \\
\text { leverage affordable rental housing choices near employment, } \\
\text { enhancing urban productivity? }\end{array}$ & $\begin{array}{l}\text { National and international examination of strategic planning } \\
\text { and funding interventions and 'City Deals', identifying levers } \\
\text { for increasing affordable rental housing delivery and economic } \\
\text { growth in metropolitan and satellite cities (Project C). }\end{array}$ \\
\hline
\end{tabular}

Source: Authors.

There are inevitable limitations in relation to the research conducted for this Inquiry. The Inquiry focus on Q2 low-income households provides a helpful lens for understanding the housing needs and constraints of a critical sector of the population and workforce, but wider intersections between this cohort and the supply and demand of housing affordable to Q1 and Q3 housing are not explored in depth. We were not able to focus on wider demand side factors influencing the housing market (such as interest rate movements) more generally and the implications for access to first home ownership; or the potential impact of wage or income increases on home purchase or rental affordability. This is particularly important since dwellings typically move between home ownership and rental in Australia. The research focus on Australia, and specific jurisdictions in Australia, may limit wider international transferability of our findings.

Finally, the research conducted for this Inquiry was undertaken prior to the COVID-19 Pandemic. While many of the findings remain relevant in the current and anticipated future period, further research on the changing relationships between housing affordability and urban productivity will remain a priority in the post-COVID era.

The following sections of this report synthesise the key findings emerging from each of the Inquiry projects. Chapters 2 and 3 focus on the changing supply of affordable and available private rental housing, relative to locations of employment, commuting patterns of lower income workers and the job accessibility of existing and potential affordable rental housing. Chapter 4 turns to the range of existing and potential policy interventions used internationally and in Australia, as well as the potential for satellite cities and decentralised employment growth-potentially through digital innovation - to increase housing and employment opportunities for lower income workers. Lastly, Chapter 5 summarises and highlights priorities and options for further policy development. 


\section{The changing supply of affordable and available private rental housing}

- This chapter examines changes in the supply of private rental housing which is affordable and available for lower income households, across Australia's cities and regions, with a particular focus on Q2 households.

- It highlights long term growth and change in the private rental sector (PRS), which is the fastest growing part of the Australian housing system, increasing by 17 per cent in 2011-2016, more than twice the rate of household growth (7\%).

- Nevertheless, there is a national shortage of 173,000 dwellings in the private sector affordable and available for Q2 households, with the most extreme shortage in Sydney.

- Further, the geography of PRS supply affordable and available to Q2 households is gravitating away from central city employment opportunities, with affordable private rental stock increasingly located in outer suburbs of capital cities and in satellite cities.

- Whether there is a 'spatial mismatch' between employment opportunities and affordable rental housing depends substantially on i) the concentration/ dispersion of different type of jobs relative to the employment profile of Q2 households; and ii) the extent to which these households trade off rental affordability for access to employment opportunities in inner/middle suburbs or trade off access to jobs for lower rents in outer suburban locations. 
The private rental sector is an increasingly important part of the Australian housing system, as access to home ownership is constrained by higher house prices, particularly in urban areas. The importance of the PRS has been reinforced by declining access to a shrinking social rental sector that was already small compared to some other advanced economies. More than two million households rented their housing in 2016 or almost a quarter of all Australian households ${ }^{6}$, with a two percentage point increase in the five years from 2011-16. This increase in private renter households accounted for more than half (55\%) of all household growth, with the increase in private renter households $(288,816)$ greater than the increase in all home owner households $(223,316)$ during this five year period. This is the first time that this has occurred since detailed analysis of changes in intercensal periods began with 1996 as the base year.

Within this context, this chapter briefly summarises the international literature on private rental supply before reporting on some key findings of detailed research into affordable housing supply in urban Australia. The chapter draws extensively on the detailed analysis in the published report The supply of affordable private rental housing in Australian cities: short- and longer-term changes (Hulse, Reynolds et al. 2019).

\subsection{Existing research on affordable private rental supply}

Growth in the PRS is occurring not just in Australia but also in a range of other advanced economies, particularly in the Anglophone world ${ }^{7}$ (e.g. Byrne 2020; Carliner and Marya 2016; Crook and Kemp 2014; Hulse and Yates 2017; Martin, Hulse et al. 2018; Whitehead, Monk et al. 2012). PRS growth has increased most notably since the Global Financial Crisis (GFC) of 2007-09 (Forrest and Hirayama 2015; Kemp 2015; Martin, Hulse et al. 2018).

In the research reviewed for the project (Hulse, Reynolds et al 2019: 11-12), a number of key trends in PRS supply were identified:

- Growth in PRS supply is associated with an increase in small scale investor-landlords attracted by prospects of capital gain in an era of escalating house prices and seeking a safer investment to help provide for their retirement and to assist their children (Crook and Kemp 2014; Ronald, Lennartz et al. 2017; Martin, Hulse et al. 2018; Ronald and Kadi 2018).This has also been the case in Australia (Hulse, Reynolds et al. 2019).

- An increase in larger-scale institutional investment in apartment complexes in countries such as the US and the UK has been based on a 'develop and hold' model ${ }^{8}$ rather than a 'develop and sell' one (Martin, Hulse et al. 2018). This model includes both new and repurposed buildings for rental (Fields and Uffer 2016). In the US, large corporate landlords also have portfolios of single family properties acquired after the GFC (Beswick, Alexandri et al. 2016; Fields 2018). The challenges in getting institutional investment into affordable rental housing in Australia and some of the possible vehicles for doing this have been well documented (Milligan, Yates et al. 2013; Lawson, Pawson et al. 2018).

- A surge in lending for investment in PRS properties has been observed in the context of historically low interest rates after the GFC, enabled by specific financial products such as buy to let mortgages in the UK and interest only loans in Australia (Kemp 2015; Martin, Hulse et al. 2018).

- While regulation of the PRS is often under the spotlight as a potential inhibitor of investment in PRS supply, comparative research finds that there is no direct relationship between regulation of the PRS, and the size and composition of the sector (Whitehead, Monk et al. 2012) and that regulation of residential tenancies by the Australian states/territories is relatively weak compared to other countries, particularly those in Europe (Hulse, Milligan et al. 2011; Martin, Hulse et al. 2018).

6 In this series of reports, 'private renter households' exclude those households paying $\$ 0$ rent - around 36,600 households in 2016. As a result, the proportion of all Australian households renting privately is slightly lower than might be reported elsewhere.

7 Generally considered to be Australia, New Zealand, the UK, Ireland, Canada and the US.

8 Called multi-family housing in the US and build to rent in the UK. 
Taken together, these trends suggest that the PRS in the Anglophone countries is growing but also changing. The sector has become increasingly financialised with investor landlords taking on debt to finance their properties and a greater number and range of households is involved as landlords and as tenants. A key concern internationally is the effect of types of financing, supply trends and the extent and type of regulation on outcomes for lower income and vulnerable private renter households (Bone 2014; Byrne 2020; Dewilde 2018; Kemp 2015).

While a good deal of research into the PRS has been driven by social justice issues associated with accommodating those on very low (Q1) household incomes (Productivity Commission 2019), growth and change in the PRS also raises issues about labour force participation. The PRS is important in that it provides greater flexibility than home ownership (or social rental), easier entry and exit and lower transaction costs, facilitating households to relocate to live in reasonable proximity to jobs, enabling additional hours to be worked and arguably contributing to greater productivity (OECD 2011).

It is also relevant to note that barriers to home ownership amongst higher income earners means that more of the workforce is dependent on the PRS, exacerbating competition for affordable rental housing.

\subsection{Structural changes in the Australian private rental sector}

\subsubsection{National level changes in the Australian PRS}

The Australian PRS has been growing since the mid-1990s and now has a critical role in the Australian housing system. The number of private renter households grew by 17 per cent in the five years 2011-16, more than twice the rate of growth of all households (7\%), continuing a trend observed since 2001 . This growth has offset a decline in home ownership and some decline in social housing sector, as shown in Figure 2.

Figure 2: Per cent change in the number of households by housing tenure, 2011-16 and 2006-16, Australia

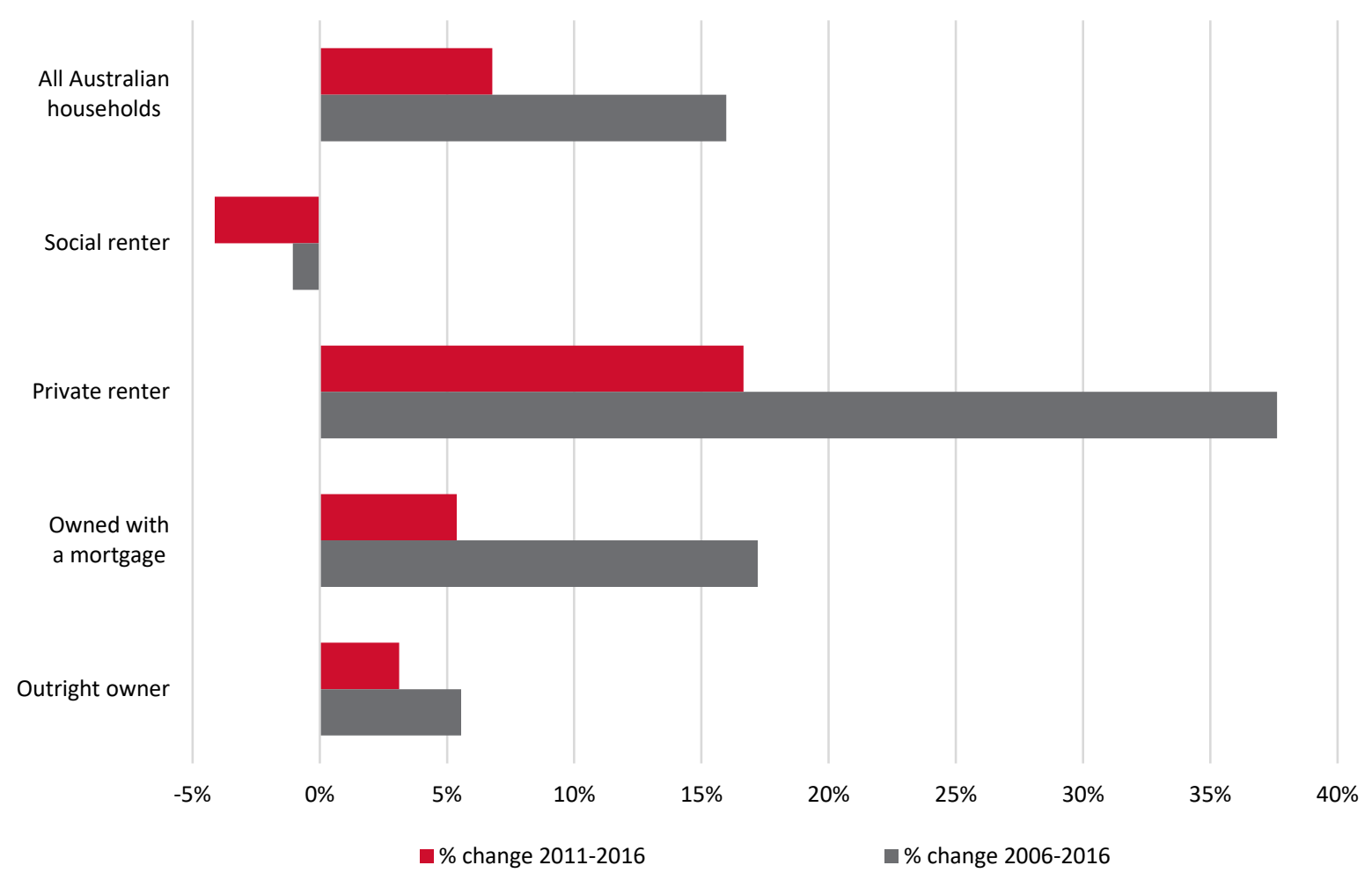

Source: ABS customised matrices derived from the Australian Census of Population and Housing 2006, 2011 and 2016. 
Research for the Inquiry also detailed the extent of structural change in the sector.

- Rents which in 1996 had been clustered at levels affordable to lower income households, moved to mid-market levels that are affordable to middle and higher income households.

- While there has been some increase in the number of lower income households due to sector growth, there has been a particular increase in private renter households with middle and higher incomes.

The result of these changes has been increasing shortages of rentals affordable to lower income households. Project A for the Inquiry examined in detail the increased shortages facing households on very low incomes (Q1) from 2011-16, nationally, in large cities and in a range of regional cities and towns. It found increasing shortages of affordable rental supply, raising an important social justice issue for social policy makers and practitioners. How can Australians on very low incomes (including many on pensions and benefits) living in metropolitan (and some non-metropolitan regions) access housing that enables them to live decent lives without undue financial stress? Readers can find full details of changes in affordable private rental supply in the Project A report (Hulse, Reynolds et al. 2019). However, Q1 private renters are predominantly not in the labour force (56\%) or have one part-time earner (19\%) (Hulse, Reynolds et al 2019: Table 13). Prospects for moving into the labour force are often limited by age, disability, caring responsibilities and other factors.

In this report, we are primarily concerned with the linkages between affordable rental housing supply and economic productivity, and consequently focus on Q2 private renter households, most of whom are in the labour market. The restructuring of the private rental sector is likely to have adverse effects on the labour force participation of Q2 private renter households living in major capital cities, particularly Sydney and Melbourne, if they are not able to find affordable rentals close to jobs, negating the assumed flexibility of the private rental sector.

\subsubsection{Increasing shortages of affordable and available private rental housing for low- income (Q2) households in urban Australia}

In theory, there is a significant surplus of rental housing nationwide that is affordable to Q2 households. The problem facing Q2 households nationally is not supply, as for Q1 households, but availability - primarily because many of the rentals that are affordable to Q2 households are occupied by households on middle to higher incomes (Q3-Q5), a demographic that, as discussed, has been increasing in the PRS. The notionally large national surplus of 491,000 PRS dwellings for Q2 households in 2016 became a shortage of 173,000 affordable and available PRS dwellings nationwide when availability is included (up from 122,000 in 2011) (Hulse, Reynolds et al. 2019: 36).

This shortage was more acute in metropolitan ${ }^{9}$ regions than non-metropolitan ones in 2016, although in both cases, higher percentages of Q2 households paid unaffordable rents in 2016 than in 2006 or 2011 (Hulse, Reynolds et al. 2019: Table 4, 36). In metropolitan regions, the percentage of Q2 households paying unaffordable rents increased from 29 per cent to 46 per cent between 2006 and $2016^{10}$.

9 Metropolitan regions are the combination of Australia's state and territory capital city areas (and includes all the Australian Capital Territory). Non-metropolitan regions are the balance of areas outside of this.

10 In non-metropolitan regions, the equivalent figures were 17 per cent (2006) and 20 per cent (2016). 
Figure 3: Shortage of affordable and available rentals for Q2 PRS households in metropolitan regions, 2006, 2011, 2016

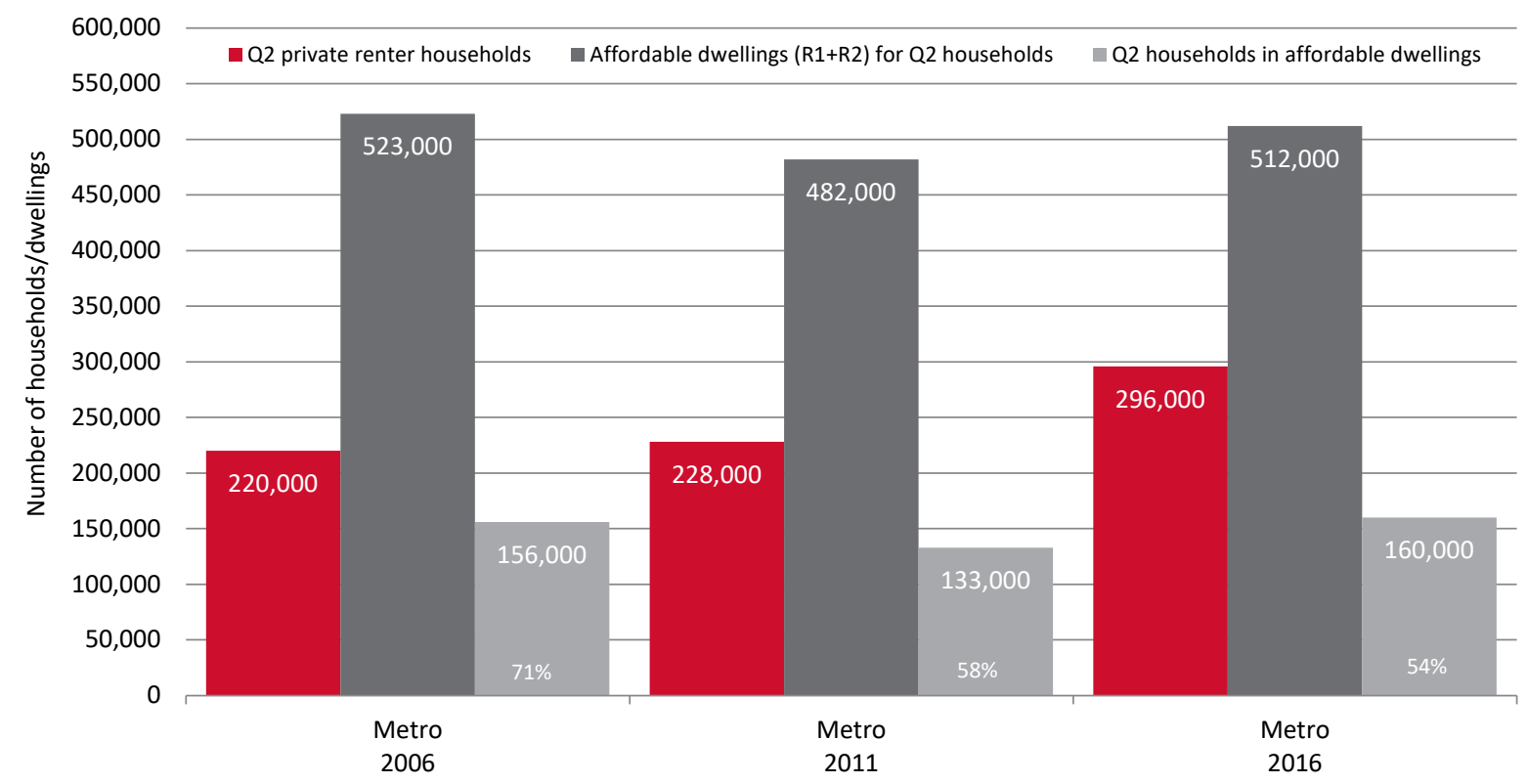

Source: Adapted from Hulse, Reynolds et al, 2019: 36, Table 4, drawing on customised matrices derived from the Australian Census of Population and Housing 2006, 2011 and 2016.

These are national figures which give a broad overview of restructuring of the private rental sector, notably 2006-16. In the next section, we explore the urban geography of changes in affordable and available private rental supply for Q2 households, focusing on capital cities, particularly the two biggest cities of Sydney and Melbourne and their satellite cities.

\subsection{Affordable and available private rental supply for Q2 households in capital and satellite cities}

\subsubsection{Capital cities}

Q2 private renters face a deteriorating situation in terms of affordable and available private rental supply across Australia's capital cities. In particular:

- There was an absolute shortage of affordable housing for Q2 households of 5,900 dwellings in Sydney in 2016 compared to a surplus of 35,800 dwellings affordable for these households in 2011. Theoretical surpluses of affordable rental supply for Q2 households remained in 2016 in all other capital cities, although in most cases this had decreased compared to 2011 and 2006. (Hulse, Reynolds et al. 2019: 43, Table 6)

- When occupation of the stock which is affordable to Q2 households by higher income Q3-Q5 households (and some very low-income Q1 households) is considered, in all capital cities surpluses became shortages and those shortages increased in 2011-16 with the exception of Darwin. Sydney has the greatest shortage of affordable and available housing at 60,000 dwellings, up from 40,500 in 2011. Melbourne, Brisbane and Perth also had significant shortages in 2016 which were greater than in 2011 (Hulse, Reynolds et al. 2019: 43, Table 6).

- Affordability outcomes generally deteriorated as a result of increased shortages. Most worryingly, 71 per cent of all Q2 private renter households in Sydney paid unaffordable rents in 2016 (up from 55\% in 2011) ${ }^{11}$. This contrasts with Melbourne where the proportion of Q2 renters living in unaffordable housing was on the national average in 2016 (36\%) (Hulse, Reynolds et al 2019: 43, Table 6).

11 After Sydney, Darwin and Canberra had the highest percentages of Q2 households paying unaffordable rents in 2016. 


\subsubsection{Regions within capital cities}

If we look in more detail at affordable supply for Q2 households in the two largest capital cities, without for the moment considering availability (occupancy by higher income households), we find that Sydney and Melbourne show different trends in 2006-16 (Figure 4).

- The affordable rental stock for Q2 households decreased markedly in Sydney and across inner, middle and outer regions;

- The affordable rental stock for Q2 households in Melbourne increased somewhat during this decade, particularly in outer regions of the city.

Figure 4: Changes in the supply of housing affordable to Q2 PRS households in inner, middle and outer regions of Melbourne and Sydney, 2006, 2016

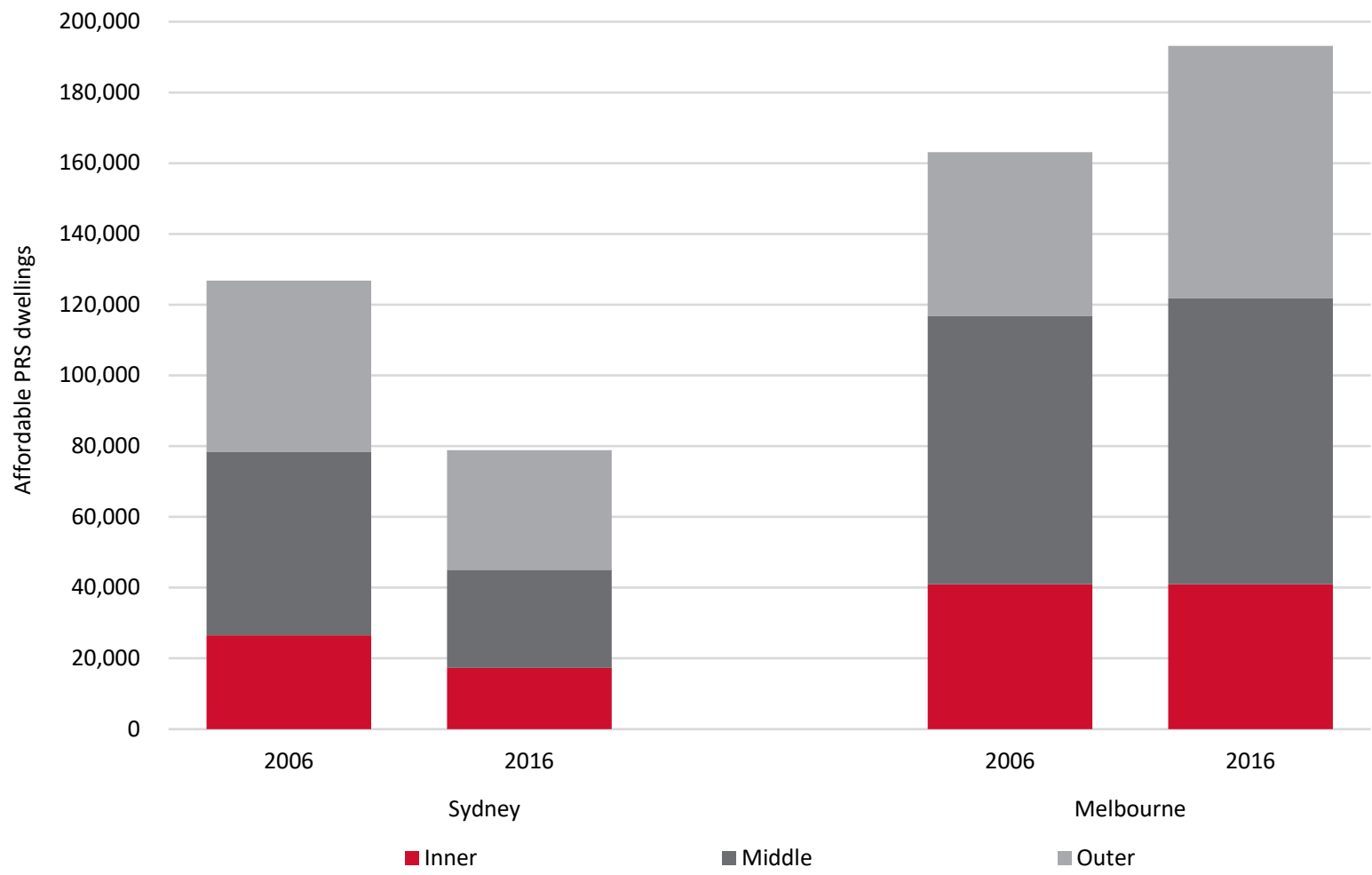

Source: Hulse, Reynolds et al 2019: 45, Figure 11.

When we factor in availability (occupation of this stock by middle to higher income households), the shortages become more significant across all regions of Sydney and in the inner and middle suburbs (Hulse, Reynolds et al. 2019: 44-48). As a result, 80 per cent of Q2 households were paying unaffordable rents in inner Sydney in 2016 and 76 per cent in middle Sydney. In Melbourne the figures were 53 and 35 per cent respectively (Hulse, Reynolds et al. 2019: 59, Table 11).

Figure 5 shows the increased shortages of affordable and available dwellings for Q2 private renter households in inner, middle and outer regions of Sydney and the selected satellite cities for this Inquiry (Wollongong and Geelong). It also includes figures for Newcastle (NSW) which although further from Sydney may experience some spillover from the Sydney housing and employment markets. 
Figure 5: Shortage of affordable and available dwellings for Q2 private renter households, Sydney and Melbourne (inner, middle, outer) and selected satellite cities, 2006, 2011, 2016

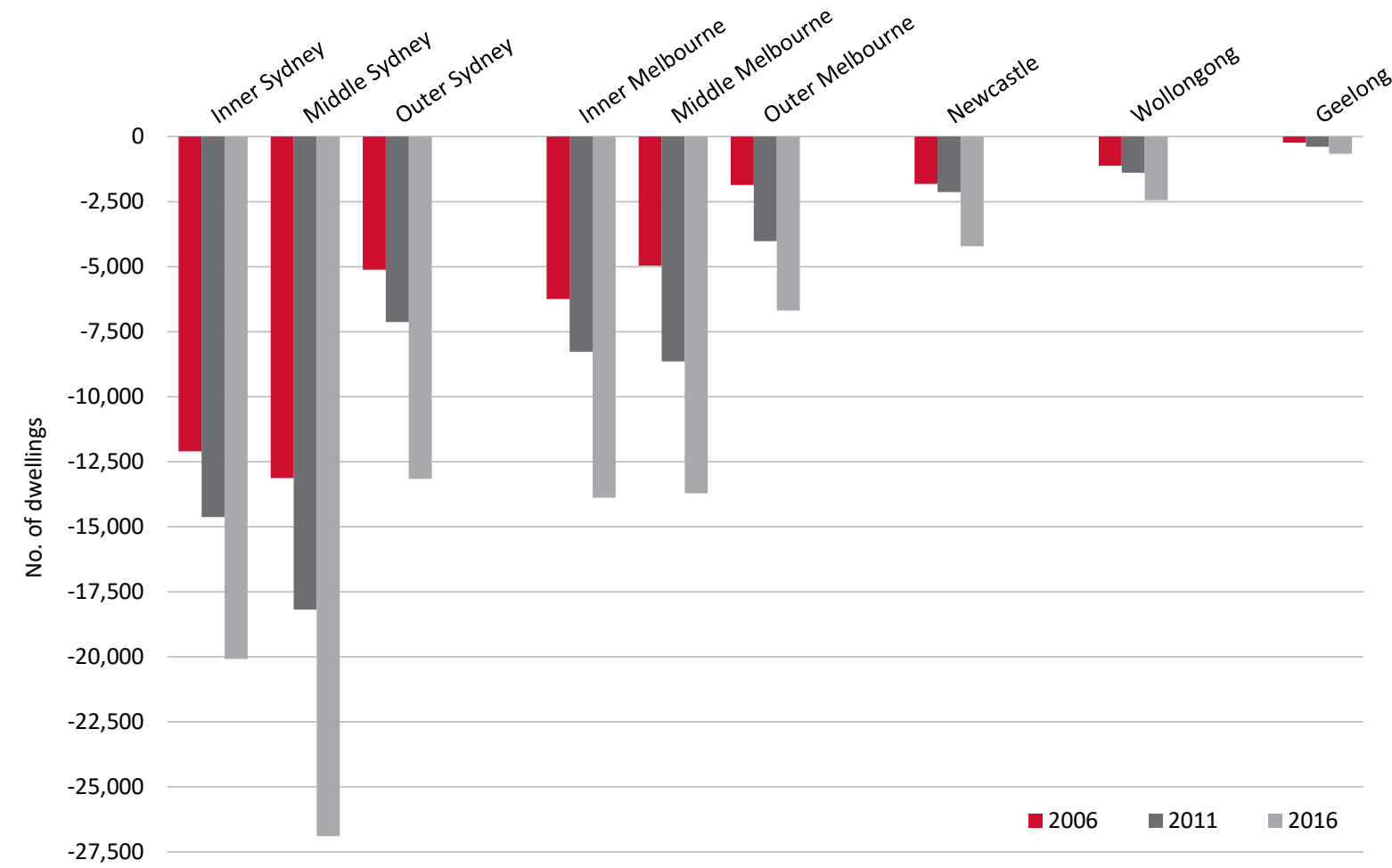

Source: Adapted from Hulse, Reynolds et al 2019: 47, Figure 13: 49, Figure 15, calculated from ABS customised matrices derived from the Australian Census of Population and Housing 2006, 2011 and 2016.

The situation facing Q2 households in some satellite cities also deteriorated in 2011-16 and 2006-16.

In terms of the satellite cities which are the particular focus on the Inquiry ${ }^{12}$ (Wollongong, Geelong and Newcastle):

- In Wollongong and Newcastle (NSW), there were shortages of affordable and available supply for Q2 households in 2016 of 2,500 and 4,200 dwellings respectively. In Geelong (VIC) the equivalent shortage was 700 rental dwellings (Hulse, Reynolds et al 2019: 110, Table A9).

- In Wollongong 46 per cent of Q2 renter households were paying unaffordable rents and in Newcastle 35 per cent. The equivalent figure in Geelong was 13 per cent, indicating a much less pressured rental market. (Hulse, Reynolds et al 2019: 110, Table A9).

For Q2 households, the shortage in Newcastle and Wollongong deteriorated most in 2011-16, perhaps reflecting a spillover of the extreme shortages in the Sydney market during this period discussed above. In Victoria, it appears that there is an increasing supply of affordable housing in the outer suburbs of Melbourne for Q2 private renter households, as discussed previously in this chapter, so the spillover to Geelong in terms of private rental appears minimal (although noting that this may not be the case for home purchase).

12 It should be noted that the largest shortage of affordable and available supply for Q2 households in satellite cities was in the Gold Coast (Queensland) and there were also significant shortages in Sunshine Coast (Queensland) (Hulse, Reynolds et al 2019: 50, Figure 16). 


\subsection{Summary and implications for policy development}

The Australian private rental sector has grown by at least twice the rate of all household growth over the decade 2006-16. In theory growth of the PRS provides greater flexibility for members of Q2 (and other) households to locate in proximity to suitable jobs, in contrast to those who are home owners or social renters, for whom moving is more difficult and/or more expensive. Improving the aggregate supply of PRS housing should support employment participation and contribute to greater economic productivity.

There has, however, been considerable restructuring of the private rental sector in urban Australia, particularly since 2006. Increases in rental supply have been predominantly at levels affordable to moderate and higher income households, although there remains a notional surplus of affordable supply for Q2 households nationally and in most cities, with the notable exception of Sydney in 2016. However, the PRS is now housing more middle to higher income households than in 2006 (or 1996), which has the effect of increasing competition from Q3-Q5 households for rentals affordable to Q2 households. This has predictably occurred in areas where there is a good supply of jobs - near city centres and in inner and middle suburbs - and productivity is highest. This has led to increased shortages of affordable and available housing for Q2 households in these locations and, in Sydney, also in the outer suburbs. Increasing shortages of supply of affordable rental housing for Q2 households in Wollongong (and Newcastle) may indicate some spillover from the higher rent Sydney market, although this appears not to have been the case for Geelong.

The implications for policy are threefold:

- Firstly, and as discussed further in the following chapters, strategies are needed to increase affordable supply for Q2 households so that they can rent, or continue to rent, in inner and middle suburbs with good access to jobs. Such strategies will make more effective and intensive use of land, including greater density development within existing planning schemes, and targeting rezoning of some areas to achieve greater densities in areas which are jobs-rich and/or well served by public transport. In considering such urban consolidation strategies, it is important to focus not only on affordable supply for Q2 households in the short term but also to develop ways to maintain affordable supply for these households in the medium and longer term.

- Secondly, complementary strategies to diversify employment in outer suburbs and regional centres where there is a good supply of rental housing affordable to Q2 households are needed. As outlined in Chapter 3, jobs in these areas are often lower paid and require lower skills. The lower land values, however, also provide a golden opportunity to generate new types of jobs in technology and other innovative parts of the economy. Planning affordable (rental) housing as a key component of economic development and business innovation would enable improved and more diverse employment opportunities.

- Thirdly, the findings show that cities differ in the extent of rental housing restructuring and the accessibility of employment due to transport and other infrastructure. It is important that customised approaches, rather than 'one size fits all', are developed to plan housing, employment and transport that meet local requirements. A key principle is to focus on creating desirable places to live with desired infrastructure, amenities and services, whether in capital or satellite cities, learning from some overseas examples, as we shall see in Chapter 4. 


\section{Housing stress, commute burdens, and employment access}

- This chapter looks at the commuting burden of Q2 renters and examines workforce participation of Q2 renter households relative to where they live, drawing together findings from two of the research projects which supported this Inquiry.

- It highlights research evidence that lower income households in the major employment centres of Sydney and Melbourne appear to be trading off affordable rental housing for access to jobs. On average, low-income workers pay 8.6 per cent and 9.4 per cent of their gross income on commuting costs, in Sydney and Melbourne respectively.

- However, many lower and moderately paid jobs and part-time jobs are dispersed throughout the metropolitan areas, accessible to low and moderate income households in capital and satellite cities.

- Satellite cities of Wollongong and Geelong offer access to more affordable rental housing, and increasing jobs growth and diversification in these areas may ease congestion pressures in Sydney and Melbourne, and support more housing and employment choice for workers, including lower income earners. 
Previous chapters established that there has been a long term decline in the supply of affordable and available private rental housing in Australian cities and regions. This chapter considers the implications for urban productivity of these findings in more detail, focusing on Sydney and Melbourne as case study cities. Together these cities housed more than 10 million people and generated more than 75 per cent of the nation's GDP growth in 2018-19 (SGS 2019). The analysis expands to consider the existing and potential roles of satellite cities Wollongong and Geelong with their strong ties to Sydney and Melbourne respectively.

The chapter first examines the broad geography of employment in Greater Sydney and Melbourne, in relation to the location of rental housing affordable to lower income workers, recognising the declining availability of this supply (established in the previous chapter). We draw together data from two Inquiry projects which addressed:

1. whether $\mathrm{Q} 2$ households trade off rental affordability for access to jobs, paying unaffordable rents in inner and middle regions which have the best access to a variety of jobs/industries (Hulse, Reynolds et al. 2019); and

2. whether Q2 private renter households are moving to outer suburbs and satellite cities in search of affordable rentals; creating additional commuting costs that risk weakening economic productivity (Dodson, Li et al. 2020).

To examine these possibilities, projects in the Inquiry investigated where Q2 households live relative to employment opportunities, employment status, commuting patterns, rental affordability, and their employment status. Due to data availability constraints it was necessary to examine commuting patterns of Q2 individuals in each of Sydney and Melbourne rather than households which have been the focus of the analysis thus far. We first ground our examination of the relationships between urban productivity, labour markets and affordable rental stock more closely through a spatial analysis of employment and housing geographies in Sydney and Melbourne. We then explore in greater detail the commuting patterns of individual Q2 workers and the location of different types of jobs, before turning to the more complex picture of housing choices made by Q2 households and implications for their rental affordability and employment status.

\subsection{Urban productivity, labour markets, and affordable rental housing}

As outlined in Chapter 1, urban productivity is enhanced by concentrations of workers and employers' access to a skilled labour market which in turn depends on the availability of affordable accommodation for workers. Rental housing in particular fulfils an important role in enabling workers to relocate to job-rich areas. When affordable rental housing is not easily accessible to jobs, households may endure an affordability burden-60 per cent of low-income working households are in housing stress (Productivity Commission 2019: 68); reduce their participation in the workforce-42 per cent and 32 per cent respectively of employed private renters in the first and second lowest income quintiles would like to work more hours (Productivity Commission 2019: 68); and/or endure long commutes to work.

In addition to the social costs (and environmental consequences in the case of car based commuting); each of these outcomes has potential implications for urban productivity. For instance, households may not be able to sustain housing affordability stress in the long term, implying higher levels of staff turnover and recruitment challenges for firms, draining productivity. Lower rates of labour market participation reduce the labour market pool, again, potentially reducing productivity. Lengthy commutes have productivity costs across the urban system, in terms of the lost time as workers sit in traffic and as goods take longer to transport.

In Australian cities, higher paying jobs in knowledge and service industries are historically located in central areas, which in turn are well served by public transport. Housing located in proximity to these areas is more expensive, and lower paid workers employed in central city areas will face affordability burdens or long commutes. However, service, retail sector, and construction/manufacturing jobs are likely to be more dispersed, while the geography of new and emerging innovation-led industries remains unclear. 


\subsection{The location of employment opportunities relative to affordable rental housing in Sydney and Melbourne}

An overriding narrative in discussions of productivity has been the concentration of jobs, particularly professional sector jobs, in the CBDs and inner urban regions of major cities due to processes of agglomeration (Glaeser and Gottlieb 2009; Maclennan, Ong et al. 2015; Dodson, de Silva et al. 2017). Research for this Inquiry reiterates previous findings that professional jobs in business service industries tend to be concentrated more strongly, often in the CBD and inner suburbs of Sydney and Melbourne; professional and semi-professional jobs in professional/scientific, public administration and education and training are found in clusters throughout the city; and semi-skilled and low skill jobs in administration/support, retail, accommodation and food services are quite widely dispersed through urban areas (see Hulse, Reynolds et al 2019: 14-15). Higher levels of part-time work and female employment are typically more dispersed throughout both capital and satellite cities (see also Cassidy and Parsons 2017), while accessibility to jobs from different locations seems to be greater in satellite cities.

Figures 6 and 7, adapted from analysis undertaken for Inquiry Project C, show the spatial patterns of employment density in Greater Sydney and Melbourne, in relation to the geography of affordable rental housing. For the purposes of this spatial analysis, areas with a median rental for a two bedroom property at $\$ 355$ per week or less were identified as an indicator of affordable rental markets, although it is important to note that this indicator does not show the total amount of rental stock $^{13}$, nor its availability to low-income households, as discussed in greater detail in the previous chapter. (Note that due to state reporting differences, rental affordability is reported by postcode for NSW and at SA2 level for Victoria).

As shown, both cities demonstrate employment density clustering within 30 kilometres of the CBD, dispersing along major rail lines/transportation routes. As expected, there is an almost inverse relationship between the geography of employment density and affordable rental housing stock, reflecting the premium in Australian cities for housing which is accessible to employment opportunities.

13 Corresponding with the $\$ 355$ per week upper level affordable rent for Q2 households in the analysis in Chapter 2 (although no size/type of accommodation was specified in that analysis). 
Figure 6: Employment density and private rental housing affordable to Q2 households 2016, Greater Sydney

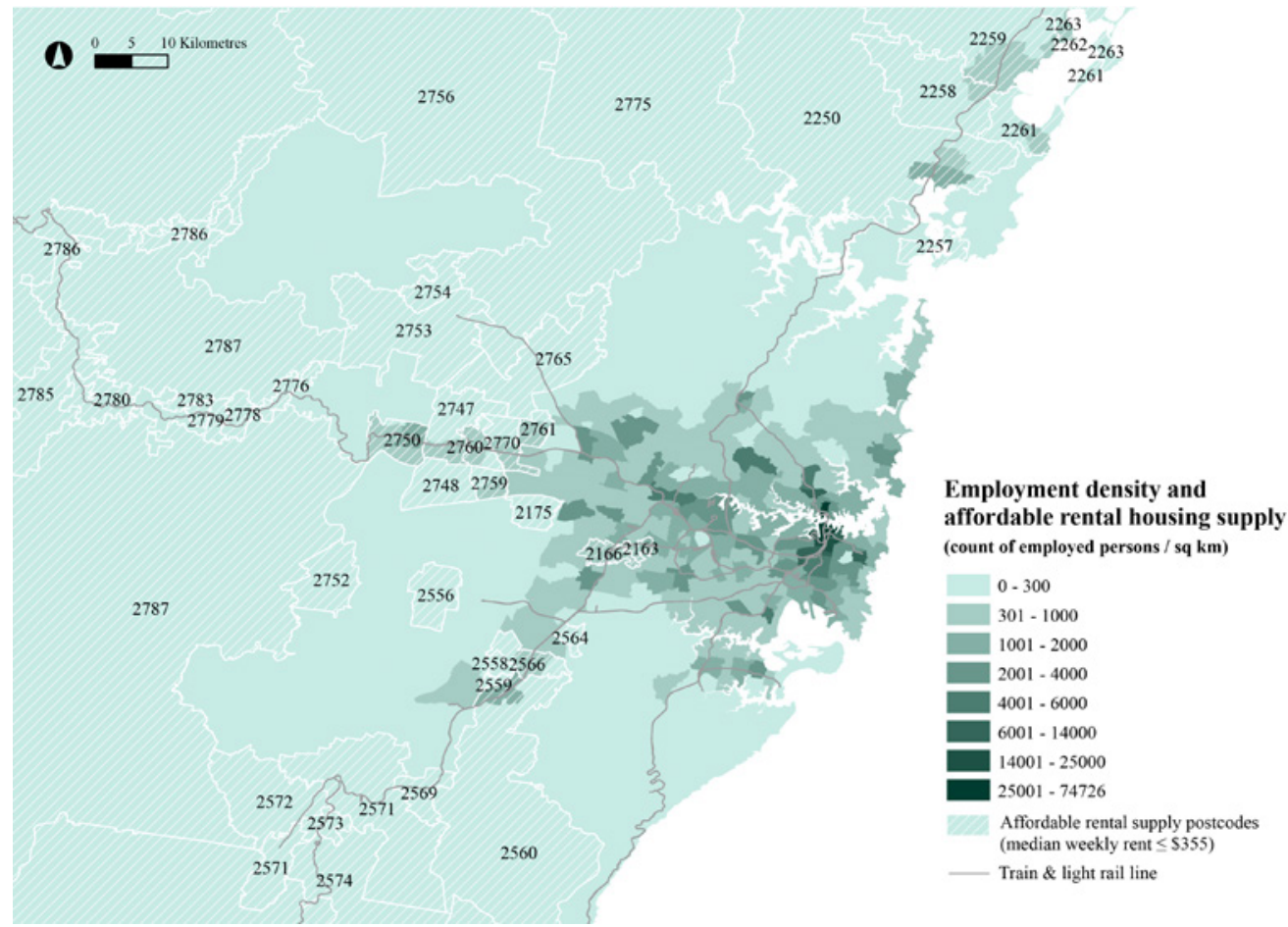

Source: Adapted from Pill, Gurran et al. 2020 and drawing on Fair Trading, NSW Government 2016; ABS Census 2016 TableBuilder - Counting Employed Persons, at Place of Work (employment); OpenStreetMap (train and light rail line).

Figure 7: Employment density and private rental housing affordable to Q2 households 2016, Greater Melbourne

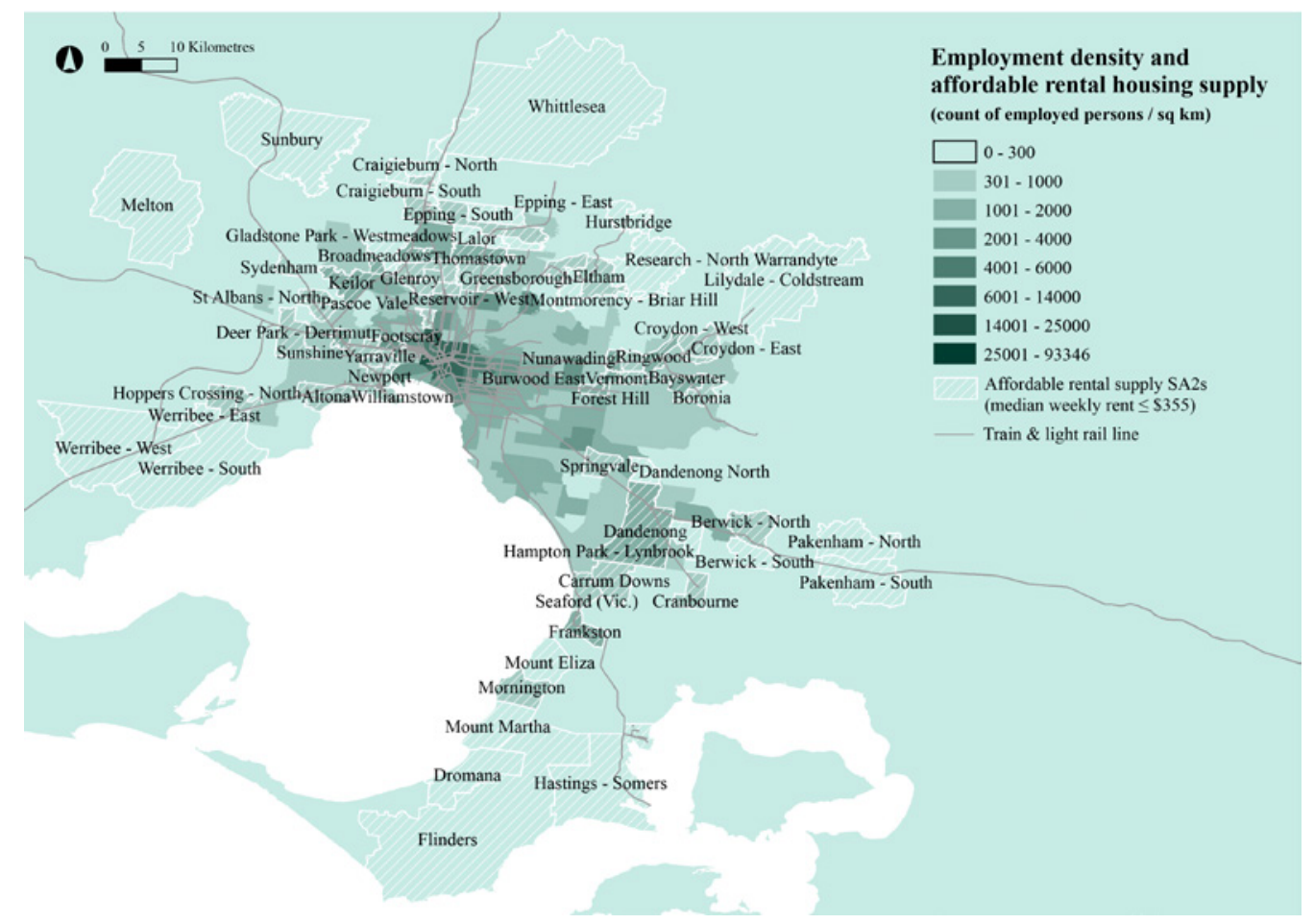

Source: Adapted from Pill, Gurran et al 2020 and drawing on Rental Reports, Victoria State Government, 2016; ABS Census 2016 TableBuilder - Counting Employed Persons, at Place of Work; OpenStreetMap (train and light rail line). 
This spatial dichotomy raises four questions:

- whether low-income rental households are forced into long commutes to reach their place of work

- whether low-income workers are paying unaffordable rents to improve their accessibility to employment opportunities

- whether the particular jobs accessed by these Q2 workers are actually located in proximity to their housing; noting that where households are concerned, there is likely to be joint decision making about where to live with one partner trading off employment opportunities (i.e. accepting a part-time or lower skilled job) in order to live closer to home, and

- whether some low-income households have low levels of employment participation overall, potentially due to their inability to access opportunities because of where they live.

We address these questions in turn in the sections below.

\subsection{Do Q2 workers have longer commutes to work than other groups?}

Project B for this Inquiry examined the commuting patterns of individual Q2 renter workers. The findings of this analysis were surprising, notwithstanding the fact that some Q2 renter workers may be part of a moderate to higher income household, giving them more housing choices than those in lower income households. Methodologically however it is not possible to link individual commuters to the household of which they are a member, using Census data, thus this dimension cannot be adequately considered.

On average, Q2 renter workers in Sydney and Melbourne have a shorter journey to work than that of all commuters in both cities, travelling $10.1 \mathrm{~km}$ in Melbourne and $9.3 \mathrm{~km}$ in Sydney. This is in part because Q2 renter workers jobs are dispersed and more likely to be outside of the CBD, thus not necessitating long trips. While many Q2 renter workers are employed in jobs located in the CBDs of Melbourne and Sydney, the mode of travel to these sites is likely to be by public transport, thus relatively cost efficient per kilometre of travel. However, a sizeable proportion of Q2 renter workers do have high commuting burdens (discussed further, and shown in the figures below).

The commuting pattern for Q2 renter workers in Sydney is highly centralised. The highest trip concentration is found in the Sydney CBD and surrounding areas (Ultimo and Alexandra). These places in total offered 40 per cent of jobs for Q2 renter workers who experience high commuting burdens. The second significant, albeit smaller, cluster of commuting movements is in the far north of the metropolitan region near Gosford. There are high levels of commuting movements and interactions within this region, which in aggregate form strong self-contained labour and job markets. Notably there is relatively little commuting by Q2 renter workers across the Hawkesbury River.

Most major commuting flows in the Melbourne metropolitan area exhibit a polycentric structure with clear regional differentiation. The Melbourne CBD is the principal destination for Q2 renter worker commuters, with flows from the west and the south-east particularly pronounced. Notably relatively few Q2 renter worker commuters travel to the Melbourne CBD from the northern suburbs or from the southern bayside suburbs. Melbourne exhibits three further clusters of Q2 renter worker commuting destinations within Laverton North in the west, Clayton-Dandenong in the south-east and Frankston in the bayside outer south-east. Renter workers in Q2 travelling to these areas typically commute over a long distance, many of them by car. 
Figure 8: Journey to work trips for Q2 renters in Sydney with high commuting burdens

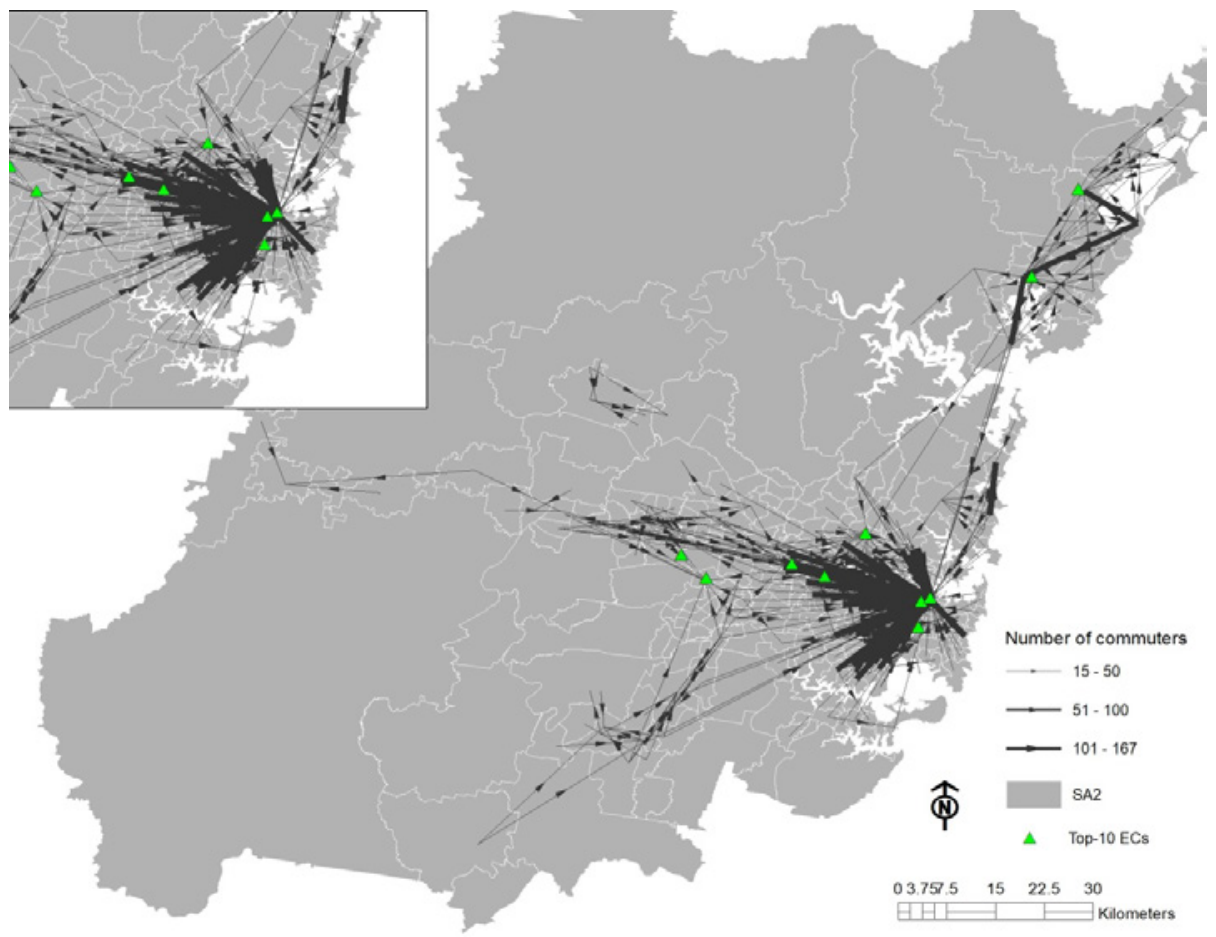

Source: Dodson, Li et al. 2020.

Figure 9: Journey to work trips for Q2 renter workers in Melbourne with high commuting burdens

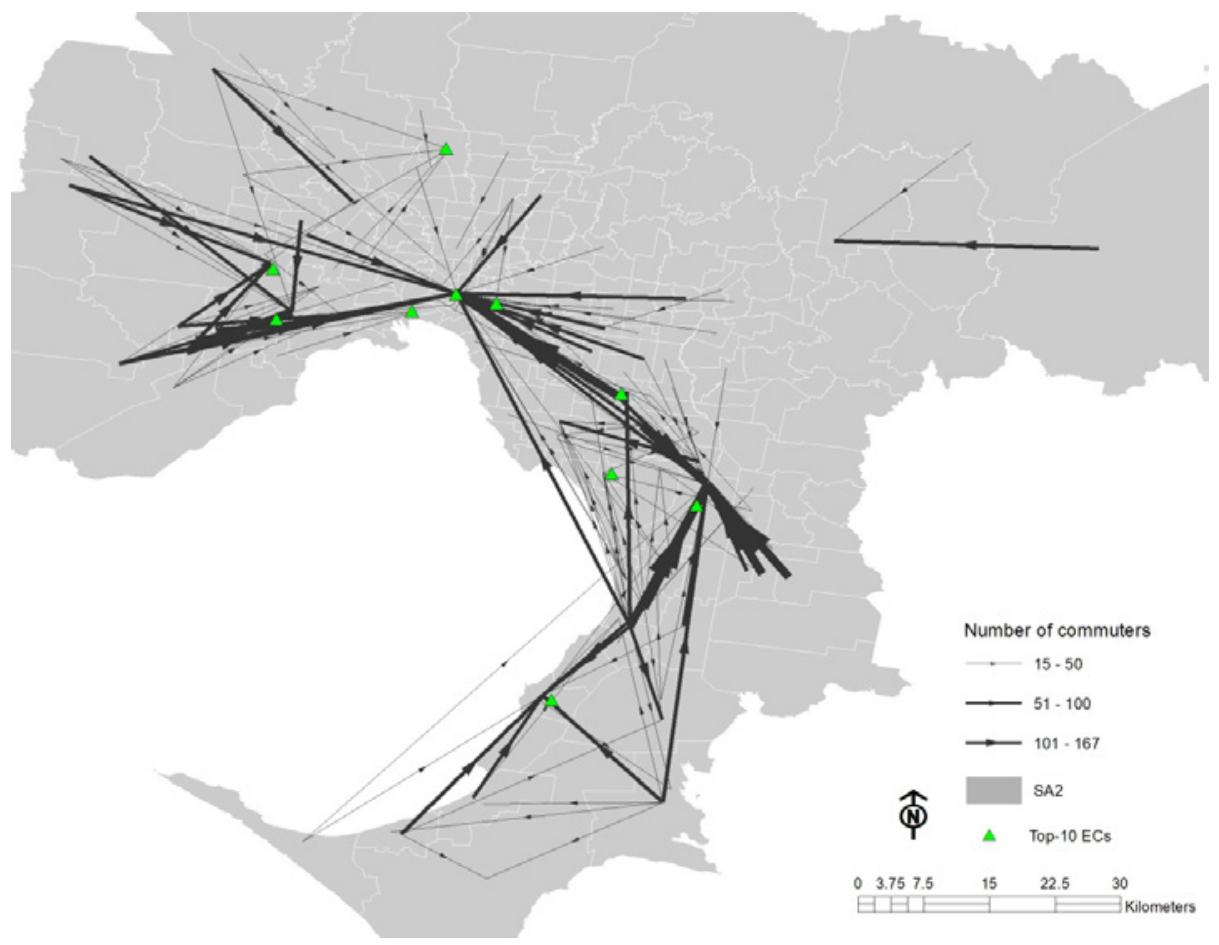

Source: Dodson, Li et al. 2020. 
Thus, many Q2 renter workers with high commuting burdens are travelling to the major employment centres in each city (e.g. CBD, Monash and Parramatta). These Q2 renter workers are typically skilled and contribute to the agglomeration economy in Australia's large cities.

It is important to note that evidence collected for this Inquiry found that households are seeking to minimise either housing cost or commuting cost to manage their total living expenses. Nevertheless, the analysis found that many Q2 renter workers appear to be paying both higher housing rent and enduring a high commuting cost (involving both time as well as vehicle, fuel or public transport expenses). This combined housing and transport costs reduces net wages, placing households under high economic burden, increasing the risk that workers in these situations will be less productive. Household effects (i.e. where another member of the household is a higher income earner) may moderate this risk however.

\subsection{Q2 workers in satellite cities}

In addition to examining relationships between where Q2 renter workers live and work in Sydney and Melbourne, the project also examined two growing satellite cities in Australia: Wollongong to Sydney's south east; and Geelong, south west of Melbourne. The purpose of this analysis was to examine the existing and potential role of satellite cities in offering affordable rental accommodation for Q2 renter workers with accessibility to local employment opportunities and/or to job markets in Sydney and Melbourne.

With respect to Wollongong, the analysis found that most Q2 renter workers in Wollongong live and work within the region. Some workers travel to work in the surrounding regions, and a smaller proportion commute to the Sydney CBD or other employment areas of Sydney. Overall, there appears to be a high level of jobs/housing balance in Wollongong and self-containment in the housing and employment market. Wollongong East attracts the highest number of commuters in the region.

Similarly, most Q2 renter workers in Geelong travel to work within the Geelong region. Some undertake longer commutes to nearby the outer south-western suburbs of Melbourne, and some industrial zones in Melbourne's south east such as Dandenong. However, unlike the larger volume of professionals at higher income levels who commute to Melbourne's CBD, the commuting interaction of Q2 renter workers between Geelong and Melbourne is not very strong. Geelong CBD attracts the highest level of Q2 renter workers in the region.

These results indicate that Q2 renter workers living in the satellite cities of Wollongong and Geelong have been able to access relatively affordable accommodation near their employment. This means that they do not experience the affordability pressures and commuting burdens of their counterparts in Sydney or Melbourne. Although it was not investigated directly, we might assume that the relatively lower wages earned by Q2 renters motivate local work trips rather than long distance travel to a larger job market such as Melbourne. The wider availability of employment opportunities in these satellite cities has recently been in question however, due to de-industrialisation, in particular of the manufacturing industry. Notably, the effects on employment and commuting patterns arising from the shutdown of the automotive sector in Geelong in late 2017 were too recent to be recorded by the 2016 ABS Census on which this study is founded.

To investigate further the ways in which the geographies of employment and affordable housing opportunity intersect, in the following section we consider the spatial distribution of specific types of jobs and industries across metropolitan and satellite city areas.

\subsection{Patterns of job concentration and dispersion}

The evidence presented above shows a moderate spatial mismatch between the location of employment opportunities (as measured by the density of jobs) and of rental housing affordable to lower income households (indicated by small area median rents), as measured by Census data. This generally aligns with Dodson's (2005) findings on spatial mismatch in Melbourne where the market values accessibility to transport and employment opportunities, so more accessible areas will typically cost more to rent or buy (Dodson 2005). However, not all industries (or professions) have the same patterns of spatial concentration. Although the concentration of highly skilled and paid jobs within CBDs is continuing in Australian cities, spatial analysis reveals that other industries 
and occupations are distributed in different ways. Although this project focused on Q2 renter workers as a single group, it may be the case that there is differentiation within this cohort, between, for example, early-career professionals on entry level salaries who work in the CBD and workers in non-professional occupations who work in suburban locations.

Project A in this Inquiry examined where jobs are located, focusing on the extent to which different types of jobs are spatially concentrated or dispersed. It calculated the index of 'dissimilarity' to show differences in the distribution of employment opportunity, relative to other industries and occupations across Melbourne, Sydney and their satellite cities. Shown in Table 2 below with reference to industries, the dissimilarity index here ranges between 0 and 1 , with a higher value indicating a more concentrated spatial distribution of jobs and a lower value indicating a more dispersed distribution.

Table 2: Spatial concentration of jobs by industry (dissimilarity index), Sydney, Melbourne and satellite cities, 2016

\begin{tabular}{|c|c|c|c|c|}
\hline & Sydney & Melbourne & Wollongong & Geelong \\
\hline Admin \& Support & 0.15 & 0.16 & 0.14 & 0.09 \\
\hline Construction & 0.25 & 0.26 & 0.23 & 0.13 \\
\hline Retail Trade & 0.28 & 0.28 & 0.21 & 0.20 \\
\hline Accommodation \& Food & 0.20 & 0.22 & 0.21 & 0.15 \\
\hline Professional, Scientific and Technical Services & 0.35 & 0.34 & 0.21 & 0.18 \\
\hline Public Admin \& Safety & 0.36 & 0.38 & 0.42 & 0.30 \\
\hline Education \& Training & 0.34 & 0.35 & 0.35 & 0.29 \\
\hline Manufacturing & 0.47 & 0.50 & 0.55 & 0.27 \\
\hline ITC \& Media & 0.45 & 0.43 & 0.29 & 0.25 \\
\hline Finance \& Insurance & 0.58 & 0.52 & 0.45 & 0.38 \\
\hline
\end{tabular}

Note: dissimilarity index is calculated at SA2 level for each capital and satellite city.

$D I S=$, where $n$ is number of spatial units, $i$ is an index of spatial units, $J$ is number of jobs in a particular industry or occupation (Ji is thus number of particular jobs in a given SA2), $T$ is the total number of jobs by industry or occupation in a city (Ti is thus the total number of particular jobs in a city), and $\mathrm{K}$ is the total number of jobs (minus $\mathrm{J}$ ).

Source: Hulse, Reynolds et al. 2019: 68, Table 14.

As shown, administration and support, retail trade, and accommodation and food services, all industries associated with higher shares of part-time and female employment, are typically more dispersed throughout both capital and satellite cities. Other jobs in knowledge intensive and government sectors (professional/scientific, public administration, education and training) are moderately concentrated, while business service jobs (ICT, media, finance and insurance) are highly concentrated. Manufacturing jobs also tend to be highly concentrated.

In general, Sydney has the highest concentration of knowledge industry and professional jobs, while Geelong demonstrates the highest degree of job dispersion. Similar patterns were found when the spatial distribution of jobs by occupation was examined. In short, part-time and lower skilled workers may have access to employment opportunities across a wider urban geography than the central locations where higher paying and highly skilled knowledge, public sector, and finance industries concentrate. This helps explain the finding that average Q2 renter workers have comparatively shorter commutes.

The spatial geography of jobs distribution was also examined in Inquiry Research Project C. Extending this work, Figures 10 and 11 show spatially the highest industry of employment sector relative to the location of affordable rental housing supply in Sydney and Melbourne. As shown in Figure 10, there is a clear spatial mismatch between the locations of affordable rental housing (towards the north and south west of the city) and higher employment locations in Sydney (the east and middle rings). This mismatch is less pronounced in Melbourne (Figure 11), but the absence of affordable rental housing in central and middle ring suburbs which are also the primary employment locations in Melbourne, is still apparent. 
Figure 10: Geography of occupations and affordable rental housing supply, Greater Sydney

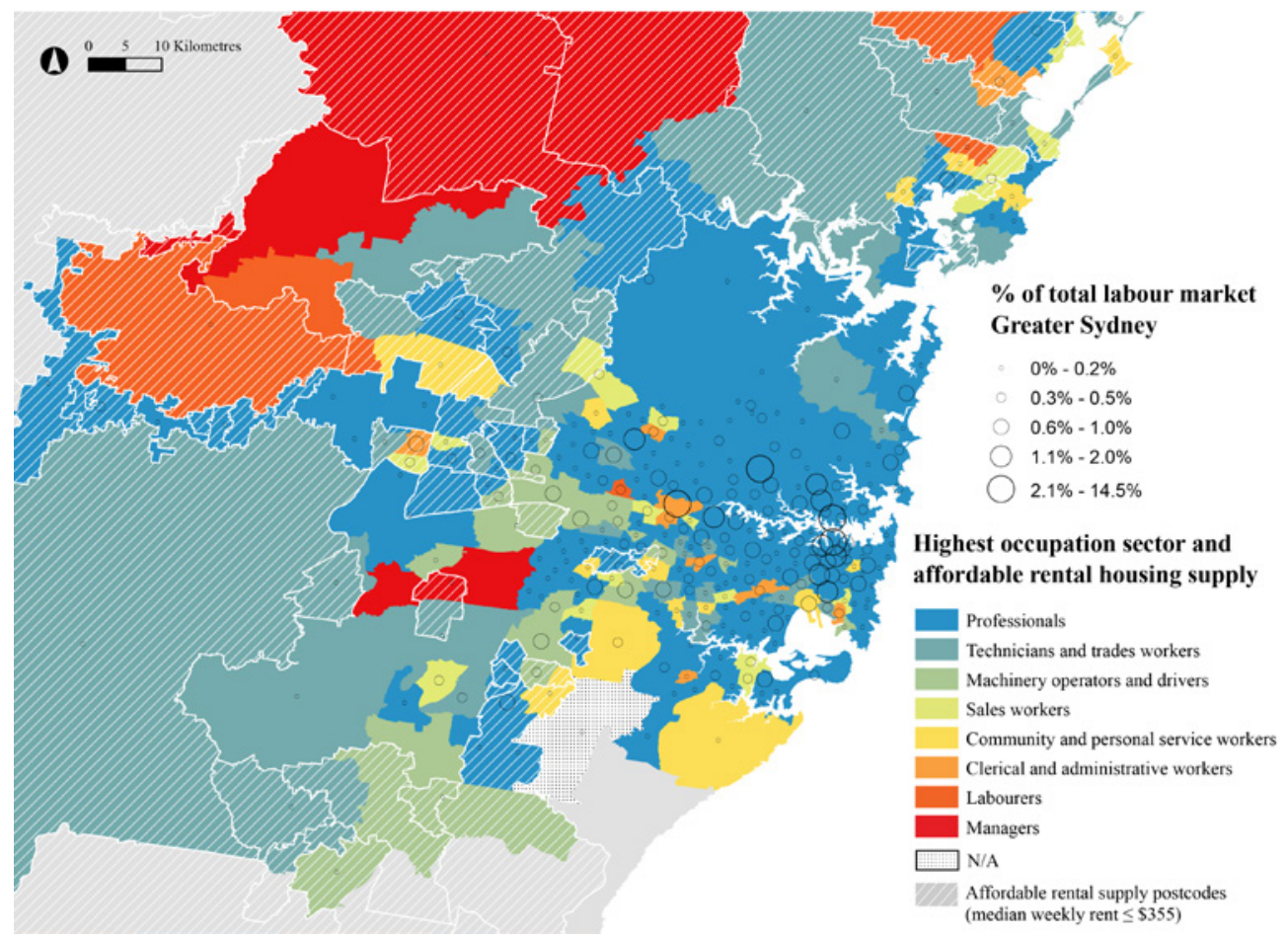

Source: ABS Census 2016 TableBuilder - Counting Employed Persons, at Place of Work, by OCCP Occupation.

Figure 11: Geography of occupations and affordable rental housing supply, Greater Melbourne

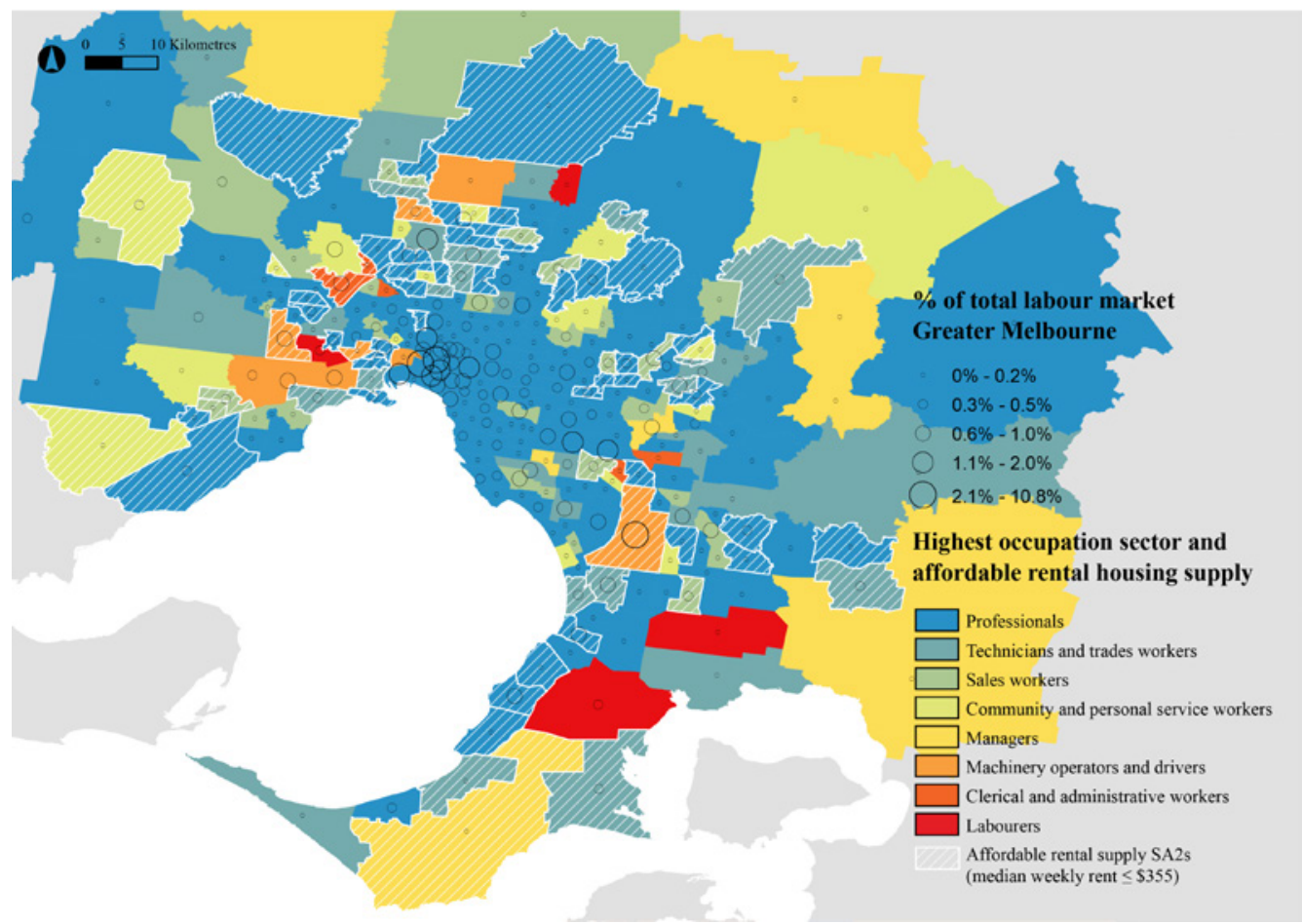

Source: ABS Census 2016 TableBuilder - Counting Employed Persons, at Place of Work, by OCCP Occupation. 
As suggested above (see Figure 10 and Figure 11), this analysis implies a closer spatial sorting between employment industries and different types of occupation and rental housing submarkets, with lower value rental markets appearing in localities where lower paid and lower skilled employment opportunities dominate. The spatial dispersal of lower paid employment opportunities across Sydney, Melbourne, and their satellite cities is one factor to help explain why many lower income workers experience average or below average commute distances.

Considering occupation types (places of work), lower income jobs such as labourers, technicians and trades workers, machinery operators and drivers made up a larger proportion in non-central, less dense suburbs, with higher-income jobs such as professionals taking a larger proportion in the inner city, where rents are relatively high. The areas with affordable rental housing supply match areas with lower income employment, indicating some spatial proximity between lower-rent housing and lower paid work opportunities. Notably however, the size of employment markets in these lower value areas is also much smaller as a proportion of the city's total jobs.

Figures 12 and 13, prepared for this report, show the distribution of jobs by occupation in the satellite cities of Wollongong and Geelong alongside the locations of affordable rental housing. The analysis found higher diversity in occupations at the small area scale in both cities, consistent with the overall 'dissimilarity' index, as shown above. For this reason, all of the major job occupations and their distribution are represented.

Figure 12: Geography of occupations and affordable rental housing supply, Wollongong

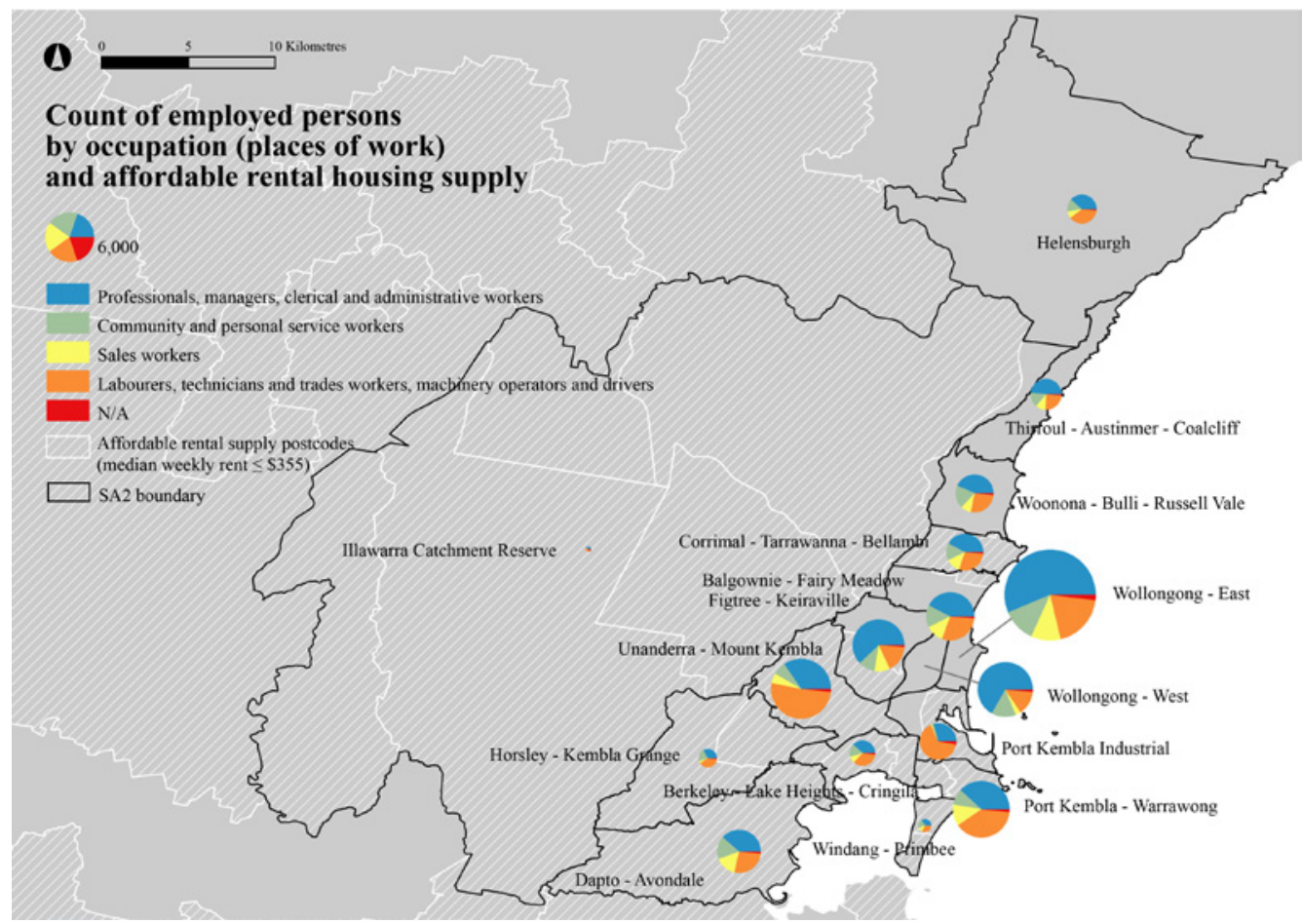

Source: Authors, data derived from ABS Tablebuilder 2016. 
Figure 13: Geography of occupations and affordable rental housing supply, Geelong

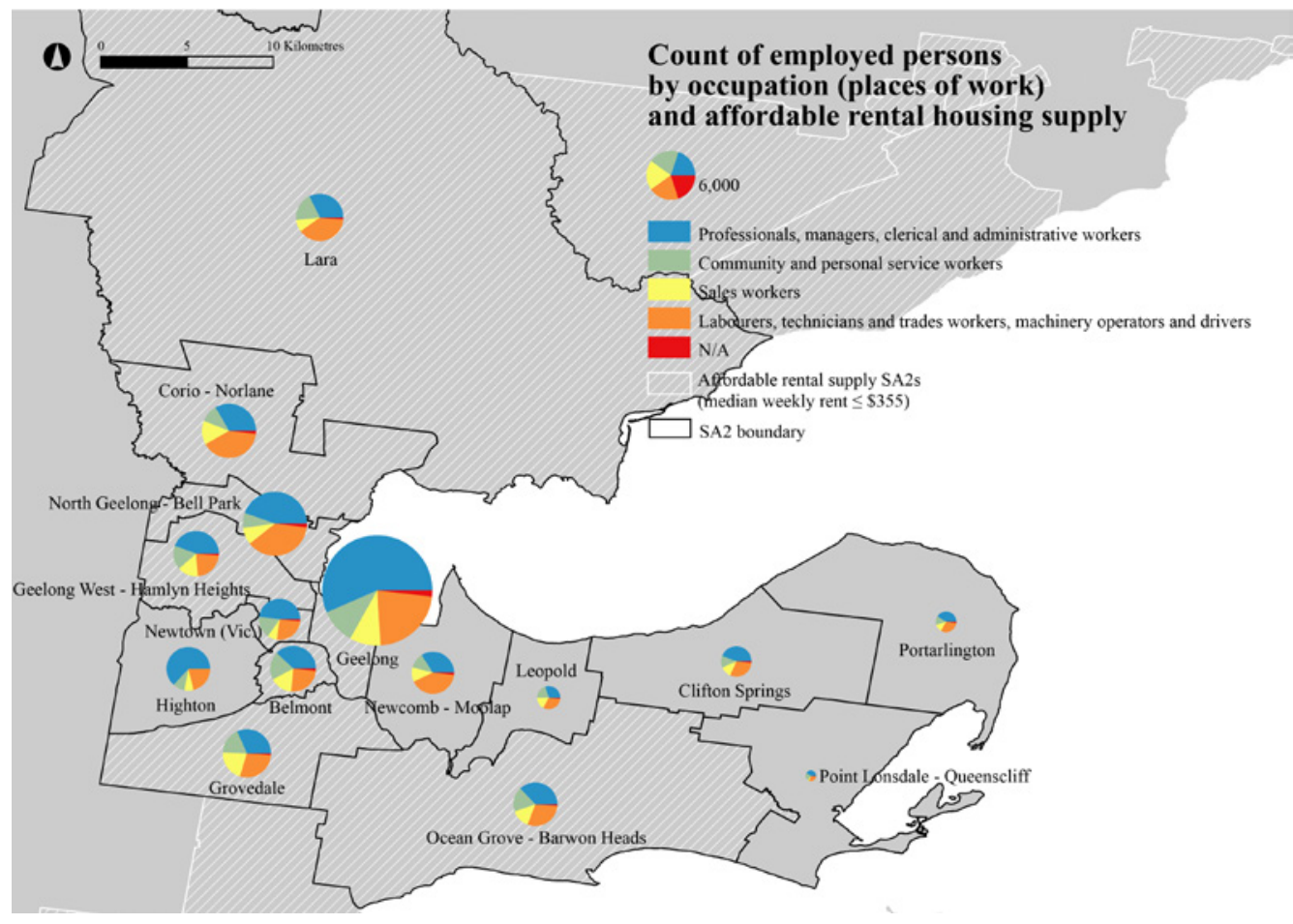

Source: Authors, data derived from ABS Tablebuilder 2016.

In summary, the evidence so far shows that some industries are more dispersed across the metropolitan regions of Sydney and Melbourne than others, and that those industries that are dispersed are likely to include part-time, lower skilled, and lower paid employment opportunities and include jobs in which women predominate, such as retail and clerical jobs. Further, these locations are more likely to be situated near lower cost rental submarkets, although the availability of affordable accommodation in these areas remains under supplied.

How does this spatial geography influence employment opportunities and outcomes? The following sections consider further the intersections between access to affordable rental housing and employment status.

\subsection{How does access to affordable rental housing intersect with the employment status of Q2 households?}

This section examines whether there are discernible differences in the rental affordability status of Q2 private renter households and their employment status, focusing on Sydney and Melbourne and their satellite cities. The analysis is exploratory and provides statistical aggregates based on ABS Census data at one point in time (2016).

\subsubsection{Employment status of private renter households by quintile}

We first examine the employment status of Q2 households, showing how this compares with Q1 and Q3 households. Table 3 summarises the employment and socio-demographic status for Q1, Q2, and Q3 households in Australia, as of the 2016 Census. It shows that workforce participation is lowest amongst Q1 households; with more than 50 per cent either not in the workforce or seeking work. By contrast, only one in five Q2 households have no members in the workforce. This group includes more households in the 25-44 year old age bracket, but also more families with children (particularly single parents).

The demographic characteristics of households influence their capacity to engage in the workforce. Parents, and single parents with dependent children, may face particular constraints with travelling long distances to work. 
Table 3: Employment and socio-demographic status for Q1, Q2 and Q3 households, 2016, Australia

\begin{tabular}{|c|c|c|c|}
\hline $\begin{array}{l}\text { Household } \\
\text { income status }\end{array}$ & Employment status & Socio-demographic status & $\begin{array}{l}\text { Potential to increase } \\
\text { employment participation }\end{array}$ \\
\hline Q1 & $\begin{array}{l}\text { - Predominantly not in the labour } \\
\text { force (56\%) or have one part- } \\
\text { time earner (18.9\%). } \\
\text { - One in seven households (15.2\%) } \\
\text { has a job-seeking member. }\end{array}$ & $\begin{array}{l}\text { Widely spread across the age } \\
\text { spectrum with the most common } \\
\text { types being working age people } \\
\text { living alone (36\%) and single } \\
\text { parent families (22\%). There are } \\
\text { few couple households (17\%). }\end{array}$ & $\begin{array}{l}\text { Single adults with or without } \\
\text { children moving into work or } \\
\text { being able to work more hours, } \\
\text { noting that many single parent } \\
\text { households are female-headed. }\end{array}$ \\
\hline Q2 & $\begin{array}{l}\text { - Predominantly have one full-time } \\
\text { earner (33.6\%) or one part-time } \\
\text { earner (15.9\%). One in five (19.6\%) } \\
\text { of Q2 household have no members } \\
\text { in the labour force. } \\
\text { - One in } 12 \text { households ( } 8.3 \%) \\
\text { has a job-seeking household } \\
\text { member. }\end{array}$ & $\begin{array}{l}\text { More households in the } 25-44 \\
\text { year old age bracket (51\%) and } \\
\text { fewer older households. More } \\
\text { families with children (39\%) } \\
\text { - mainly single parents (22\%). } \\
\text { More than half are working } \\
\text { age households with one adult } \\
\text { - either single parents or people } \\
\text { aged 15-64 living alone. }\end{array}$ & $\begin{array}{l}\text { Adults not in the labour force } \\
\text { entering paid work and/or } \\
\text { part-time workers working } \\
\text { more hours, noting the high } \\
\text { percentage of single parent } \\
\text { predominantly female-headed } \\
\text { households (22\%). }\end{array}$ \\
\hline Q3 & $\begin{array}{l}\text { - Predominantly single full-time } \\
\text { earner (31\%) or couple households } \\
\text { with one full-time and one part- } \\
\text { time earner (18.3\%) or partner } \\
\text { not in the labour force (15.7\%). } \\
\text { Only one in } 15 \text { (6.5\%) of these } \\
\text { households has a job-seeking } \\
\text { household member. }\end{array}$ & $\begin{array}{l}\text { - Typically, younger than either } \\
\text { Q1 or Q2 households-71 per } \\
\text { cent are aged } 44 \text { and under. } \\
\text { More couple households (53\%). } \\
\text { Forty-five per cent have children } \\
\text { (one and two adult families). }\end{array}$ & $\begin{array}{l}\text { Second adult in households may } \\
\text { be able to enter the labour force } \\
\text { or work more hours. Likely to be } \\
\text { household decision-making about } \\
\text { employment participation that } \\
\text { can accommodate caring and } \\
\text { other responsibilities. }\end{array}$ \\
\hline
\end{tabular}

Source: Adapted from Hulse, Reynolds et al. 2019: 53, Table 7; 65, Table 12.

It is clear from Table 3 that the potential for greater employment participation by Q2 households is for adults not in the labour force entering paid work and/or part-time workers working more hours, noting the high percentage of single parents in the latter group. This contrasts with Q3 households where potential for greater employment participation is for partners in couple households to enter paid work or work more hours.

\subsubsection{Employment status and rental affordability status}

Census data do not allow us to determine whether the observed supplied labour is an active choice or whether these households want to work more but cannot obtain more work (involuntary unemployment); or it is financially unprofitable to obtain additional work hours, and therefore might be considered under-employment. However, it is notable that a relatively large proportion of Q1 households are job-seeking and without any earned income. Similarly, there is a relatively large proportion of Q1 and Q2 households that primarily have part-time paid income.

When we start to tease out the link between employment status and rental affordability, we find unsurprisingly for all PRS households nationally, there is a steep gradient, with households with two full-time workers having the lowest rates of rental unaffordability, and those with no members in the labour force having the highest rates (Figure 14 Panel A) If we look specifically at Q2 households (quasi standardising for household income) (Figure 14 Panel B), this gradient almost disappears.

With the exception of two full-time earner households (nearly half of these rent unaffordably), some 30-40 per cent of the remaining Q2 households rented unaffordably. Hulse, Reynolds et al. (2019) show that the shortage of affordable and available housing options for Q2 renters has increased since the late 1990s. Moreover, affordability issues have also moved further up the income scale over the period 2011-16, as discussed in Chapter 2. This is a broad national picture: the next step is to examine in what ways changes in affordable rental supply within Sydney and Melbourne and in their satellite cities may be associated with employment status. 
Figure 14: Employment status of 'all' renter households and Q2 renter households living in affordable/ unaffordable rental housing, Australia, 2016

a) All PRS households

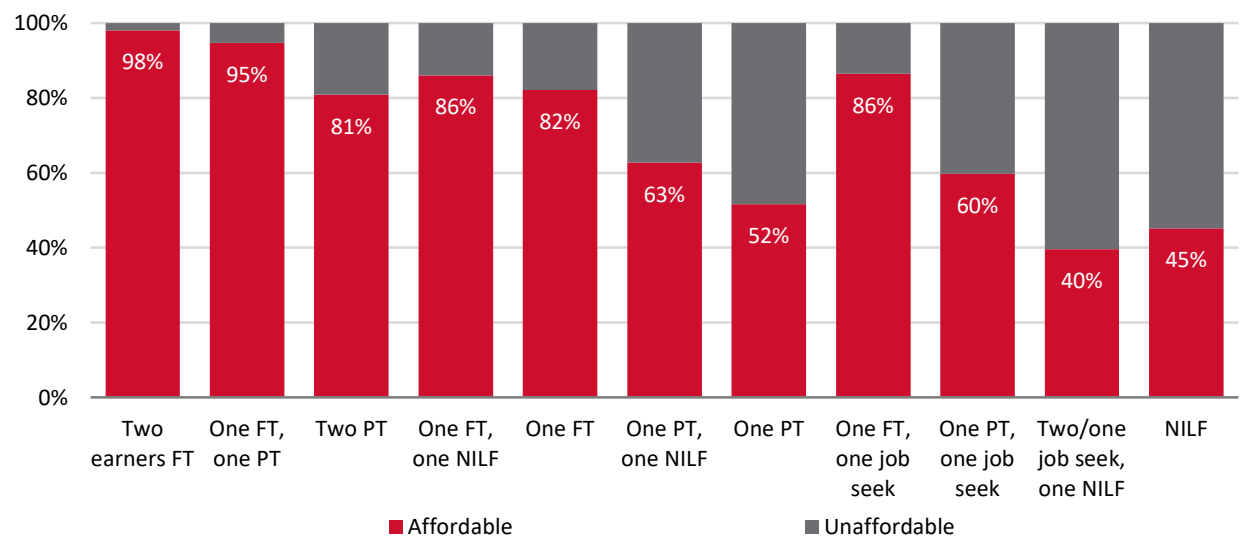

b) Q2 PRS households

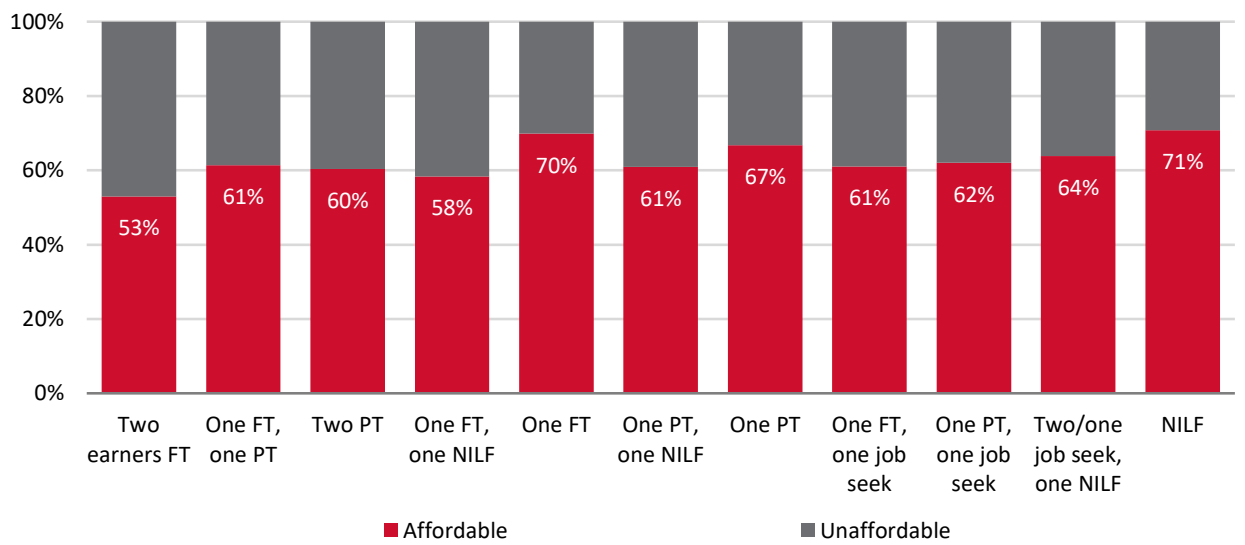

Note: The individual bars show affordability outcomes and household employment status. FT = full-time; PT = part-time; NILF= not in labourforce.

Source: Hulse, Reynolds et al. 2019: 66, Figure 17.

\subsubsection{Q2 private renter households by employment status and rental affordability outcomes: Sydney, Melbourne and satellite cities, 2016}

Within the constraints of point-in-time statistical aggregates, Project A for the Inquiry investigated differences in employment status between those renting affordably and renting unaffordably in each of the household income quintiles and by regions. The findings suggest that the differences in employment status between those renting affordably and renting unaffordably in each of the income quintiles and within inner/middle/outer Sydney and Melbourne and their satellites are minor, most likely reflecting variation in hourly wages or detailed hours worked, rather than evidence towards understanding spatial mismatch and trade-offs (Hulse, Reynolds et al. 2019: 75). However, aggregate statistics can still provide some insights when comparing across areas:

- Differences between inner, middle and outer areas of capital cities can provide an indication of whether a trade-off between housing affordability and proximity to jobs might exist within capital cities.

- Differences between capital cities and satellite cities provide an indication of whether relocation to a satellite city provides an alternative to remaining in outer suburbs of capital cities.

We explore this issue through examining the employment status and location of Q2 private renters living affordably and unaffordably in inner, middle and outer suburbs of Sydney and Melbourne and in their satellite cities (Figures 15 and 16). 
Figure 15: Q2 PRS household employment status in affordable and unaffordable rental, Sydney and satellite cities

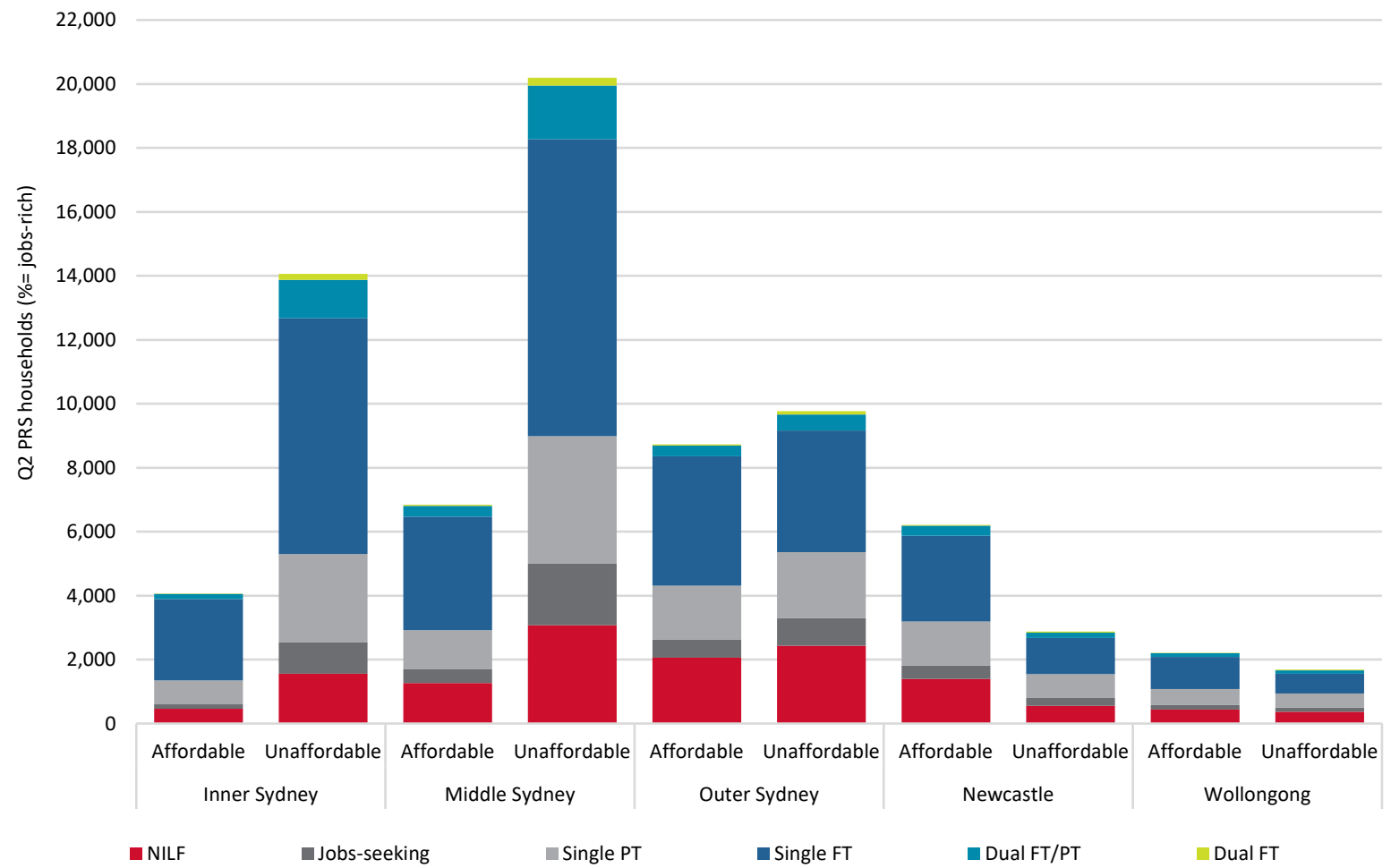

Source: Hulse, Reynolds et al. 2019: 77, Figure 21A.

In Sydney (Figure 15), there is a relatively large number of Q2 private renter households, the majority of whom have single full-time income earners, living in the inner and middle suburbs, in what appear to be predominantly unaffordable rentals. These suburbs provide access to the greatest concentration and range of jobs and it appears that these households are trading off rental affordability for the access to jobs offered by the well-placed middle suburbs or access to inner suburbs, at least for the moment. Of course, a range of other factors may also be important in their decision making, such as access to schools, transport, and family and friends. Further we do not know how long they can sustain these high rental burdens unless they are able to increase their household incomes through increasing their hourly rate/s or working more hours.

In Melbourne the picture is a bit different (Figure 16). There are higher numbers of Q2 private renters living in the middle and outer suburbs and higher percentages living in affordable rentals, which as we saw earlier in the chapter are in greater supply, particularly in the outer suburbs of Melbourne. It appears that the extent of trading off rental affordability for location is lower in Melbourne than in Sydney. It could be that jobs are more dispersed across Melbourne than in Sydney and/or that access to transport and facilities is better across the middle and outer suburbs, or a range of other factors such as access to schools, have increased access to rental housing that is affordable to Melbourne's lower income earners. 
Figure 16: Q2 PRS household employment status in affordable and unaffordable rental, Melbourne and satellite city

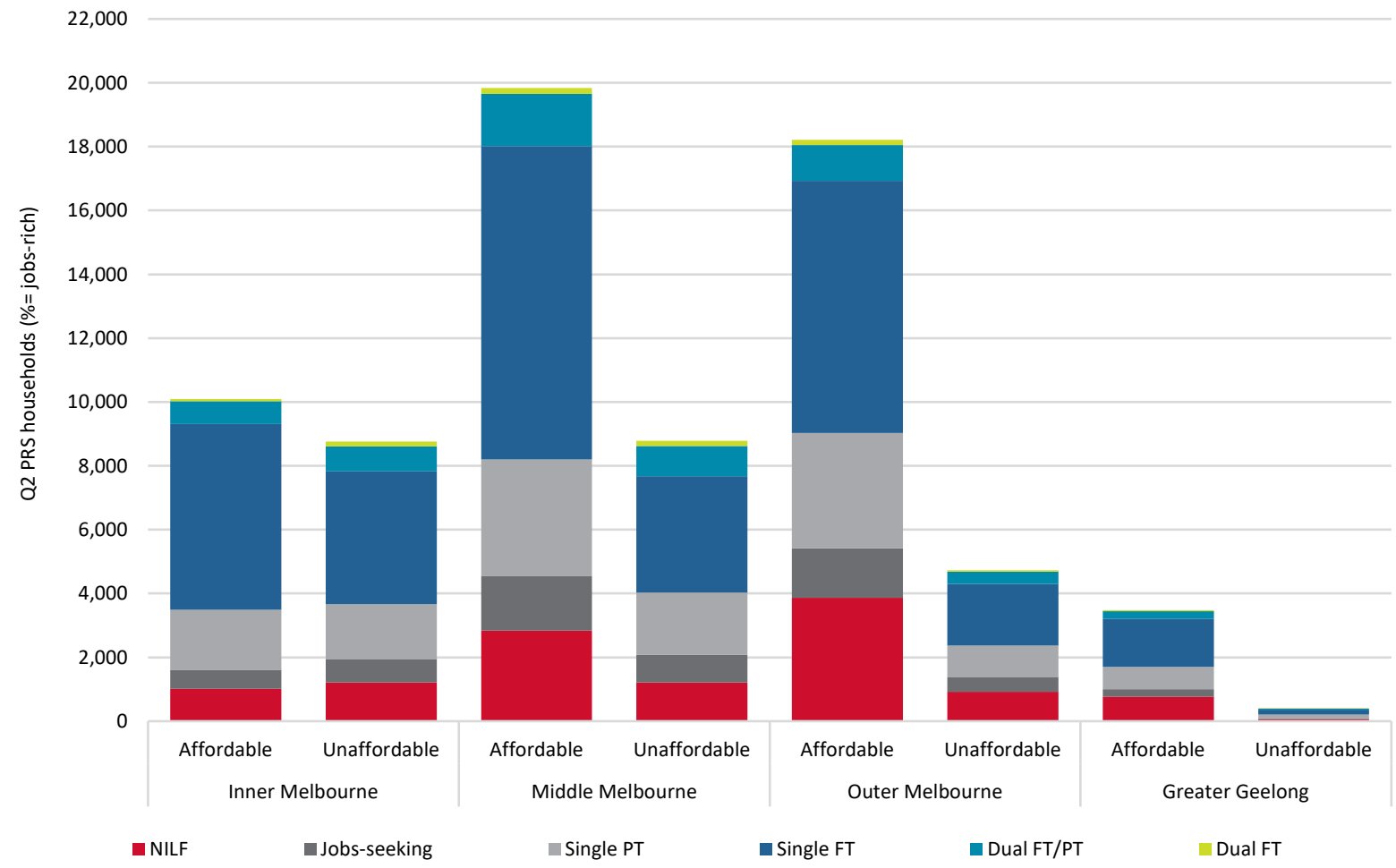

Source: Hulse, Reynolds et al. 2019: 78, Figure 22A.

Finally, the difference in affordability outcomes for Q2 private renters in affordable and unaffordable private rental irrespective of their employment status is largely the same across outer parts of Sydney and Melbourne and their respective satellite cities. There is little indication from this macro-analysis that households in a capital city are likely to improve their rental affordability outcome significantly by relocating to satellite cities (Hulse, Reynolds et al. 2019).

We note that other research has suggested that access to jobs is more about individual characteristics, rather than neighbourhood or area characteristics (Productivity Commission 2015; Labour Market Research and Analysis Branch 2019). Our research suggests that household level factors are also likely to be important when making decisions about where to live and work. For example, many Q2 and Q3 private renter households have children living with them (Hulse, Reynolds et al. 2019: 53, Table 5), so access to child care and schools is likely to be a factor. As discussed earlier, much of the potential increase in employment participation for Q2 and Q3 is by couple and single parent households with children.

The findings support the idea that decisions about employment participation are likely to involve more than a calculation of the financial returns of working, and also be influenced by the logistics of work/home arrangements that are manageable for the households, combined with caring and other responsibilities (Saugeres and Hulse 2010). This fits with ABS data mentioned earlier that the highest rates of underemployment are among young people aged 15-24 and women in all working age cohorts (ABS 2016). 


\subsection{Summary and policy implications}

The chapter has further examined the implications for urban productivity of the rising dependence on the private rental market by Australian low-income households and workers as well as the growing shortage of rental stock that is affordable and available to this cohort.

First, we considered the evidence on whether the spatial mismatch apparent between areas rich in employment opportunities and localities offering affordable rental housing is resulting in increased commuting patterns by Q2 workers in Sydney and Melbourne. We found that some workers experience very long commuting times, representing a productivity drain. However, the analysis also showed that many low-income workers do not face longer than average commutes to work, reflecting four further possibilities significant to urban productivity:

a. that some low-income workers are paying unaffordable rents to improve their accessibility to employment opportunities

b. that the particular jobs accessed by these Q2 workers are located in proximity to their housing

c. that where households are concerned, there is likely to be joint decision making about where to live, with one partner trading off employment opportunities (i.e. accepting a part-time or lower skilled job) in order to live closer to home, or

d. that some low-income households have low levels of employment participation overall, potentially due to their inability to access opportunities because of where they live.

Further analysis showed firstly, that there is a high incidence of affordability stress amongst Q2 households who appear to favour housing in accessible locations. This would indicate that in Sydney, and to some extent in Melbourne, Q2 renter households in paid work are opting to live in apparently unaffordable rentals in inner and middle areas of these cities, which may give them the greatest access to a range of jobs/industries.

Secondly, the evidence suggests some spatial dispersal of certain types of occupations, in Sydney, Melbourne, and to a greater degree, in Geelong and Wollongong, which may offset commuting and rental burdens for Q2 households. Thirdly, the data shows some evidence for the hypothesis that there is lower employment participation by Q2 households who live in inaccessible locations.

When this dispersal/concentration of different types of jobs/industries is taken into account, it appears that while agglomeration of professional jobs in inner regions of Sydney and Melbourne is important, other types of jobs/industries have a moderate or high degree of dispersal. The research on this point is exploratory, based on statistical aggregates of point-in-time data, and on broad ABS data, but it appears that households are addressing the spatial mismatch between employment and affordable housing opportunities through their housing location decisions. Q2 households in Sydney, and to a lesser extent in Melbourne, appear to be trading off rental affordability to live in locations that provide good access to a range of jobs. This is particularly the case for the middle suburbs which arguably provide the best access to the full range of jobs/industries.

These findings point to several options for further policy development:

- Providing more affordable rental opportunities in locations offering high access to employment would benefit those Q2 households currently living in housing stress, and support the long term sustainability of the labour market. Similarly, it appears that policies to increase affordable supply in middle suburbs may have some impact on employment participation as far as Q2 households are concerned, but the impact on productivity is less clear.

- There may be opportunity to further support spatial dispersal of employment opportunities in Sydney and Melbourne, and to enhance the geography of employment access within Wollongong and Geelong, however, while this may provide more dispersed jobs for some households it may also constitute a drain on productivity, by negating some of the benefits of agglomeration such as transfer of skills to workers. 
- Both strategies would be supported by investments in infrastructure which improves transport accessibility to poorly serviced areas. This means transport options that do not only run in a radial fashion into CBDs of cities but also options to enable access to jobs in clusters around the city and wider metropolitan region. Such strategies would need to be undertaken in tandem with policies to preserve access to affordable rental accommodation for lower income earners, otherwise improved accessibility will be capitalised in market rents and house prices.

The analysis of locational potential for affordable housing development in areas near the key employment concentrations for Q2 workers (Project B) shows that there are few sites where housing could easily be developed that would rent below market levels. Non-market mechanisms may therefore be required to deliver affordable housing in these locations.

These metropolitan planning matters are considered further in the following chapter, which examines existing and potential strategic planning frameworks which fund interventions to better connect employment and affordable housing opportunities, as a key lever for urban productivity growth. 


\section{Strategic planning, place-based funding, and digital innovation}

- Without intervention, the growing shortage of affordable and available rental housing in major cities will continue to push low-income workers into housing stress; endure long journeys to work; or reduce their workforce participation-undermining economic inclusion and, indirectly, urban productivity. This could also contribute to a division between zones of high skill/high paid employment and areas of less skilled, less well paid work. This chapter examines existing and potential strategic planning and funding approaches to address these problems.

- Evidence points to a gap between the objectives of Australian capital city planning frameworks for employment growth and housing affordability and the delivery levers for implementation.

- Internationally, place-based funding interventions such as City Deals have emerged as important models for catalysing new employment and housing development. But measures are needed to ensure that urban investments benefit lower income groups, preserve existing affordability and create new affordable rental housing in accessible locations.

- Satellite cities can also play an important role in providing affordable rental housing for Q2 households and in attracting firms wishing to relocate from higher cost locations. Strategies should support new and skilled employment opportunities within satellite cities, and aim to service new housing areas with high quality public transport options.

- There is considerable interest in the potential for digital and innovation sectors to stimulate new employment opportunities in existing and new locations, including locations where housing costs are lower. However, within Australia, there is a disconnect between policies on innovation and policies on housing, which has serious implications for innovation district development and housing affordability. 
This chapter reviews the existing and potential strategic planning frameworks and interventions to enhance urban productivity by improving connectivity between employment opportunities and affordable rental housing supply. The first section of the chapter reviews existing strategic planning, policy, and funding interventions in Australia. Under Australia's system of government, urban planning and infrastructure provision largely falls within state responsibilities, while detailed land use and development assessment decisions are delegated to local government.

The Australian Government's interest in cities and regions has fluctuated but in recent years there have been a number of national policy interventions regarding urban policy, infrastructure, and strategic funding interventions, such as place-based City Deals. These are considered in the second part of the chapter, which reviews international models for strategic place-based funding interventions and emerging Australian practice.

Lastly, the chapter draws on an analysis of the relationship between access to affordable rental housing and the emergence of new economic and employment opportunities in the digital and innovation economy (Dowling, Maalsen et al. 2020).

\subsection{Australian strategic planning frameworks}

Strategic metropolitan plans set out spatial policies for all of Australia's capital city regions, as summarised in Table 4. These strategies_-prepared by state governments or metropolitan entities such as the Greater Sydney Commission-are implemented through local land use planning instruments which allocate land for business, industry, housing, leisure, and environmental purposes, having regard to transport corridors, existing and planned infrastructure, and environmental or other constraints. In many cases, sub regional plans and or other spatial planning, transport, or infrastructure strategies form part of the wider strategic framework for implementation through local land use controls and decisions.

Research conducted as part of this Inquiry reviewed these overarching metropolitan planning frameworks, focusing on their broad objectives, spatial strategies, and implementation levers (Pill, Gurran et al. 2020: Table 5). All strategies aim to increase jobs and housing in well located areas, with most plans including explicit objectives around jobs and housing connectivity. For instance, the Perth and Peel strategy recognises the spatial mismatch between the central location of the majority of the region's jobs, and the location of existing and planned new housing supply, and aims to address this by better connecting established housing areas with the CBD through public transport and well serviced road networks. The Melbourne and Adelaide plans include specific references to increasing housing supply near existing jobs and public transport, while the Adelaide strategy also recognises opportunities to increase employment near existing housing. 
Table 4: Review of capital city strategic planning frameworks

\begin{tabular}{|c|c|c|c|c|}
\hline & & Jobs/productivity & Housing target & $\begin{array}{l}\text { Affordable housing target } \\
\text { and implementation }\end{array}$ \\
\hline ACT & $\begin{array}{l}\text { ACT Planning Strategy } \\
(2018-2045)\end{array}$ & $\begin{array}{l}\text { Diversify to commercial services } \\
\text { and knowledge-based industries }\end{array}$ & $\begin{array}{l}100,000+\text { over } 25 \text { years; } \\
70 \% \text { in existing areas }\end{array}$ & None \\
\hline NSW & $\begin{array}{l}\text { A Metropolis of Three Cities: } \\
\text { Greater Sydney Regional } \\
\text { Plan (2018) }\end{array}$ & $\begin{array}{l}817,000 \text { jobs; spatially organised } \\
\text { across } 3 \text { 'cities' and sub district } \\
\text { centres }\end{array}$ & $\begin{array}{l}725,000 \text { dwellings } \\
\text { by } 2036\end{array}$ & $\begin{array}{l}5-10 \% \text { of new residential } \\
\text { floorspace (defined } \\
\text { prior to rezoning); to } \\
\text { be implemented when } \\
\text { land rezoned }\end{array}$ \\
\hline NT & $\begin{array}{l}\text { Darwin Regional Land Use } \\
\text { Plan (2015) }\end{array}$ & $\begin{array}{l}\text { Compactness, mixed use } \\
\text { development, and public transport } \\
\text { nodes/high frequency routes }\end{array}$ & $\begin{array}{l}48,000 \text { new dwellings } \\
\text { over } 40-50 \text { years }\end{array}$ & None \\
\hline QLD & $\begin{array}{l}\text { Shaping SEQ: South East } \\
\text { Queensland Regional Plan } \\
\text { (2017) }\end{array}$ & 1 million new jobs & $\begin{array}{l}750,000 \text { over } 25 \text { years; } \\
60 \% \text { in existing areas. }\end{array}$ & None \\
\hline SA & $\begin{array}{l}30 \text { Year Plan for Greater } \\
\text { Adelaide (2010-2040) } \\
\text { (2017-18 Update) }\end{array}$ & $\begin{array}{l}\text { Mixed use activity centres/transit } \\
\text { corridors; infill housing near jobs; } \\
\text { low impact employment near } \\
\text { existing housing }\end{array}$ & $\begin{array}{l}248,000 \text { new dwellings, } \\
85 \% \text { in existing urban } \\
\text { areas }\end{array}$ & $\begin{array}{l}\text { 15\% affordable housing } \\
\text { in all new significant } \\
\text { new development; } \\
\text { implemented when } \\
\text { land rezoned }\end{array}$ \\
\hline TAS & $\begin{array}{l}\text { (Hobart) Capital City Strategy } \\
\text { Plan 2015-2025; Southern } \\
\text { Tasmania Regional Land } \\
\text { Use Strategy 2010-2035 }\end{array}$ & $\begin{array}{l}94,000 \text { jobs; } 92 \% \text { in Greater } \\
\text { Hobart, nearly } 50 \% \text { in Hobart }\end{array}$ & 36,000 new dwellings & None \\
\hline VIC & $\begin{array}{l}\text { Plan Melbourne 2017-2050: } \\
\text { Metropolitan Planning } \\
\text { Strategy (2017) }\end{array}$ & $\begin{array}{l}1.5 \text { million new jobs; funding } \\
\text { for infrastructure support }\end{array}$ & $\begin{array}{l}1.6 \text { million new dwellings. } \\
\text { Policy to deliver more } \\
\text { homes near jobs and } \\
\text { public transport. }\end{array}$ & None \\
\hline WA & $\begin{array}{l}\text { Perth and Peel @ } 3.5 \text { million } \\
\text { 2018-2050 (2018) }\end{array}$ & $\begin{array}{l}\text { Address central jobs/outer housing } \\
\text { mismatch by connecting CBD to } \\
\text { activity centres }\end{array}$ & $\begin{array}{l}880,000 \text { new dwellings; } \\
47 \% \text { infill; } 53 \% \text { greenfield }\end{array}$ & None \\
\hline
\end{tabular}

Source: adapted from Pill, Gurran et al. 2020.

Of the two plans applying to the case study cities which were a focus for this Inquiry, the Greater Sydney Region Plan conceptualises the metropolitan area as three 'cities' with the vision that each will support residents living within 30 minutes of jobs, services, and amenities. Plan Melbourne advances ' 20 minute neighbourhoods' as an organising principle for integrated transport, and aims to increase public transport to the city's outer suburbs. Seven 'national employment innovation clusters' are identified as a focus for jobs growth and strategic infrastructure investment, along with nine 'metropolitan activity centres'. These strategic frameworks aim to establish a strong basis for better aligning the geography of jobs and housing in the nation's largest cities. However, both plans lack concrete and established mechanisms for preserving and delivering affordable rental housing through the development process. 


\subsubsection{Planning frameworks and affordable rental supply}

One of the key levers available to governments seeking to improve housing affordability for lower income renters is to set affordable housing targets alongside wider targets for new housing supply. Targets establish a signal to the market which can be factored into decisions about land acquisition for development or redevelopment, since they are typically implemented through rezoning or master planning processes. Targets also provide an important basis for monitoring progress over time. Targets depend on mechanisms for implementation-for instance, the ability for planning authorities to require affordable housing as a condition of approval (often called 'inclusionary zoning'). Since residential rezoning often occurs alongside major transport and other infrastructure delivery, affordable housing targets and requirements are important measures to ensure that lower income renters remain able to access accommodation in areas benefitting from new infrastructure and growth.

As shown in Table 4, only Sydney and Adelaide specify targets for affordable housing, to be implemented through the rezoning process. The Greater Sydney Region Plan sets an affordable rental housing target of 5-10 per cent of new residential floorspace to provide for Q1 and Q2 households.

In the absence of targets, voluntary incentives such as floor space bonuses or other variations on planning requirements may encourage developers to provide affordable housing. A formal incentive scheme exists under NSW state planning policy, but to date has not resulted in significant output (Gurran, Gilbert et al. 2018). This explains why, despite significant new increases in higher density housing near Sydney and Melbourne's central employment areas, the supply of affordable rental housing has not improved. Targets and deliver mechanisms are therefore needed to secure affordable rental housing in areas already benefitting from good access to jobs as well as in areas undergoing new investment to improve accessibility and catalyse new activity.

\subsubsection{Improving connectivity to employment opportunities, and stimulating growth near areas of existing affordable housing supply}

The delivery of new public transport networks - through bus, light rail or rail services, or all of these-is an important strategy for connecting residential communities to wider employment opportunities. Similarly, improved connectivity may also support new jobs growth in proximity to areas of existing and new housing, such as outer suburban locations where there is demonstrable imbalance between jobs density and housing.

Improving connectivity between satellite cities such as Wollongong or Geelong and central areas of Sydney or Melbourne may also open new employment opportunities for residents of these lower cost housing markets. However, the research evidence collected through the Inquiry emphasised that connectivity within satellite cities to support economic diversification and self containment was a more sustainable strategy than positioning Wollongong and Geelong as 'dormitory' suburbs for Sydney and Melbourne. Further, Wollongong in particular already shows signs of rental pressure likely linked to metropolitan spillover effects, but less so in the case of Geelong (although this may be the case for home ownership rather than rental).

With strategic planning frameworks for both Wollongong and Geelong seeking to stimulate new job creation in accessible areas, there are opportunities to support these ambitions by improving local transport connectivity, and diversifying housing options, particularly in central locations of both cities.

Both Wollongong and Geelong benefit from existing 'anchor' institutions, particularly medical facilities and universities, which provide a strong basis for establishing new knowledge 'clusters'. At the same time, their relatively lower cost housing markets are an incentive for firms and employees to relocate from metropolitan areas to locations with strong lifestyle and amenity benefits.

Across all of the capital and satellite city plans reviewed in this Inquiry, strategies for integrating jobs growth with transport connectivity and housing will depend on both public and private investment for implementation. As discussed further below, strategic place-based deals may provide one model for leveraging this investment. 


\subsection{Strategic place-based funding interventions}

Internationally, place-based metropolitan economic strategies or funding 'deals' between central and local governments around infrastructure investment, urban planning or housing, have sought to address the problems of spatially uneven housing and employment growth. These international models-particularly 'City Deals' in the UK-have been influential in Australia and were reviewed as part of this Inquiry (Pill, Gurran et al. 2020).

\subsubsection{Understanding strategic 'place-based” funding interventions}

International evidence suggests that institutional fragmentation at the metropolitan scale is a drag on productivity growth (Ahrend, Farchy et al. 2014). Place-based deals offer a model for integrating planning and policy co-ordination across different tiers of government and potentially non-governmental agencies and organisations as well. Place-based deals are essentially inter-government contracts, typically between higher (central or state) and lower (state and/ or local/municipality) levels of government, typically addressing issues such as urban or regional development, planning, infrastructure investment, and housing. The potential of deal-making is to bring together separate powers, responsibilities, funds, programs and expertise into a cohesive package which is designed to reflect place-based conditions and priorities.

Research conducted for Project C in this Inquiry reviewed four international models, summarised in Table 5. As shown, these interventions have provided a vehicle for central governments to provide direct funding for infrastructure seen to catalyse local economic development, in return for agreed outcomes to be delivered at the local level.

Table 5: Strategic place-based funding interventions, international models

\begin{tabular}{lll}
\hline Country & Name & Description \\
\hline UK & City Deals & $\begin{array}{l}\text { Multi-layered place-based funding agreements for strategically integrated } \\
\text { infrastructure (including housing), supporting economic development. }\end{array}$ \\
\hline France & Territorial Development Contracts & $\begin{array}{l}\text { Set targets for housing construction and economic development } \\
\text { proximate to new public transit. }\end{array}$ \\
\hline Canada & Urban Development Agreements & $\begin{array}{l}\text { Made across three levels of government to address issues including } \\
\text { affordable housing and economic development. }\end{array}$ \\
\hline US & Community Development Block Grants & $\begin{array}{l}\text { Address housing and place-based disadvantage through local economic } \\
\text { development. }\end{array}$ \\
\hline
\end{tabular}

Source: Pill, Gurran et al. 2020.

The UK experience in developing and implementing City Deals since 2012 was a particular focus for the Inquiry because of its obvious influence on Australian policy making.

\subsubsection{Place-based deals in the UK}

A range of place-based deals have emerged in the UK since the original City Deals commenced in 2012. As summarised in Table 6, there has been a focus on infrastructure funding and integrative governance arrangements in these agreements which tend to be combined on the ground to form a package of funding and commitments. 
Table 6: Place-based deals and strategic funding mechanisms in the UK

\begin{tabular}{ll}
\hline Deal & Key features \\
\hline City Deals & $\begin{array}{l}\text { Original place-based funding agreements between central government, groupings of local } \\
\text { governments, and others, to promote economic growth. }\end{array}$ \\
\hline Growth Deals & $\begin{array}{l}\text { Funding for 'Local Enterprise Partnerships' benefiting local economies. } \\
\text { All cities with City Deals also have Growth Deals. }\end{array}$ \\
\hline Enterprise zones & $\begin{array}{l}\text { Sites within Local Enterprise Partnership areas where businesses receive incentives to start } \\
\text { up or expand. }\end{array}$ \\
\hline Growing Places Fund & $\begin{array}{l}\text { Revolving investment funds (mostly loans) for short-term infrastructure projects and to support } \\
\text { local economic growth. }\end{array}$ \\
\hline Regional Growth Fund & $\begin{array}{l}\text { Funding to encourage private sector enterprise and leverage private sector investment. } \\
\text { Devolution Deals }\end{array}$ \\
$\begin{array}{l}\text { Deals enable local authority and public authority functions to be conferred to combined } \\
\text { authorities. Housing and planning policy are central themes in these deals. }\end{array}$ \\
\hline Housing Infrastructure Fund & $\begin{array}{l}\text { Funding for English local or combined authorities for new infrastructure or to make land } \\
\text { available for housing in high demand areas. }\end{array}$ \\
\hline
\end{tabular}

Source: Adapted from Pill, Gurran et al. 2020.

The importance of affordable housing varies across these agreements (Sandford 2018), however, a number of deals have included a specific focus on supporting residential and affordable residential development.

- The Birmingham City Deal (and related Growth and Devolution Deals) includes redevelopment of public land for housing, finance to support development of affordable homes; central government funding support for a mayoral housing delivery team; and a key worker housing initiative.

- The Manchester City Deal (and Growth and Devolution Deals) includes a £300 million Housing Investment Fund, £50 million for a Land Fund to help local governments prepare brownfield land for housing development, and $£ 8$ million capacity funding to boost support for housing delivery across the region.

- The Newcastle (City Deal) included a joint investment plan with the Homes and Communities Agency (using Newcastle's £25 million Future Homes fund); plus establishment of a housing and land board and mayoral Development Corporation (via the Devolution Deal).

- In Scotland, Edinburgh's City Deal includes £65 million to unlock strategic development sites, a 10-year affordable housing program, and establishment of a regional housing company to provide mid-market homes.

These deals show potential strategies for stimulating wider economic growth and development through housing which is targeted specifically to the needs of low-income earners or in locations of economic disadvantage.

Overall, three primary lessons emerge from the review of international experience that have implications for this Inquiry. First, a focus on infrastructure funding in place-based deals to support economic development has meant that benefits to low-income groups (who are not directly targeted by these interventions) are often unclear. Second, to the extent that housing is considered in place-based deals, the emphasis is often on overall housing supply targets, which have not translated into improved outcomes for low-income households in the private rental market. Indeed, without mechanisms to ensure affordable housing inclusion there is a risk that redevelopment and renewal projects, alongside wider urban investments, will lead to a further pressure on affordability. There is a need to consider the potential impact of transport or other major infrastructure investments on housing markets and the potential displacement of low-income renters when housing markets rise due to improved connectivity.

Third, the primary objectives of funding deals, as well as frameworks for monitoring and measuring performance, need to be made explicit, and governance arrangements should be robust and transparent. Additional capacity funding for local governments to undertake the detailed planning and delivery needed to implement the deals is often required.

We consider further the potential role of place-based funding interventions in the following review of emerging evidence in relation to City Deals in Australia. 


\subsection{Strategic funding interventions in Australia: City Deals in Western Sydney and Geelong}

There is an increasing trend to use place-based funding models in Australia. As noted, the Australian Government has no formal responsibility for urban policy or planning. However, funding agreements have long been a mechanism for the government to influence or support urban and housing outcomes, with the first Commonwealth State Housing Agreements (which provided finance for public housing) tied to the enactment of modern state planning laws and 'slum clearance' projects (Troy 2012). More recently, Australian City Deals have been introduced as partnership agreements between all three levels of government (national, state and local) to foster local economic opportunities and support sustainable growth. Two have been signed in the research case study areas-Western Sydney, and Geelong; while a total of nine deals have commenced or been announced nationwide.

The Western Sydney City Deal (WSCD) was signed in March 2018 by the Australian, NSW and eight local governments (Blue Mountains City, Camden, Campbelltown City, Fairfield City, Hawkesbury City, Liverpool City, Penrith City and Wollondilly Shire Councils).

The deal provides a 20-year framework for coordinating existing and new investment, planning, and infrastructure provision across the Western Parkland City (defined by the Greater Sydney Commission's metropolitan strategy). Its 38 commitments focus on 'a liveable 30-minute city, with infrastructure and facilities that bring residents closer to jobs, services, education and the world' (Department of Infrastructure, Regional Development and Cities 2019: 1). It anticipates 200,000 new jobs, largely stimulated by the Western Sydney Aerotropolis, and a series of initiatives around industry investment, agri-business, science and technology, and higher education.

A key theme is improved connectivity through public transport investment, with the centrepiece being a North South Rail Link; as well as commitments by the NSW Government to establish rapid bus services. 'Planning and housing' are an explicit focus of the deal, which embeds the Greater Sydney Commission 20-year housing supply targets for the Western Sydney District $(184,500)$ and reiterates the State's commitment to ensuring that local councils update their local planning instruments to deliver 6-10-year housing targets. 'Growth Infrastructure Compacts' are to be developed by the NSW Government, to coordinate infrastructure and planning requirements for new development areas. Funding of $\$ 30$ million (\$15 million from the Australian and NSW Governments) forms the Western Parkland City Housing Package, to resource these initiatives.

However, although the deal refers to affordability, there are no specific provisions or initiatives in relation to affordable housing. The WSCD Implementation Plan identifies milestones and performance indicators for the key objectives of the plan. In relation to connectivity, the key performance indicators relate to jobs accessibility within 30 minutes, and work trips by public transport. In relation to 'planning and housing', the performance indicator is simply 'increased housing supply' (Department of Infrastructure, Regional Development and Cities 2018: 8).

The Geelong City Deal was signed in March 2019 by the Australian and Victorian Governments and the City of Greater Geelong. It is a 10-year plan focused on the economic revitalisation of Geelong itself as well as the visitor economy associated with the Great Ocean Road. In total, the Geelong City Deal brings together around \$370 million in investment funds, provided by the Australian, Victorian, and the City of Greater Geelong governments. Key initiatives include a new convention and exhibition centre for Geelong city, a wider central city revitalisation plan, and activation of the Geelong Waterfront. Deakin University's Future Economy Precinct at Waurn Ponds campus will receive funding for expansion, and a new ferry terminal will be constructed at Queenscliff.

\subsubsection{Supporting firms to invest in priority locations or in satellite cities}

All interviewees were positive about the two City Deals. However, NSW informants emphasised the challenges in achieving more integrated land use and infrastructure planning, particularly the upfront provision of infrastructure to service employment lands and residential communities, the promise of additional funding notwithstanding. 
To stimulate employment in suburban and satellite cities, interviewees emphasised the importance of existing 'anchor' (education and medical) institutions-as employers, as educators for the 'new economy' and as providers of opportunity within new knowledge clusters. In Western Sydney these included the planned STEM (Science, Technology, Engineering and Mathematics) 'multiversity' (comprising Western Sydney University, UNSW, and the universities of Wollongong and Newcastle) as part of the Aerotropolis; and the Liverpool Innovation Precinct, anchored by Liverpool Public Hospital, with engagement of three universities and TAFE NSW.

There have been ongoing efforts to attract major employers to Western Sydney, particularly the emerging Aerotropolis. A Memorandum of Understanding (MoU) was signed with major 'foundation' tenants in 2018, and the Investment Attraction Office has been established in Liverpool city centre. The relocation of government offices to Parramatta and Westmead, as well as key firms such as PWC and KPMG, were regarded as important catalysts for Western Sydney.

Interviewees advised that businesses are attracted to Geelong because of the 'affordability factor'. The City of Greater Geelong has benefited from state decentralisation efforts (such as the National Disability Insurance Agency, WorkSafe and the Transport Commission) and recognises Deakin University as a significant anchor.

In terms of connectivity, around 20,000 people from Wollongong and 17,000 people from Geelong commute by train to Sydney/Melbourne respectively, posing challenges in terms of retaining local workforces. Interviews in both case areas pointed to the challenges and paradoxes of seeking better, faster connections whilst attracting and retaining people to not only live but also work in the local area. It is worth noting that the analysis of commuting patterns in Dodson, Li et al. (2020) showed that very few commuters between Wollongong and Sydney or Geelong and Melbourne were Q2 renters. Thus, there will be trade-offs between aspirations for developing diverse and productive local economies in the satellite cities of Wollongong or Geelong versus their existing and potential roles as metropolitan spillover communities serving the high value urban agglomerations of Sydney and Melbourne.

\subsection{Innovation and the digital economy}

There is much interest in the potential for digital and innovation strategies to provide new sources of employment growth, particularly in areas seeking to increase economic activity (Dowling, Maalsen et al. 2020). The innovation sector depends on a diversity of firms and workers, and this diversity depends on access to affordable housing. International evidence suggests that localities offering relative housing affordability, particularly when connected to central markets by transport and ICT infrastructure, are starting to perform well in attracting and fostering new economy jobs, for instance in health-tech, edu-tech, and auto-tech fields (Baily and Montalbano 2018). This suggests that the often under-utilised employment areas in Australia's de-industrialising outer metropolitan and satellite cities might be productively reshaped to support new economy employment in creative, technical, and digital sectors.

\subsubsection{Innovation districts}

Internationally, there have been a number of major initiatives to renew former industrial areas in this way, seeking to generate new economic opportunities through the innovation and digital sectors. Key cases were reviewed in research undertaken for this Inquiry (summarised in Table 7). The nine international innovation districts reviewed incorporate both affordable housing and innovation-led employment strategies, including new mixed use zoning frameworks (permitting residential and compatible semi industrial activity), inclusionary zoning and supporting low-income housing providers with subsidies and/or provision of land.

Innovation districts appear most successful when underpinned by a diversity of firms scaling from startups to established institutions. This mix is however dependent on accessibility to skilled employees and the provision of housing, including affordable and mid-range housing, as well as ICT and transport infrastructure. 
Table 7: Selected international and Australian models of innovation districts

\begin{tabular}{|c|c|c|}
\hline Project & Description & Key features / strategies \\
\hline $\begin{array}{l}\text { Boston Waterfront Innovation } \\
\text { District, } \\
\text { Boston, US }\end{array}$ & Major technology tenants and new startups. & $\begin{array}{l}\text { 'Innovation housing' and 'co-housing', models } \\
\text { developed for low/moderate income workers. }\end{array}$ \\
\hline $\begin{array}{l}\text { Brooklyn Tech Triangle, } \\
\text { US }\end{array}$ & $\begin{array}{l}\text { Rising and established startups such } \\
\text { as Etsy and MakerBot; supported by } \\
\text { 'innovation' zones. }\end{array}$ & $\begin{array}{l}\text { Housing and co-living startups such as Common } \\
\text { and PureHouse disrupting traditional models } \\
\text { of housing provision. }\end{array}$ \\
\hline $\begin{array}{l}\text { Chattanooga Innovation District, } \\
\text { US }\end{array}$ & $\begin{array}{l}\text { First mid-sized US city to implement } \\
\text { an innovation district. Includes diverse } \\
\text { technology startups and corporations. }\end{array}$ & $\begin{array}{l}\text { Affordable housing supported through local tax } \\
\text { breaks for incorporating affordable housing. }\end{array}$ \\
\hline $\begin{array}{l}\text { 22@ project, } \\
\text { Barcelona, Spain }\end{array}$ & $\begin{array}{l}\text { Large urban renewal schemes, commencing } \\
\text { in } 2000 \text { on former industrial land. New tech/ } \\
\text { innovation district to incorporate subsidized } \\
\text { housing, amenities and green areas. }\end{array}$ & $\begin{array}{l}\text { Land owners required to cede up to } 30 \% \\
\text { of their land to deliver subsidised housing, } \\
\text { amenities, and green space. }\end{array}$ \\
\hline $\begin{array}{l}\text { Kings Cross Innovation District, } \\
\text { UK }\end{array}$ & $\begin{array}{l}\text { Major mixed use regeneration project } \\
\text { in close proximity to anchor institutions } \\
\text { including universities, British Library and } \\
\text { St Pancras Hospital. }\end{array}$ & $\begin{array}{l}2,000 \text { new homes for mixed income groups, } \\
22 \% \text { of which were affordable and social } \\
\text { housing units, including specific projects } \\
\text { for key workers and students, and share/ } \\
\text { affordable home ownership options. }\end{array}$ \\
\hline $\begin{array}{l}\text { Tonsley Innovation District, } \\
\text { Adelaide, AUS }\end{array}$ & $\begin{array}{l}\text { Australia's first innovation district, provides } \\
\text { both commercial and residential spaces. }\end{array}$ & $\begin{array}{l}\text { An affordable and 'connected' residential } \\
\text { community; subject to South Australia's } \\
15 \% \text { inclusionary housing requirement. }\end{array}$ \\
\hline $\begin{array}{l}\text { Hunter Innovation Project, } \\
\text { Newcastle, AUS }\end{array}$ & $\begin{array}{l}\text { Includes smart infrastructure, physical } \\
\text { spaces for incubation and innovation, } \\
\text { and a high profile digital precinct. }\end{array}$ & $\begin{array}{l}\text { Part of Newcastle City Council's Smart } \\
\text { City strategy, aims to attract and retain } \\
\text { entrepreneurs and knowledge workers. }\end{array}$ \\
\hline $\begin{array}{l}\text { Byron Arts and Industrial } \\
\text { Precinct, AUS }\end{array}$ & $\begin{array}{l}\text { Emerging live/work precinct engaging a } \\
\text { combination of local firms and startups } \\
\text { across IT, creative manufacture, food, } \\
\text { and arts industries. }\end{array}$ & $\begin{array}{l}\text { Within former 'traditional' industrial/bulky } \\
\text { goods zone. Well designed lower cost home } \\
\text { ownership/rental products, connected to town } \\
\text { centre via cycle and pedestrian networks. } \\
\text { Online marketing/proximity to Brisbane } \\
\text { supports new firms to relocate/establish in } \\
\text { lower cost northern rivers region. }\end{array}$ \\
\hline
\end{tabular}

Source: Adapted from Dowling, Maalsen et al. 2020.

There is strong potential for new live/work models to emerge in Australia. Examples of successful live/work housing typologies have been demonstrated in precincts such as the Byron Arts and Industrial Precinct (Northern NSW) and the Tonsley Innovation District in Adelaide (Table 7), showcasing opportunities for mixed use development underpinned by skilled knowledge, creative, and technology firms and diverse housing options. Unlike traditional forms of industry and manufacturing which are often incompatible with residential development, innovation sector firms often have low offsite impacts to surrounding land uses. In fact, the potential for better integrating work and residential life can represent an important attraction for these firms and their employees.

Both the international and Australian examples show that, alongside high quality infrastructure and natural/cultural amenities, diverse and affordable housing is key to attracting and retaining knowledge workers in new innovation districts. Further, the international experience demonstrates the risks to housing affordability as innovation areas become successful. The South Australian model of requiring affordable housing in new development has helped ensure that housing units in the Tonsley Innovation District include affordable options to rent and purchase. By contrast, in the absence of such requirements the housing produced in the Byron Arts and Industrial Precinct is not affordable to much of the target workforce (creative workers who typically earn lower or unpredictable incomes). 


\subsubsection{Innovation economies and affordable rental housing: the perspectives of firms}

The success of innovation-led employment policies is dependent on their ability to reflect and shape the actions of firms. Thus, this element of the Inquiry considered the perspectives of firms, and in particular the perspectives of small firms described as 'startups'. This sector is critical to the functioning and growth of an innovation precinct, and growing rapidly in Australia. In 2018 there were an estimated 1,500 startups in Australia, almost double that of 2015 (Startup Muster 2018: 5). The sector is characterised by high turnover and a young workforce; around 40 per cent of startup founders are below 40 years of age. Working from home or in a co-working space is common. Firms interviewed as part of research for this Inquiry advised that access to professional networks (often located in Sydney and Melbourne's inner city areas) was critical in the startup phases of their business.

For firms in the digital innovation and startup sectors of outer Western Sydney, Wollongong and Geelong, access to a large pool of skilled labour was seen to be important, including the opportunity to attract locally based knowledge workers currently commuting to the CBDs of Sydney and Melbourne.

Lifestyle and amenity were also crucial for attracting knowledge industry businesses not dependent on central city locations. However, interviewees advised that smaller, satellite city firms were unable to offer central city wages, and that this wage differential was not fully offset by lower rents. Nevertheless, some interviewees advised that if skilled workers exit central city areas (for instance, in search of more affordable accommodation, often in high amenity/lower cost areas), firms are likely to follow. In other words, a chain process might precipitate firm relocations indirectly related to the availability of affordable accommodation, but this would also depend on digital and physical connections (freight and passenger transport), appropriate employment and residential opportunities, and amenity (environmental and cultural attractions).

These findings suggest that well located affordable rental housing is an important factor, among others, for young entrepreneurs to engage successfully in the startup and digital economy. The pervasive lack of affordable rental housing has meant that many younger entrepreneurs rely on a second job, remain living in the parental home, or live in lower rent share homes to sustain their ventures. These compromises were seen to have constrained their potential productivity and emerging businesses, and are likely to be unsustainable in the long term.

\subsection{Summary and implications for policy development}

This section of the report has considered existing and potential strategic policy and funding interventions for improving urban productivity by addressing spatial mismatches between housing and employment opportunities. There is evidence of strong strategic policy support for reducing housing and commuting burdens of low-income earners by better connecting home and work locations via the idea of the ' 30 minute city' in Australia's Smart City Plan, and reinforced by capital city strategic planning frameworks. However, the mechanisms for delivering these goals, and particularly for preserving and creating well located affordable rental housing at the scale required, remain largely absent.

There is growing interest in the potential for innovation districts to catalyse new economic opportunities, particularly in locations where additional employment is needed. The evidence developed through this Inquiry shows the critical importance of locational advantages-including existing anchor institutions and knowledge clusters; proximity to natural and cultural amenities; and infrastructure enabling digital and physical connectivity-to the establishment of innovation districts. These locational advantages can be supported through land use planning frameworks which enable live/work precincts, and through place-based funding to support digital and physical connectivity beyond central city areas.

Internationally, affordable and diverse housing is often integral to successful innovation districts. However, within Australia, there is a strong disconnect between policies on innovation and policies on housing. 
Internationally, and increasingly in Australia, strategic place-based funding interventions, such as City Deals offer a mechanism for catalysing economic and housing growth through targeted investment in infrastructure, including infrastructure to support the emergence of the technology and innovation sectors. However, in contexts where new infrastructure or other investment may inflate local house prices or rents, it is critical to ensure that existing affordable rental housing supply is preserved, and new opportunities created.

Further caveats apply in relation to the potential for digital innovation strategies to support Q2 households. It is not clear what income quintile is likely to be employed in innovation districts. If these places attract higher quintile workers who also capture the co-located affordable housing then there is little benefit for workers in Q2 households. If this cohort is a concern for policy, then targeted affordable housing interventions need to be designed that are not necessarily available to higher income groups. The City Deal framework—in which funding is leveraged on the basis of negotiated agreements - provides an opportunity to ensure than affordable housing provisions are supported and enabled by state and local governments receiving Australian Government resources. 


\section{Policy development options}

- This final chapter summarises key findings and potential policy responses identified through this Inquiry.

- Three primary policy development options are outlined-increasing affordable rental housing near key employment areas; improving accessibility and connectivity to outer suburban and satellite city housing markets through strategic investment in transport and communications infrastructure; and 'concentrated decentralisation'-fostering new employment clusters through strategic place-based funding interventions and digital innovation.

- Providing more affordable rental opportunities in locations offering high access to employment would benefit Q2 households currently living in housing stress and support long term labour market sustainability. In particular, policies to increase affordable supply in middle suburbs through new development incorporating lower cost rental housing would assist employment participation by Q2 households and reduce rental affordability stress.

- Place-based funding interventions such as City Deals have emerged as important models for catalysing new development, including housing, through strategic investment. Growing use of these models in Australian cities represents an opportunity to link transport and infrastructure investment to affordable housing in accessible locations.

- Digital and innovation sectors can play an important role in urban productivity by supporting new work practices such as telecommuting, and potentially by creating new economic opportunities in locations where housing costs are lower, such as the outer suburbs of major cities and in satellite or regional cities. Planned innovation precincts which cluster around 'anchor institutions' like universities can achieve agglomeration benefits, particularly if supported by high quality transport and communications infrastructure. However, mechanisms to preserve affordability and ensure that new affordable rental housing is created as part of new development are important. 
This Inquiry has examined relationships between affordable rental housing and urban productivity, focusing particularly on the location and availability (shortage/surplus) of affordable rental housing relative to employment and labour market indicators in capital cities and satellite cities. The empirical research collected to inform the Inquiry provides strong evidence of what appears to be structural rather than cyclical change in the Australian housing system (Hulse, Reynolds et al. 2019). In particular, the PRS has been growing since 2001 at twice the rate of all households and at an accelerating rate in the decade from 2006 to 2016.

Current policy settings-including capital city planning frameworks which have emphasised ambitious new housing targets - appear to have facilitated this increase in aggregate supply. However, barriers to first home ownership, particularly in the capital cities, have contributed to important structural changes in the private rental sector, namely:

1. an increase in dwellings with mid-market rents, and

2. an increase in PRS households at mid-higher income levels.

At the same time, reduced availability of social housing for very low-income earners, and increased demand for rental housing by Q3 moderate income earners, means that Q2 income households are increasingly facing affordability burdens in finding housing accessible to central city employment opportunities (Hulse, Reynolds et al 2019: 31, 36). The policy challenge is to develop enhanced settings that can elicit a greater supply of lower rent housing in locations accessible to employment opportunities, and this challenge has become increasingly urgent in view of the Inquiry findings.

This final chapter summarises the key findings and policy implications arising from the Inquiry, and presents potential options for policy development.

\subsection{Summary of key findings}

In summary, empirical findings from the four research projects in this Inquiry show that there has been tremendous growth in the PRS under Australia's housing policy settings in the two decades from 1996. This expansion of the PRS is part of the notable levels of new and typically higher density housing supply facilitated by capital city planning policies designed to increase housing near transport and employment centres. However, overall these policies have not led to an increase in the supply of private rental dwellings affordable to those on lower incomes.

Continuing and intensifying a trend observed 2006-11, the shortage of affordable and available private rentals for Q2 households increased from 2011-16 (Hulse, Reynolds et al. 2019). Most acute in metropolitan regions, particularly Sydney, the shortage has resulted in deteriorating affordability outcomes for Q2 metropolitan private renter households. Similar shortages are starting to emerge in satellite cities as well.

These findings have potentially serious implications for urban productivity. Low-income (Q2) renters who are strongly engaged in the labour market are faced with trading off housing affordability for access to employment opportunities. Q2 renter households and workers who do not live in inner areas tend to be at the lower end of the Q2 income scale, and are likely to endure high commuting burdens.

There is an ongoing opportunity to increase housing within inner ring and middle ring areas to provide affordable housing in areas with a higher density of industries and occupations. As outlined, both Melbourne and Sydney offer significant capacity for increased housing supply even under current planning rules. The findings of this study suggest however, that in many locations, market barriers (rather than planning constraints) are preventing take up of these opportunities. The market is choosing to supply housing at lower densities than planning regulation allows, which suggests that planning system interventions seeking to stimulate new supply by further 'upzoning' residential areas are not the most efficient solution. Additional interventions are needed to encourage the market to use spare capacity under existing planning schemes to deliver new and affordable housing in these locations. 
Our review of strategic policy interventions and funding deals used internationally, and increasingly in Australia, suggests that these collaborative place-based interventions can catalyse new growth through transformative infrastructure or other investment, but specific strategies are needed to ensure that affordable housing is created and preserved.

Finally, this Inquiry has provided 'first cut' evidence on the role of affordable rental housing in the context of smart cities, with the potential for digital innovation and technology industries to support economic growth in suburban and regional areas increasingly recognised in Australia.

The findings suggest firstly that access to secure and affordable housing is an important precondition for digital startups; and secondly, that strategies to foster innovation firms may be effective in high amenity satellite cities where existing skilled workers already reside and others may be attracted to relocate. However, strategies for fostering digital innovation industry precincts accessible to existing and future affordable rental housing supply are undeveloped.

\subsection{Potential policy development options}

Drawing on these findings, the following policy development options emerge (summarised in Table 8).

\subsubsection{Increasing affordable rental housing near key employment areas}

This strategy recognises that central city areas will continue to attract and absorb higher value, productive sectors of employment and wider jobs growth. It is essential that all three levels of government mobilise more policy levers and resources to increase new affordable rental housing supply in these central areas.

Key strategies include using well located government land for affordable rental housing development, and requiring affordable homes to be included as part of all residential projects. Again, the City Deal framework provides a model for investing in catalytic infrastructure, which may include a direct investment in affordable housing, while leveraging local responses. These local responses might also include land dedication as well as planning requirements for affordable rental housing in major new developments.

These requirements should be 'matched to market' so could include mechanisms to maintain affordable home ownership for lower and moderate income earners (such as the South Australian model); or to ensure that a proportion of new dwellings are available to lower income households at an affordable rent. In most parts of Australia, state governments will need to adjust their land use planning frameworks to enable local authorities to implement their own affordable housing schemes.

In addition to mandatory affordable housing requirements in areas benefitting from public investment and major 'upzoning' for residential development, density bonuses offer an additional mechanism to secure affordable housing accessible to established employment centres. Density bonuses provide an opportunity to encourage projects in well located areas to include affordable rental housing in exchange for increased development potential, as occurs in Sydney, where developers can achieve additional floorspace in return for ensuring that a proportion of dwelling units are rented to eligible households at a 20 per cent market discount for at least 10 years. However, density bonuses might only be appropriate where current levels of residential development in the local residential zones are approaching a given threshold relative to the maximum currently permitted in that zone, such as the $90^{\text {th }}$ percentile.

Overall, strong governance frameworks for engaging Australian Government, state, and local partners, as well as key private and non profit agencies, are critical to achieving economic and social outcomes. 


\subsubsection{Targeting locations for new affordable rental housing supply}

Two of the projects for this Inquiry considered opportunities to improve the supply of affordable rental housing in Sydney and Melbourne in targeted locations with good access to employment opportunities. Project B sought to identify suitable locations for new affordable housing supply, having regard to improved job proximity; lower rental costs; and capacity for new housing relative to existing zoning controls. The analysis of potential capacity for increased housing supply focused on the 'gap' between existing residential density and permissible density under the relevant planning regulation.

This analysis showed considerable development potential (i.e. potential for increased new housing supply) under existing planning controls, suggesting that lower densities in these areas are likely to reflect market rather than regulatory barriers. For instance, it was revealed that increased development of residential areas in Melbourne up to the $75^{\text {th }}$ percentile level of total permitted density ( $17.3 \mathrm{dwellings}$ per hectare), would accommodate an extra 245,983 dwellings without changing land-use zoning. This figure rises to 660,469 if residential zones were developed to the current $90^{\text {th }}$ percentile density of 29.9 dwellings per hectare, a number equivalent to one third of the total dwelling count in the greater Melbourne area (Dodson, Li et al. 2020: 45).

In Sydney there is greater utilisation of potential development capacity (75.8 dwellings per hectare at the $90^{\text {th }}$ percentile). However, the analysis found that an additional 167,942 dwellings could be accommodated in Sydney within current residential zonings if this capacity were taken up, representing around 9 per cent of the current Sydney dwelling stock and around a fifth of the city's planned new supply. When the affordability criteria (lower rents) was applied, the potential locations for rental housing which also offered accessibility to employment centres was significantly reduced, although the authors noted that subsidy (and or development by a non profit housing provider) could overcome this market criteria (Dodson, Li et al. 2020: 45).

Similarly, analysis undertaken in Project C identified locations where rents were marginally unaffordable for Q2 workers, as areas where targeted intervention could be effective in securing new affordable rental supply via modest subsidy or through planning requirements (i.e. to maintain affordable rents for a proportion of new units within residential developments). In NSW, state interventions to operationalise the inclusionary zoning mechanism in these locations may increase affordable rental housing without imposing significant cost to developers, government or other purchasers, particularly if introduced alongside other investments to catalyse new housing development. 
Figure 17: Employment density and potential affordable rental housing supply, Sydney

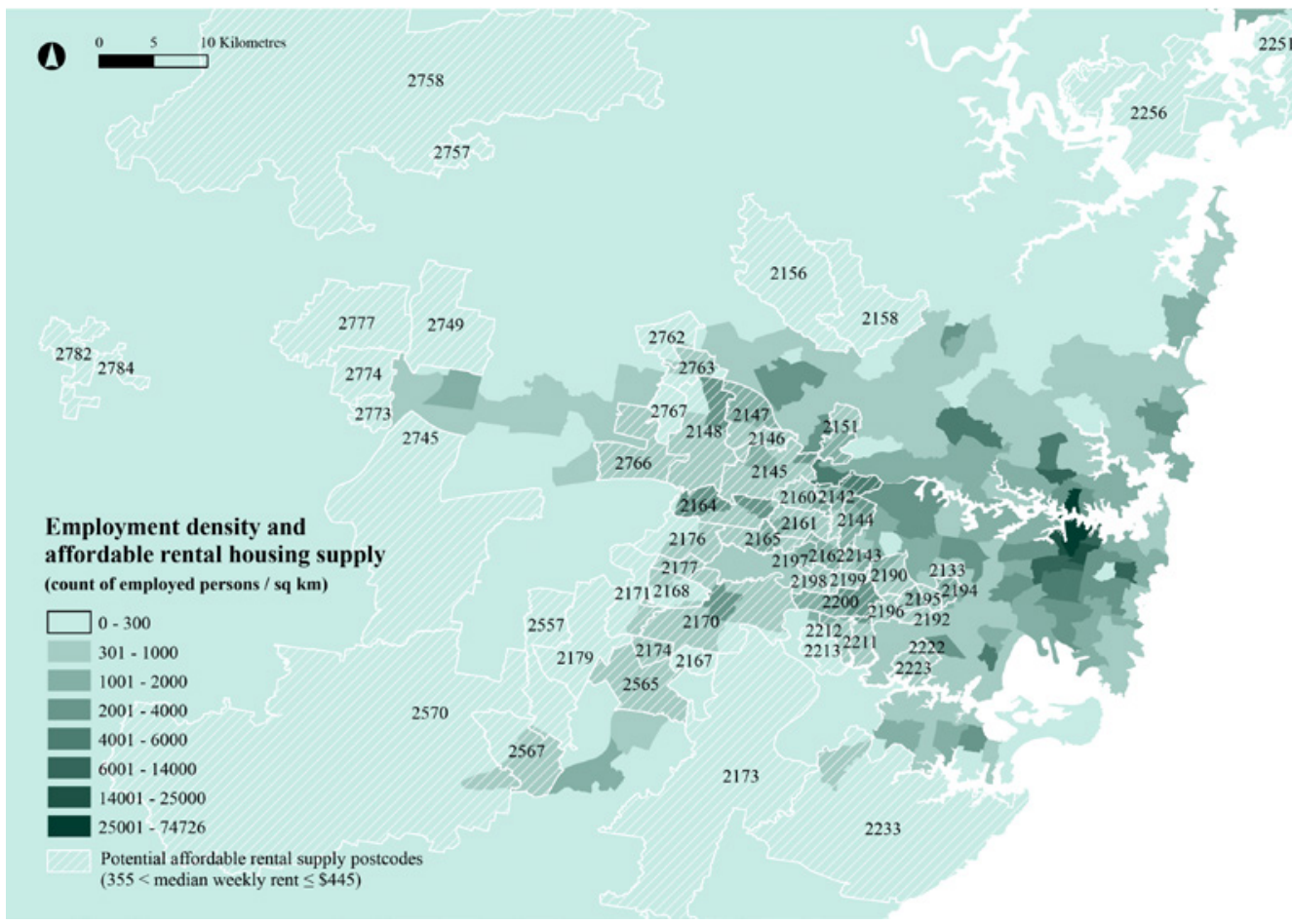

Source: Adapted from Pill, Gurran et al. (2020) and drawing on Fair Trading, NSW Government, 2016; ABS Census 2016 TableBuilder - Counting Employed Persons, at Place of Work (employment); OpenStreetMap (train and light rail line).

Figure 18: Employment density and potential affordable rental supply, Melbourne

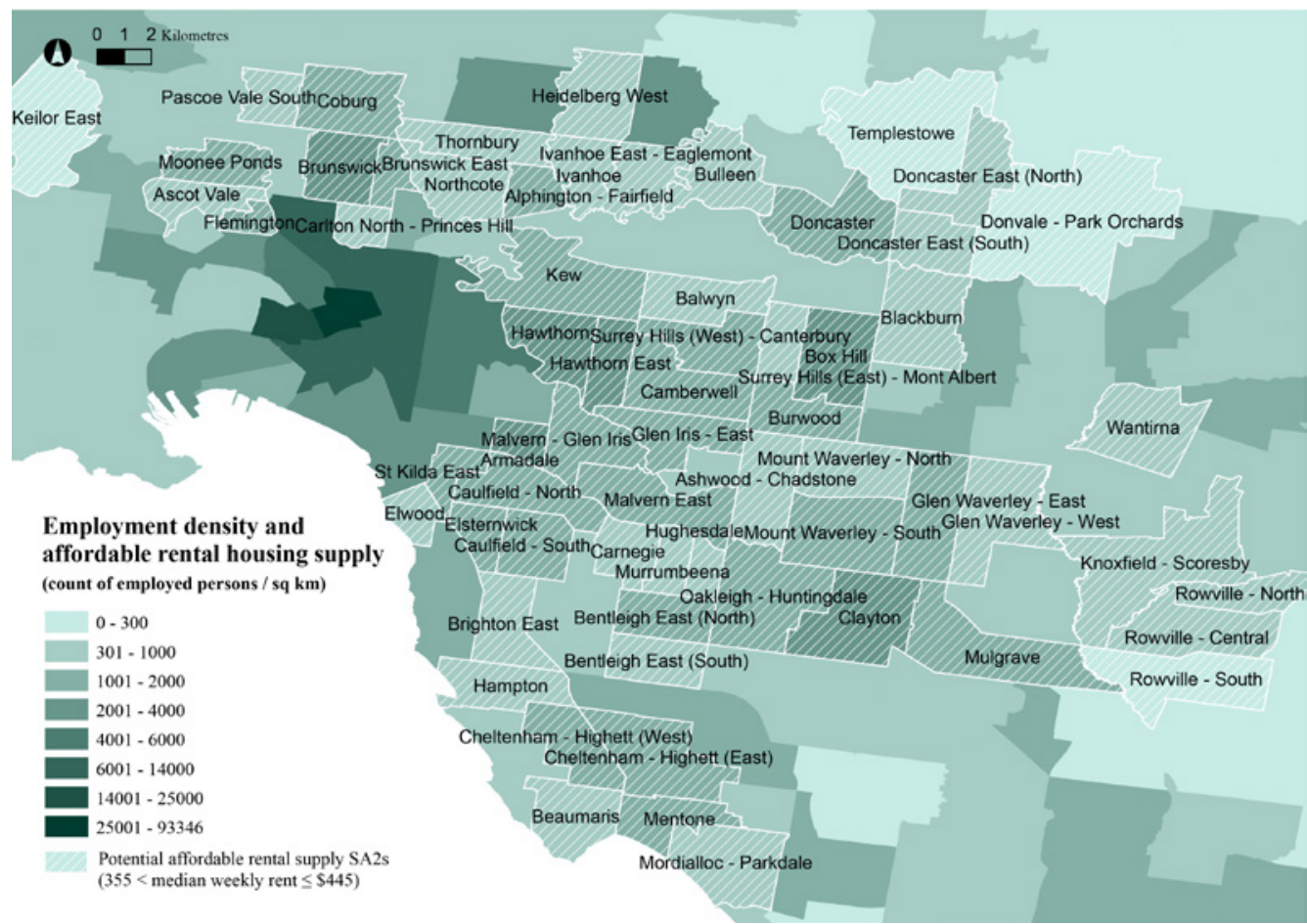

Source: Adapted from Pill, Gurran et al. (2020) and drawing on Rental Reports, Victoria State Government, 2016; ABS Census 2016 TableBuilder - Counting Employed Persons, at Place of Work; OpenStreetMap (train and light rail line). 


\subsection{3 'Concentrated' decentralised employment opportunities, by leveraging strategic place-based funding interventions and digital innovation}

The objective of this approach is to increase accessibility to employment opportunities, including skilled employment, in locations that are undersupplied by jobs. In these areas, housing markets are typically more affordable and the research presented in this Inquiry shows that some lower income households living in these areas are also more likely to have the type of jobs which are more dispersed. Overall however, more affordable housing markets are also those with poor accessibility to employment opportunity, meaning that low-income earners may need to accept lower workforce participation, or endure a long commute to work.

Our review of strategic policy interventions and funding 'deals' used internationally, and increasingly in Australia, suggests that these 'bespoke' models can catalyse new economic opportunities in targeted locations, often through infrastructure and transport upgrades. However, explicit levers to preserve and create affordable housing are needed to ensure that Q2 renters are able to access accommodation in higher value capital city markets, such as Western Sydney.

Such deals could provide funding for infrastructure and related urban initiatives in return for strong commitment to local strategic planning interventions, for instance, the development of mixed use and live/work employment sub-metropolitan centres compatible with the needs of innovation industries, including Q2 workers to service these centres.

New innovation entrepreneurs are supported in establishing and expanding startups by lower housing costs, suggesting that live/work innovation precincts and development models might enable new knowledge sector firms in high amenity satellite city locations. Policy initiatives linking housing and smart city initiatives are not yet embedded in Australian metropolitan planning, however models emerging in Newcastle, Adelaide, and Northern NSW provide a starting point for emulation and adaptation.

Land use planning frameworks may support the development of innovation precincts, through models such as 'live/work' zones; while strategic place-based funding interventions could prioritise connectivity (physical and digital) to enable new firms to operate outside established central city areas; as well as amenity qualities (local cycle/pedestrian networks, distinctive and sustainable urban design) to attract digital entrepreneurs and their staff. Digital connectivity would also enhance opportunities for working from home, heightened by the COVID-19 pandemic. Both state and local governments have a role to play in leading and delivering these outcomes.

\subsubsection{Improving the accessibility of outer suburban and satellite city housing markets}

This closely related approach aims to better connect locations of existing jobs and housing, through strategic investment in transport infrastructure.

Again, place-based funding interventions are an ideal vehicle to deliver transformative infrastructure investments such as rail and bus networks or transit corridors, and to leverage commensurate commitments from local governments. Core requirements may include the need for affordable housing provisions in areas benefitting from the investment, to preserve affordability and ensure that new development catalysed by improved transport accessibility will contribute to affordable rental supply.

Value capture-a levy on development or property which directly benefits from the investment, provides one model for governments to recoup costs of infrastructure provision. The value capture revenue stream can help finance the project or support additional affordable housing provision.

There is some evidence of housing market driven decentralisation, particularly from Sydney, to satellite areas such as Wollongong and the Central Coast. Strategies to support this process include investment to deliver transport and digital connectivity, enabling firms to establish in these locations, which already accommodate skilled workers, and may attract more workers for high amenity and lower housing costs, particularly in the post COVID-19 context. 
However, it is unlikely that growth in satellite cities will substantively impact on Sydney and Melbourne's rental housing markets, at least in the short to medium term, given the disparities of scale. Thus state and local action to develop new strategies for increasing the supply of rental housing affordable and available to Q2 households, in accessible locations, remains critical, particularly in well-located middle suburbs. This would include planning at a precinct level to achieve supply affordable to lower income workers, as well as meeting a range of other objectives, such as improving accessibility to green space and environmental sustainability measures including nature-based solutions. However in order to ensure that new supply affordable to lower income renter households is not captured by middle/higher income households some further mechanism will be needed, such as an affordable housing agency that operates income-based rental policies.

Table 8 summarises potential policy interventions to improve economic inclusion and urban productivity by increasing the supply of affordable rental housing near key employment areas; making outer suburban and satellite city housing markets more accessible to employment opportunities; and fostering new jobs in strategic locations near existing and potential affordable rental supply. These options are broad scale and are most likely to have impact when combined as a suite of measures, rather than used in isolation.

Table 8: Summary of potential policy options and interventions

\begin{tabular}{|c|c|c|}
\hline Strategy & Potential policy option / intervention & Opportunities / limitations \\
\hline $\begin{array}{l}\text { - Concentrated decentralisation } \\
\text {-fostering new employment } \\
\text { opportunities in strategic and } \\
\text { accessible locations around } \\
\text { major transport/ infrastructure } \\
\text { investments }\end{array}$ & $\begin{array}{l}\text { - Place-based deals which fund } \\
\text { transformative infrastructure } \\
\text { investments, and integrate planning/ } \\
\text { delivery to realise employment and } \\
\text { housing opportunities } \\
\text { - Mixed use and live/work } \\
\text { employment precincts } \\
\text { - Improved transport networks to } \\
\text { ensure greater overall metropolitan } \\
\text { labour market accessibility }\end{array}$ & $\begin{array}{l}\text { - Complexity of governance frameworks } \\
\text { - Risks associated with new development models } \\
\text { - Need mechanisms to preserve/ create } \\
\text { affordable rental housing in areas of new } \\
\text { development and investment }\end{array}$ \\
\hline $\begin{array}{l}\text { - Improving the accessibility of } \\
\text { outer suburban and satellite } \\
\text { city housing markets }\end{array}$ & $\begin{array}{l}\text { - Place-based deals to strategically } \\
\text { plan around transformative } \\
\text { infrastructure investment } \\
\text { - New public transport provision-rail } \\
\text { and bus networks, transit corridors } \\
\text { - Value capture mechanisms in } \\
\text { areas benefitting from transport } \\
\text { investment }\end{array}$ & $\begin{array}{l}\text { - Need to preserve affordability in areas } \\
\text { experiencing value uplift associated with } \\
\text { new infrastructure, through inclusionary } \\
\text { planning requirements and rental protections } \\
\text { - Competition for value capture revenue stream }\end{array}$ \\
\hline $\begin{array}{l}\text { - Increasing affordable rental } \\
\text { housing near key employment } \\
\text { areas } \\
\text { - Targeting locations for affordable } \\
\text { rental housing supply }\end{array}$ & $\begin{array}{l}\text { - Inclusionary planning requirements } \\
\text { (ensuring that new affordable rental } \\
\text { supply is targeted towards lower } \\
\text { income Q2 households) } \\
\text { - Build to rent projects } \\
\text { - Use of well located government } \\
\text { land for affordable rental housing } \\
\text { development }\end{array}$ & $\begin{array}{l}\text { - Being developed in Sydney, Melbourne, but } \\
\text { not systematically used/available, nor likely } \\
\text { to deliver at scale required } \\
\text { - Will need to incorporate dedicated units } \\
\text { affordable to local Q2 workers } \\
\text { - Not clear whether build to rent will have any } \\
\text { effect on affordable rental supply but will meet } \\
\text { a market need at mid market for convenient } \\
\text { housing with facilities/amenities on-site and } \\
\text { long term tenure security }\end{array}$ \\
\hline
\end{tabular}

Source: Authors.

It is important to consider these interventions in the context of economic and housing market contexts and cycles. With private sector led new housing construction likely to be subdued in the intermediate and perhaps medium term following COVID-19, mechanisms such as inclusionary zoning alone will have limited impact on the supply of affordable rental units. By contrast, strategic infrastructure projects will contribute to long term urban connectivity, increasing housing and employment opportunities, including for lower income earners. Inclusionary planning requirements can ensure that affordable rental opportunities are embedded in new residential development stimulated by such government investment vehicles. 


\subsection{Limitations of the Inquiry and priorities for further research}

The findings of this Inquiry raise policy tensions in economic and spatial planning. As noted, urban agglomeration is widely understood as generating productivity gains from shared infrastructure, deep labour pools and knowledge spillovers. There is evidence from the research undertaken in this Inquiry that in some locations the intense concentration of employment in city centres is enabling productivity, yet also spurring house price inflation through increasing demand and land values in proximate locations with high accessibility to employment centres.

As outlined in this report, this process has implications for lower income households such as Q2s, who are pushed out by rising rents to less job-accessible locations, or experience housing stress. A research priority is to investigate further the housing affordability/travel/employment trade-offs being made by Q2 renter households in Australia's cities and regions.

More widely, we lack clear evidence in Australia of the relative productivity benefits and costs of intense urban economic agglomeration, and whether the benefits of agglomeration can be achieved at smaller scales, through targeted dispersion. This Inquiry was not able to explore this possibility, but examining the outcomes of recent metropolitan planning efforts to foster smaller, connected urban agglomerations in Australia, each with their own internal labour market and housing market dynamics, is a second research priority. As place-based funding interventions-Australia's City Deals-are implemented, their efficacy in stimulating economic growth in new locations should be closely evaluated, alongside wider social and environmental objectives, including affordable housing outcomes.

Lastly, the potential for digital innovation to transform work practices, and for the digital sector to support economic opportunity in new locations, deserves ongoing research attention. As evidenced in this Inquiry, strategic efforts to support these opportunities remain nascent. There is significant potential to link 'smart city' and digital innovation strategies more closely to spatial and housing policies, and efforts to do so should be carefully monitored.

These research priorities have become more pressing in the light of the COVID-19 Pandemic.

\subsection{Final remarks}

The wider context for this Inquiry has been rising national debate about the impacts of population growth, which has primarily concentrated in Australia's major cities. This growth has been driven by international and internal migration to Australia's major employment centres. This central city concentration of economic and population growth aligns with an understanding that agglomeration, particularly for high skills industries and occupations, supports increased productivity.

At the same time there has been growing interest in the potential to foster new opportunities beyond existing employment centres, as a strategy to reduce perceived spatial inequalities, ease urban congestion, and reduce housing market pressures. The COVID-19 experience internationally may also call into question the public health risks of agglomeration, which can have dire effects on urban productivity, at least in the short to medium term.

Opportunities presented in the digital and innovation economy may support more balanced and inclusive models of urban and regional development by providing greater flexibility in the locations of work and home. The recent and sudden transition of large sectors of the workforce to remote and work-from-home arrangements during the COVID-19 pandemic suggest new alternatives to established models of urban agglomeration may emerge in the near future.

However, these opportunities are likely to support higher income and higher skills workers in the knowledge economy, with private rental sector affordability remaining critical to less skilled workers in lower income households under existing and potential new urban and regional geographies. 


\section{References}

Australian Bureau of Statistics (ABS) 2019, Survey of Income and Housing 2017-18, cat. no. 6553.0, ABS, Canberra.

Ahrend, R., Farchy, E., Kaplanis, I. and Lembcke, A. (2014) 'What makes cities more productive? Evidence on the role of urban governance from five OECD countries', Journal of Regional Science, vol. 56, no. 3: 385-410, doi: $10.1111 /$ jors.12334.

Baily, M. N. and Montalbano, N. (2018) Clusters and Innovation Districts: Lessons from the United States Experience, Brookings Institution, Washington DC.

Been, V., Ellen, I. G. and O’Regan, K. (2019) 'Supply skepticism: housing supply and affordability', Housing Policy Debate, vol. 29, no. 1: 25-40, doi: 10.1080/10511482.2018.1476899.

Beer, A. (2018) 'The closure of the Australian car manufacturing industry: redundancy, policy and community impacts', Australian Geographer, vol. 49, no. 3: 419-438.

Beswick, J., Alexandri, G., Byrne, M., Vives-Miró, S., Fields, D., Hodkinson, S. and Janoschka, M. (2016) 'Speculating on London's housing future: the rise of global corporate landlords in 'post-crisis' urban landscapes', City, vol. 20, no. 2: 321-341, doi: 10.1080/13604813.2016.1145946.

Bone, J. (2014) 'Neoliberal nomads: housing insecurity and the revival of private renting in the UK', Sociological Research Online, vol. 19, no. 4: 1-14, doi: 10.5153/sro.3491.

Byrne, M. (2020) 'Generation rent and the financialization of housing: a comparative exploration of the growth of the private rental sector in Ireland, the UK and Spain', Housing Studies, vol. 35, no. 4: 743-765, doi: 10.1080/02673037. 2019.1632813

Carliner, M. and Marya, E. (2016) Rental housing: an international comparison, working paper, Harvard Joint Center for Housing Studies, Harvard, MA.

Cassidy, N. and Parsons, S. (2017) The rising share of part-time employment, RBA Bulletin, Reserve Bank of Australia, Sydney, https://www.rba.gov.au/publications/bulletin/2017/sep/pdf/bu-0917-3-the-rising-share-of-part-timeemployment.pdf.

Cervero, R. (1989) 'Jobs-housing balancing and regional mobility', Journal of the American Planning Association, vol. 55, no. 2: 136-150, doi:10.1080/01944368908976014.

Ciccone, A. and Hall, R. E. (1993) Productivity and the Density of Economic Activity, National Bureau of Economic Research, Cambridge, MA, https://www.nber.org/papers/w4313.

COAG Reform Council (2011) Review of Capital City Strategic Planning Systems: Report to the Council of Australian Governments, COAG Reform Council, Sydney.

Crook, T. and Kemp, P. (eds) (2014) Private rental housing: comparative perspectives, Edward Elgar Publishing, Cheltenham, UK.

Department of Infrastructure and Regional Development (DIRD) (2015) State of Australian Cities 2014-2015, Australian Government, Canberra, https://www.infrastructure.gov.au/infrastructure/pab/soac/index.aspx.

Department of Infrastructure, Regional Development and Cities (2018) Western Sydney City Deal - Implementation, Australian Government, Canberra, https://www.infrastructure.gov.au/cities/city-deals/western-sydney/files/ western-sydney-city-deal-implementation-plan.pdf. 
Department of Infrastructure, Regional Development and Cities (2019) National Cities Performance Framework Dashboard, Australian Government, Canberra, https://www.bitre.gov.au/national-cities-performance-framework.

Department of the Prime Minister and Cabinet (2016) Smart Cities Plan, Australian Government, Canberra, https://www. infrastructure.gov.au/cities/smart-cities/plan/files/Smart_Cities_Plan.pdf.

Department of the Prime Minister and Cabinet (2017) National Cities Performance Framework Interim Report, Australian Government, Canberra.

Dewilde, C. (2018) 'Explaining the declined affordability of housing for low-income private renters across Western Europe', Urban Studies, vol. 55, no. 12: 2618-2639, doi: 10.1177/0042098017729077.

Doberstein, C. (2011) 'Institutional creation and death: Urban development agreements in Canada', Journal of Urban Affairs, vol. 33, no. 5: 529-548.

Dodson, J. (2004) 'Is there a spatial mismatch between housing affordability and employment opportunity in Melbourne?', Conference on the State of Australian Cities, Parramatta, Urban Frontiers Program, University of Western Sydney, Sydney, NSW.

Dodson, J. (2005) Is there a spatial mismatch between housing affordability and employment opportunity in Melbourne?, AHURI Final Report No. 80, Australian Housing and Urban Research Institute, Melbourne, https://www.ahuri.edu. au/research/final-reports/80.

Dodson, J., de Silva, A., Dalton, T. and Sinclair, S. (2017) Housing, multi-level governance and economic productivity, AHURI Final Report No. 284, Australian Housing and Urban Research Institute Limited, Melbourne, http://www. ahuri.edu.au/research/final-reports/284, doi: 10.18408/ahuri-5307501.

Dodson, J., Li, T. Taylor, E. and Goldie, X. (2020) Commuting burden and housing affordability for low-income renters, AHURI Final Report No. 335, Australian Housing and Urban Research Institute Limited, Melbourne, https://www. ahuri.edu.au/research/final-reports/335, doi: 10.18408/ahuri5320201.

Dodson, J. and Sipe, N. (2007) 'Oil vulnerability in the Australian city: assessing socio-economic risks from higher urban fuel prices', Urban Studies, vol. 44, no. 1: 37-62, doi: 10.1080/00420980601023810.

Dodson, J. and Sipe, N. (2008) 'Shocking the suburbs: urban location, homeownership and oil vulnerability in the Australian city', Housing Studies, vol. 23, no. 3: 377-401, doi: 10.1080/02673030802015619.

Dowling, R., Maalsen, S., Emmanuel, L. and Wolifson, P. (2020) Affordable housing in innovation-led employment strategies, AHURI Final Report No. 333, Australian Housing and Urban Research Institute Limited, Melbourne, https://www. ahuri.edu.au/research/finalreports/333, doi: 10.18408/ahuri-7320401.

Fields, D. (2018) 'Constructing a new asset class: property-led financial accumulation after the crisis', Economic Geography, vol. 94, no. 2: 118-140, doi: 10.1080/00130095.2017.1397492.

Fields, D. and Uffer, S. (2016) 'The financialisation of rental housing: a comparative analysis of New York City and Berlin', Urban Studies, vol. 53, no. 7: 1486-1502, doi: 10.1177/0042098014543704.

Florida, R. (2002) The Rise of the Creative Class, Basic Books, New York, NY.

Forrest, R. and Hirayama, Y. (2015) 'The financialisation of the social project: Embedded liberalism, neoliberalism and home ownership', Urban Studies, vol. 52, no. 2: 233-244, doi: 10.1177/0042098014528394.

Gallez, C. (2014) 'Contrats de développement territorial in the Grand Paris project: towards negotiated networked development?', Town Planning Review, vol. 85, no. 2: 273-286.

Galster, G. (2017) 'People versus place, people and place, or more? New directions for housing policy', Housing Policy Debate, vol. 27, no. 2: 261-265, doi: 10.1080/10511482.2016.1174432.

Glaeser, E. and Gyourko, J. (2018) 'The economic implications of housing supply', Journal of Economic Perspectives, vol. 32, no. 1: 3-30, doi: 10.1257/jep.32.1.3.

Glaeser, E. L. and Gottlieb, J. D. (2009) 'The Wealth of Cities: Agglomeration Economies and Spatial Equilibrium in the United States', Journal of Economic Literature, vol. 47, no. 4: 983-1028, doi: 10.1257/jel.47.4.983.

Glaeser, E. L., Gyourko, J. and Saks, R. E. (2005) 'Urban growth and housing supply', Journal of Economic Geography, vol. 6, no. 1: 71-89.

Glaeser, E. L., Ponzetto, G. A. M. and Tobio, K. (2014) 'Cities, skills and regional change', Regional Studies, vol. 48, no. 1: 7-43, doi: 10.1080/00343404.2012.674637. 
Graham, D. J. (2007) 'Agglomeration, productivity and transport investment', Journal of Transport Economics and Policy, vol. 41, no. 3: 317-343.

Gurran, N., Gilbert, C., Gibb, K., van den Nouwelant, R., James, A. and Phibbs, P. (2018) Supporting affordable housing supply: inclusionary planning in new and renewing communities, AHURI Final Report No. 297, Australian Housing and Urban Research Institute Limited, Melbourne, https://www.ahuri.edu.au/research/final-reports/297, doi: 10.18408/ahuri-7313201.

Gurran, N., Phibbs, P., Yates, J., Gilbert, C., Whitehead, C., Norris, M., McClure, K., Berry, M., Maginn, P., Goodman, R. (2015) Housing markets, economic productivity, and risk: international evidence and policy implications for Australia Volume 1: Outcomes of an Investigative Panel, AHURI Final Report No. 254, Australian Housing and Urban Research Institute Limited, Melbourne, https://www.ahuri.edu.au/research/final-reports/254.

Hulse, K., Milligan, V. and Easthope, H. (2011) Secure occupancy in rental housing: conceptual foundations and comparative perspectives, AHURI Final Report No. 170, Australian Housing and Urban Research Institute Limited, Melbourne, https://www.ahuri.edu.au/research/final-reports/170.

Hulse, K., Parkinson, S. and Martin, C. (2018) Inquiry into the future of the private rental sector, AHURI Final Report No. 303, Australian Housing and Urban Research Institute Limited, Melbourne, https://www.ahuri.edu.au/research/finalreports/303, doi: 10.18408/ahuri-5112001

Hulse, K., Reynolds, M., Nygaard, A., Parkinson, S. and Yates, J. (2019) The supply of affordable private rental housing in Australian cities: short and longer term changes, AHURI Final Report No. 323, Australian Housing and Urban Research Institute Limited, Melbourne, https://www.ahuri.edu.au/research/final-reports/323, doi: 10.18408/ ahuri-5120101

Hulse, K., Reynolds, M., Stone, W. and Yates, J. (2015) Supply shortages and affordability outcomes in the private rental sector: short and longer term trends, AHURI Final Report No. 241, Australian Housing and Urban Research Institute Limited, Melbourne, https://www.ahuri.edu.au/research/final-reports/241.

Hulse, K., Reynolds, M. and Yates, J. (2014) Changes in the supply of affordable housing in the private rental sector for lower income households, 2006-11, AHURI Final Report No. 235, Australian Housing and Urban Research Institute Limited, Melbourne, https://www.ahuri.edu.au/research/final-reports/235.

Hulse, K. and Yates, J. (2017) 'A private rental sector paradox: unpacking the effects of urban restructuring on housing market dynamics', Housing Studies, vol. 32, no. 3: 253-270, doi: 10.1080/02673037.2016.1194378.

Ihlanfeldt, K. R. and Sjoquist, D. L. (1998) 'The spatial mismatch hypothesis: a review of recent studies and their implications for welfare reform', Housing Policy Debate, vol. 9, no. 4: 849-892, doi: 10.1080/10511482.1998.9521321.

Infrastructure Australia (2018) Future Cities: Planning for our Growing Population, Australian Government, Canberra, https://www.infrastructureaustralia.gov.au/publications/future-cities-planning-our-growing-population.

Kain, J. (1968) ‘Housing Segregation, Negro Employment and Metropolitan Decentralization', Quarterly Journal of Economics, vol. 82, no. 2: 175-192, doi: 10.2307/1885893.

Katz, B. and Wagner, J. (2014) The Rise of Innovation Districts: a New Geography of Innovation in America, Brookings Metropolitan Policy Program, Washington DC, https://www.brookings.edu/wp-content/uploads/2016/07/ InnovationDistricts1.pdf.

Kemp, P. A. (2015) 'Private renting after the global financial crisis', Housing Studies, vol. 30, no. 4: 601-620, doi: 10.1080/ 02673037.2015.1027671.

Kurutz, S. (2017) 'Pittsburgh Gets a Tech Makeover', The New York Times, https://www.nytimes.com/2017/07/22/style/ pittsburgh-tech-makeover.html.

Labour Market Research and Analysis Branch (2019) Small Area Labour Markets, Australia, March Quarter 2019, Department of Employment, Skills, Small and Family Business, Canberra.

Lawson, J., Pawson, H., Troy, L., van den Nouwelant, R. and Hamilton, C. (2018) Social housing as infrastructure: an investment pathway, Final Report No. 306, Australian Housing and Urban Research Institute Limited, Melbourne, https://www.ahuri.edu.au/research/final-reports/306.

Li, T., Burke, M. and Dodson, J. (2017) 'Transport impacts of government employment decentralization in an Australian city: testing scenarios using transport simulation', Socio-Economic Planning Sciences, vol. 58: 63-71, doi: 10.1016/ j.seps.2016.10.006. 
Li, T., Dodson, J. and Sipe, N. (2015) 'Exploring Social and Spatial Patterns in Private Vehicle Fuel Efficiency: a case study of Brisbane and Sydney, Australia', Australian Geographer, vol. 46, no. 2: 217-233, doi: 10.1080/00049182.2015.1020994.

$\mathrm{Li}, \mathrm{T}$., Dodson, J. and Sipe, N. (2017) 'Examining household relocation pressures from rising transport and housing costs: an Australian case study', Transport Policy, vol. 65: 106-113, doi: 10.1016/j.tranpol.2017.03.016.

Lyons, G. and Chatterjee, K. (2008) 'A Human Perspective on the daily commute: costs, benefits and trade-offs', Transport Reviews, vol. 28, no. 2: 181-198, doi: 10.1080/01441640701559484.

Ma, L. and Ye, R. (2019) 'Does daily commuting behavior matter to employee productivity?', Journal of Transport Geography, vol. 76: 130-141, doi: 10.1016/j.jtrangeo.2019.03.008.

Maclennan, D., Ong, R. and Wood, G. (2015) Making connections: housing, productivity and economic development, AHURI Final Report No. 251, Australian Housing and Urban Research Institute Limited, Melbourne, https://www. ahuri.edu.au/research/final-reports/251.

Martin, C., Hulse, K., Pawson, H., Hayden, A., Kofner, S., Schwartz, A. and Stephens, M. (2018) The changing institutions of private rental housing: an international review, AHURI Final Report No. 292, Australian Housing and Urban Research Institute Limited, Melbourne, http://www.ahuri.edu.au/research/final-reports/292.

Martin, R., Pike, A., Tyler, P. and Gardiner, B. (2016) 'Spatially rebalancing the UK economy: towards a new policy model?', Regional Studies, vol. 50, no. 2: 342-357, doi: 10.1080/00343404.2015.1118450.

Mattioli, G., Lucas, K. and Marsden, G. (2016) 'The affordability of household transport costs: quantifying the incidence of car-related economic stress in Great Britain', 48th Annual Universities' Transport Study Group Conference, UTSG, Bristol, UK, https://www.researchgate.net/publication/286443267_The_affordability_of_household_transport_costs_ quantifying_the_incidence_of_car-related_economic_stress_in_Great_Britain.

MCU (2010) State of Australian Cities, Major Cities Unit, Infrastructure Australia, Canberra, https://www.infrastructure. gov.au/infrastructure/pab/soac/2010.aspx.

Metz, D. (2008) ‘The myth of travel time saving', Transport Reviews, vol. 28, no. 3: 321-336, doi: 10.1080/01441640701642348.

Milligan, V., Yates, J., Wiesel, I. and Pawson, H. (2013) Financing rental housing through institutional investment-Volume 1, AHURI Final Report No. 202, Australian Housing and Urban Research Institute Limited, Melbourne, https://www. ahuri.edu.au/research/finalreports/202.

Moonen, T. and Clark, G. (2017) The Logic of Innovation Locations: Understanding the drivers that enable cities to host innovation economies, The Business of Cities and Future Cities Catapult, London, UK, https://futurecities.catapult. org.uk/project/logic-innovation-locations/.

Morelix, A., Fairlie, R. W. and Tareque, I. (2017) 2017 Kauffman index of startup activity: metropolitan area and city trends, Ewing Marion Kauffman Foundation, Kansas City, MO, US, https://www.denverpost.com/wp-content/ uploads/2017/05/2017-startup-activity_metro.pdf.

Mullen, C., Marsden, G. and Philips, I. (2020) 'Seeking protection from precarity? Relationships between transport needs and insecurity in housing and employment', Geoforum, vol. 109: 4-13, doi:10.1016/j.geoforum.2019.12.007.

National Housing Supply Council (2014) State of Housing Supply Report: Changes in how we live, The Treasury, Australian Government, Canberra, https://treasury.gov.au/publication/state-of-supply-report-changes-in-how-we-live/.

Nelson, K. P. (1994) 'Whose shortage of affordable housing?', Housing Policy Debate, vol. 5, no. 4: 401-442, doi:10.1080/ 10511482.1994.9521172.

Nelson, K. P. (2002) 'Housing needs and effective policies in high $\square$ tech metropolitan economies', Housing Policy Debate, vol. 13, no. 2: 417-468, doi: 10.1080/10511482.2002.9521449.

Neumark, D. and Simpson, H. (2015) 'Place-based policies', in G. Duranton, J. V. Henderson and W. Strange (eds), Handbook of Regional and Urban Economics, vol. 5: 1197-1287, Elsevier, https://econpapers.repec.org/bookchap/eeeregchp/ 5-1197.htm.

Newman, S. J. (2019) 'Affordable Rental Housing Policy', Housing Policy Debate, vol. 29, no. 1: 22-24, doi:10.1080/10511482. 2018.1506393.

O'Brien, P. and Pike, A. (2015) 'City deals, decentralisation and the governance of local infrastructure funding and financing in the UK', National Institute Economic Review, vol. 233, no. 1: R14-R26, doi:10.1177/002795011523300103. 
OECD (2011) 'Housing and the Economy: Policies for renovation', in Economic Policy Reforms 2011: Going for Growth, OECD, Paris, http://www.oecd.org/economy/growth/46901936.pdf.

Ong, R., Dalton, T., Gurran, N., Phelps, C., Rowley, S. and Wood, G. A. (2017) Housing supply responsiveness in Australia: distribution, drivers and institutional settings, AHURI Final Report No. 281, Australian Housing and Urban Research Institute Limited, Melbourne, https://www.ahuri.edu.au/research/final-reports/281, doi: 10.18408/ahuri-8107301.

Ong, R., Wood, G. A., Whelan, S., Cigdem-Bayram, M., Atalay, K. and Dodson, J. (2017) Inquiry into housing policies, labour force participation and economic growth, AHURI Final Report No. 285, Australian Housing and Urban Research Institute Limited, Melbourne, https://www.ahuri.edu.au/research/final-reports/285, doi: 10.18408/ahuri-8107001.

Palm, M., and Niemeier, D. (2017) 'Achieving regional housing planning objectives: directing affordable housing to jobs-rich neighborhoods in the San Francisco Bay Area', Journal of the American Planning Association, vol. 83, no. 4: 377-388, doi: 10.1080/01944363.2017.1368410.

Peng, Z. R. (1997) 'The jobs-housing balance and urban commuting', Urban Studies, vol. 34, no. 8: 1215-1235, doi: 10.1080/ 0042098975600.

Pill, M., Gurran, N. and Gilbert, C. (2020) 'Strategic planning, "City Deals" and affordable housing', AHURI Final Report No. 331, Australian Housing and Urban Research Institute Limited, Melbourne, https://www.ahuri.edu.au/research/ final-reports/331, doi: 10.18408/ahuri-7320301.

Productivity Commission (2015) Housing Assistance and Employment in Australia, Commission Research Paper, Australian Government, Canberra, https://www.pc.gov.au/research/completed/housing-employment.

Productivity Commission (2019) Vulnerable Private Renters: Evidence and Options, Commission Research Paper, Australian Government, Canberra, https://www.pc.gov.au/research/completed/renters.

Puga, D. (2010) 'The magnitude and causes of agglomeration economies', Journal of Regional Science, vol. 50, no. 1: 203-219, doi: 10.1111/j.1467-9787.2009.00657.x.

Quercia, R. G., Stegman, M. A. and Davis, W. R. (2002) 'Does a highDtech boom worsen housing problems for working families?' Housing Policy Debate, vol. 13, no. 2: 393-415, doi: 10.1080/10511482.2002.9521448.

Rohe, W. M. and Galster, G. C. (2014) 'The Community Development Block Grant Program turns 40: proposals for program expansion and reform', Housing Policy Debate, vol. 24, no. 1: 3-13, doi:10.1080/10511482.2013.865973.

Ronald, R. and Kadi, J. (2018) 'The revival of private landlords in Britain's post-homeownership society', New Political Economy, vol. 23, no. 6: 786-803, doi: 10.1080/13563467.2017.1401055.

Ronald, R., Lennartz, C. and Kadi, J. (2017) 'What ever happened to asset-based welfare? Shifting approaches to housing wealth and welfare security', Policy \& Politics, vol. 45, no. 2: 173-193, doi: 10.1332/030557316X14786045239560.

Rosenthal, S. S. and Strange, W. C. (2004) 'Evidence on the nature and sources of agglomeration economies', in J. V. Henderson and J. Thisse (eds), Handbook of Regional and Urban Economics, vol. 4: 2119-2171, Elsevier, https://econpapers.repec.org/bookchap/eeeregchp/4-49.htm.

Saiz, A. (2010) ‘The geographic determinants of housing supply', Quarterly Journal of Economics, vol. 125, no. 3: 1253-1296, doi: 10.1162/qjec.2010.125.3.1253.

Sandford, M. (2018) Briefing Paper Number 07029: Devolution to local government in England, UK Parliament, London.

Saugeres, L. and Hulse, K. (2010) Public housing, women and employment: challenges and strategies, AHURI Final Report No. 155, Australian Housing and Urban Research Institute Limited, Melbourne, https://www.ahuri.edu.au/research/ final-reports/155.

SGS. (2019). Economic performance of Australia's cities and regions. Melbourne: SGS Economics and Planning Py Ltd

Startup Muster (2018) Startup Muster Annual Report, University of Technology Sydney (UTS), https://neweconomy.media/ wp-content/uploads/2019/06/Startup-Muster-2018-Report.pdf.

Stutzer, A. and Frey, B. S. (2008) 'Stress that doesn't pay: the commuting paradox', Scandinavian Journal of Economics, vol. 110, no. 2: 339-366, doi: 10.1111/j.1467-9442.2008.00542.x.

Troy, P. (2012) Accommodating Australians; Commonwealth Government Involvement in Housing, The Federation Press, Sydney.

Urbis. (2013). Broader Western Sydney Employment Area Economic Issues and Drivers Study. Sydney: Urbis. 
van den Nouwelant, R., Crommelin, L., Herath, S. and Randolph, B. (2016) Housing affordability, central city economic, productivity and the lower income labour market, AHURI Final Report No. 261, Australian Housing and Urban Research Institute Limited, Melbourne, https://www.ahuri.edu.au/research/final-reports/261.

van Ommeren, J. N. and Gutiérrez-i-Puigarnau, E. (2011) 'Are workers with a long commute less productive? An empirical analysis of absenteeism', Regional Science and Urban Economics, vol. 41, no. 1: 1-8, doi: 10.1016/j.regsciurbeco. 2010.07.005.

Vandenbroucke, D. A. (2007) 'Is there enough housing to go around?', Cityscape, vol. 9, no. 1: 175-188, https://www. huduser.gov/periodicals/cityscpe/vol9num1/ch8.pdf.

Weisbrod, G., Vary, D. and Treyz, G. (2003) 'Measuring Economic Costs of Urban Traffic Congestion to Business', Transportation Research Record: Journal of the Transportation Research Board, vol. 1,839, no. 1: 98-106, doi: 10.3141/1839-10.

Welch, T. F. (2013) 'Equity in transport: the distribution of transit access and connectivity among affordable housing units', Transport Policy, vol. 30: 283-293, doi: 10.1016/j.tranpol.2013.09.020.

Whelan, S. and Parkinson, S. (2017) 'Housing tenure, mobility and labour market behaviour', AHURI Final Report No. 280, Australian Housing and Urban Research Institute Limited, Melbourne, https://www.ahuri.edu.au/research/finalreports/280, doi: 10.18408/ahuri-7307101.

Whitehead, C., Monk, S., Scanlon, K., Makkanen, S. and Tang, C. (2012) The Private Rented Sector in the New Century: a Comparative Approach, Cambridge Centre for Housing and Planning Research, Cambridge, UK.

Wulff, M., Reynolds, M., Dharmalingam, A., Hulse, K. and Yates, J. (2011) Australia's private rental market: the supply of, and demand for, affordable dwellings, AHURI Final Report No. 168, Australian Housing and Urban Research Institute, Melbourne, https://www.ahuri.edu.au/research/final-reports/168.

Wulff, M. and Yates, J. (2001) Low rent housing in Australia, 1986-1996. How has it changed, who does it work for and who does it fail?, Australian Housing Research Fund Project No. 213, Department of Family and Community Services, Canberra.

Zapata, M. A. and Bates, L. K. (2017) 'Equity planning or equitable opportunities? The construction of equity in the HUD sustainable communities regional planning grants', Journal of Planning Education and Research, vol. 37, no. 4: 411-424, doi: 10.1177/0739456X16657874.

Zheng, X.-P. (2001) 'Determinants of agglomeration economies and diseconomies: empirical evidence from Tokyo', SocioEconomic Planning Sciences, vol. 35, no. 2: 131-144, doi: 10.1016/S0038-0121(00)00008-2. 


\section{AHURi}

Australian Housing and Urban Research Institute Level 12, 460 Bourke Street

Melbourne VIC 3000

\section{Australia}

+61396602300

information@ahuri.edu.au

ahuri.edu.au

(?) twitter.com/AHURI_Research

f facebook.com/AHURI.AUS

in Australian Housing and Urban Research Institute 